\title{
Simulation of tropospheric chemistry and aerosols with the climate model EC-Earth
}

\author{
T. P. C. van Noije $^{1}$, P. Le Sager ${ }^{1}$, A. J. Segers ${ }^{2}$, P. F. J. van Velthoven ${ }^{1}$, M. C. Krol ${ }^{3,4}$, W. Hazeleger ${ }^{1,3}$, A. G. Williams ${ }^{5}$, \\ and S. D. Chambers ${ }^{5}$ \\ ${ }^{1}$ Royal Netherlands Meteorological Institute, De Bilt, the Netherlands \\ ${ }^{2}$ Netherlands Organisation for Applied Scientific Research (TNO), Utrecht, the Netherlands \\ ${ }^{3}$ Wageningen University, Wageningen, the Netherlands \\ ${ }^{4}$ Institute for Marine and Atmospheric Research Utrecht, Utrecht University, Utrecht, the Netherlands \\ ${ }^{5}$ Institute for Environmental Research, Australian Nuclear Science and Technology Organisation, Lucas Heights, Australia
}

Correspondence to: T. P. C. van Noije (noije@knmi.nl)

Received: 20 February 2014 - Published in Geosci. Model Dev. Discuss.: 25 March 2014

Revised: 1 September 2014 - Accepted: 15 September 2014 - Published: 22 October 2014

\begin{abstract}
We have integrated the atmospheric chemistry and transport model TM5 into the global climate model EC-Earth version 2.4. We present an overview of the TM5 model and the two-way data exchange between TM5 and the IFS model from the European Centre for Medium-Range Weather Forecasts (ECMWF), the atmospheric general circulation model of EC-Earth. In this paper we evaluate the simulation of tropospheric chemistry and aerosols in a oneway coupled configuration. We have carried out a decadal simulation for present-day conditions and calculated chemical budgets and climatologies of tracer concentrations and aerosol optical depth. For comparison we have also performed offline simulations driven by meteorological fields from ECMWF's ERA-Interim reanalysis and output from the EC-Earth model itself. Compared to the offline simulations, the online-coupled system produces more efficient vertical mixing in the troposphere, which reflects an improvement of the treatment of cumulus convection. The chemistry in the EC-Earth simulations is affected by the fact that the current version of EC-Earth produces a cold bias with too dry air in large parts of the troposphere. Compared to the ERA-Interim driven simulation, the oxidizing capacity in EC-Earth is lower in the tropics and higher in the extratropics. The atmospheric lifetime of methane in EC-Earth is 9.4 years, which is $7 \%$ longer than the lifetime obtained with ERA-Interim but remains well within the range reported in the literature. We further evaluate the model by comparing the simulated climatologies of surface radon-222 and carbon
\end{abstract}

monoxide, tropospheric and surface ozone, and aerosol optical depth against observational data. The work presented in this study is the first step in the development of EC-Earth into an Earth system model with fully interactive atmospheric chemistry and aerosols.

\section{Introduction}

Chemically reactive gases and aerosols play important roles in the climate system. They affect the Earth's energy balance by direct interaction with radiation and in various indirect ways.

Ozone $\left(\mathrm{O}_{3}\right)$ absorbs both solar (shortwave) and terrestrial (longwave) radiation. The absorption of ultraviolet and visible radiation by ozone causes solar heating in the stratosphere, and the absorption of thermal infrared radiation makes ozone an important greenhouse gas.

Depletion of stratospheric ozone has been the main cause for the observed cooling of the lower stratosphere since the 1980s (Forster et al., 2011). Although the impact on the global radiation balance of the troposphere is thought to be relatively small (Myhre et al., 2013b), stratospheric ozone depletion has been identified as an important driver of tropospheric circulation changes in the Southern Hemisphere (e.g. Gillett and Thompson, 2003; Arblaster and Meehl, 2006; Polvani et al., 2011) and of circulation changes in the Southern Ocean (Sigmond et al., 2011). This may also have 
reduced the uptake of carbon dioxide $\left(\mathrm{CO}_{2}\right)$ by the Southern Ocean (Lenton et al., 2009). It is anticipated that the expected recovery of the ozone layer in the coming decades will tend to reverse these trends (Perlwitz et al., 2008; Son et al., 2008; Sigmond et al., 2011).

Ozone is not directly emitted into the atmosphere. In the troposphere it is produced by oxidation of carbon monoxide $(\mathrm{CO})$, methane $\left(\mathrm{CH}_{4}\right)$, and other volatile organic compounds (VOCs), in the presence of nitrogen oxides $\left(\mathrm{NO}_{\mathrm{x}}=\mathrm{NO}+\mathrm{NO}_{2}\right)$. Increases in tropospheric ozone since the preindustrial era have contributed substantially to global warming by direct radiative effects (Stevenson et al., 2013; Myhre et al., 2013b), especially in the Northern Hemisphere (Mickley et al., 2004; Shindell et al., 2006a). Moreover, increases in ground-level ozone may have contributed to global warming by reducing the $\mathrm{CO}_{2}$ uptake by vegetation (Felzer et al., 2005; Sitch et al., 2007; Arneth et al., 2013), but the importance of this effect is still uncertain (Myhre et al., 2013b).

Methane itself strongly absorbs thermal infrared radiation and is therefore a very potent greenhouse gas. Methane is also important as a precursor of stratospheric water vapour. Increases in methane concentrations have contributed substantially to global warming, and increases in the anthropogenic methane emissions even more so (Shindell et al., 2009; Myhre et al., 2013b).

Aerosols affect the Earth's radiation budget by scattering and absorption of sunlight, by absorption of thermal infrared radiation, and by interactions with clouds. Scattering tends to increase the planetary albedo and has a cooling effect. Absorption, on the other hand, causes warming in the atmosphere. The importance of scattering versus absorption depends on the chemical composition, mixing state, size distribution, particle shapes, and vertical distribution of the aerosol mixture, as well as on the presence of clouds and the surface albedo.

Absorption of infrared radiation mainly takes place through coarse-mode aerosols, and is most relevant for stratospheric aerosols resulting from large volcanic eruptions (Arfeuille et al., 2013), and for tropospheric aerosols containing mineral dust or sea salt (Jacobson, 2001). The shortwave radiative effects of aerosols are generally considered to be more important for the climate (Myhre et al., 2013a, b).

Black carbon (Petzold et al., 2013) strongly absorbs sunlight, which makes it an important warming agent (Bond et al., 2013). Sulfate, nitrate, and sea salt only weakly absorb sunlight and are mainly scattering. Mineral dust and organic aerosols vary from weakly to strongly absorbing, depending on their composition and the wavelength of the light. Light absorbing aerosols such as black carbon and mineral dust also have a warming effect when deposited on snow or ice (Myhre et al., 2013b).

Aerosol-cloud interactions include the effects of aerosols on the albedo and the lifetime of clouds (Boucher et al., 2013). Overall, aerosol-cloud interactions are thought to have a cooling effect (Myhre et al., 2013b).
Due to the difficulty of characterizing the concentrations and properties of aerosols and the complexities involved in the processes that determine their effects on the climate, aerosols still are a major source of uncertainty in our understanding of climate change. It is generally believed that increases in anthropogenic aerosols since the preindustrial era have slowed down global warming, but it is highly uncertain by how much (Myhre et al., 2013b). Moreover, the cooling effect of increases in sulfate and other weakly absorbing aerosols, such as organic aerosols and nitrate, has been largely compensated by a substantial warming effect due to increases in black carbon (Bond et al., 2013).

Aerosols and chemically reactive gases are coupled in various ways. Many aerosol components are produced from gaseous precursors by chemical reactions and nucleation or condensation processes in the atmosphere. Sulfate $\left(\mathrm{SO}_{4}\right)$, nitrate $\left(\mathrm{NO}_{3}\right)$ and ammonium $\left(\mathrm{NH}_{4}\right)$ result from emissions of sulfur dioxide $\left(\mathrm{SO}_{2}\right)$, dimethyl sulfide (DMS), $\mathrm{NO}_{\mathrm{x}}$, and ammonia $\left(\mathrm{NH}_{3}\right)$, and secondary organic aerosols ( $\mathrm{SOA}$ ) from emissions of VOCs. Nitrate, ammonium and many organic aerosol components are semi-volatile and exist in equilibrium with their gas-phase counterparts. Moreover, aerosols have an influence on photolysis rates by scattering and absorption of ultraviolet light and by their impacts on clouds. They also provide particle surfaces on which heterogeneous chemical reactions can take place.

Deposition of chemically reactive gases and aerosols from the atmosphere is a source of nutrients to the terrestrial and marine biosphere. The biogeochemical cycles of nitrogen and carbon are tightly coupled, and it is likely that the availability of reactive nitrogen will be a limiting factor for the land carbon sink in the twenty-first century (Ciais et al., 2013).

Despite the important role aerosols and chemically reactive gases play in the climate system, the description of atmospheric chemistry and aerosols varies strongly among climate models. Most global models that participated in the recent Coupled Model Intercomparison Project Phase 5 (CMIP5) (Taylor et al., 2012) did not include atmospheric chemistry and many did not have fully interactive aerosols (Flato et al., 2013). Even so, atmospheric or atmosphereocean general circulation models (GCMs) are increasingly being transformed into chemistry-climate models (CCMs) with interactive representations of chemistry and aerosols (e.g. Zhang, 2008; Dameris and Jöckel, 2013; Lamarque et al., 2012).

The work presented in this paper is the first step in the development of an interactive chemistry module in the global climate model EC-Earth (Hazeleger et al., 2010, 2012). EC-Earth is a relatively new climate model that has been developed in recent years by a consortium of partner institutes from currently ten European countries, consisting of the national meteorological services of Denmark, Ireland, the Netherlands, Portugal, Spain and Sweden, universities, high-performance computing centres, and other 
research institutes. The atmospheric GCM of EC-Earth is based on the Integrated Forecasting System (IFS) model from the European Centre for Medium-Range Weather Forecasts (ECMWF). EC-Earth is used for seasonal to decadal predictions as well as for long-term climate simulations (see Hazeleger et al., 2010).

The chemistry module of EC-Earth is based on the chemistry and transport model TM5 (Krol et al., 2005; Huijnen et al., 2010; Aan de Brugh et al., 2011). We have integrated TM5 into EC-Earth by coupling it online to IFS. The model allows for two-way exchange of fields between TM5 and IFS, but in this paper we focus on the impact of the online integration on the performance of TM5, without feedbacks to IFS.

To this end, we have carried out a decadal simulation of tropospheric chemistry and aerosols for present-day conditions, and calculated seasonal climatologies of concentration fields and chemical budgets for various tracers. For comparison, we have repeated this simulation with the stand-alone version of TM5 driven by meteorological fields from the ECMWF ERA-Interim reanalysis (Dee et al., 2011). We have evaluated the results from both simulations against a number of observational data sets.

In Sect. 2 we briefly introduce the EC-Earth model and describe the most important aspects of TM5 and the data exchange between TM5 and IFS. In Sect. 3 we describe the set-up of the online and offline simulations. An evaluation of the results is presented in Sect. 4. We end with a discussion and conclusions in Sect. 5.

\section{Model description}

\section{$2.1 \quad$ EC-Earth version 2.3}

The atmosphere-ocean GCM applied in this study is ECEarth version 2.3. It consists of an atmospheric GCM based on the IFS model cycle $31 \mathrm{r} 1$ with the H-TESSEL landsurface scheme, and an ocean GCM from the Nucleus for European Modelling of the Ocean (NEMO) version 2 with the Louvain-la-Neuve sea ice model (LIM) version 2. The exchange of two-dimensional fields between IFS-H-TESSEL and NEMO-LIM takes place through the OASIS3 coupler (Ocean Atmosphere Sea Ice Soil version 3). A description of these components and the coupling interface is given by Hazeleger et al. (2010, 2012).

A number of improvements in physical parameterizations have been included from more recent cycles of IFS (see Hazeleger et al., 2012). In particular, the convection scheme has been updated to the formulation of cycle $32 \mathrm{r} 3$. A detailed description of the changes that are involved in this update is given by Bechtold et al. (2008). It has been shown that the new convection scheme produces higher and more realistic levels of convective activity over land, and leads to improvements in tropical precipitation patterns and extratropical circulation characteristics (Bechtold et al., 2008; Jung et al., 2010).

EC-Earth version 2.3 has been used for CMIP5. Compared to the version described by Hazeleger et al. (2012), the aerosol forcings have been improved and made consistent with the CMIP5 recommendations (Taylor et al., 2012). In this study, we applied the same configuration as for the CMIP5 long-term simulations, using the T159 spectral resolution (corresponding to $1.125^{\circ}$ ) with 62 vertical levels for the atmosphere and the ORCA 1 grid (about $1^{\circ}$ horizontal resolution and 42 layers) for the ocean.

\subsection{TM5}

We have extended the atmosphere-ocean GCM version of EC-Earth with a module for simulating atmospheric chemistry and transport, the Tracer Model 5 (TM5). The new model configuration with TM5 has been released as part of EC-Earth version 2.4. TM5 can be used for non-reactive greenhouse gases like $\mathrm{CO}_{2}$ (Peters et al., 2010) and sulfur hexafluoride $\left(\mathrm{SF}_{6}\right)$ (Peters et al., 2004), for diagnostic radioactive tracers like radon-222 $\left({ }^{222} \mathrm{Rn}\right)$ and lead-210 $\left({ }^{210} \mathrm{~Pb}\right)$, as well as for chemically reactive gases and aerosols. The version used in this study is based on the tropospheric chemistry version documented by Huijnen et al. (2010), extended with the aerosol microphysics and optics modules described by Aan de Brugh et al. (2011) and Aan de Brugh (2013). In this section we will give an overview of the main characteristics of this TM5 model version and briefly describe the most important modifications and improvements compared to these earlier publications.

\subsubsection{Resolution}

The global atmospheric domain of TM5 is discretized on a regular latitude-longitude grid. To limit the computational costs, this grid will typically have a coarser resolution than the grid used in IFS. In this study a horizontal resolution of $3^{\circ} \times 2^{\circ}$ (longitude $\times$ latitude) is used. Zoom regions with higher horizontal resolutions can be defined and nested into the global domain (Krol et al., 2005), but this option is not used in EC-Earth. To avoid the use of very short time steps near the poles, the number of grid cells in the zonal direction is gradually reduced in the polar regions. Dry deposition velocities and surface emission fluxes that depend on local meteorological conditions and/or other surface variables are calculated on a higher-resolution surface grid and subsequently coarsened to the atmospheric grid. The resolution of the surface grid is currently $1^{\circ} \times 1^{\circ}$.

In the vertical direction TM5 uses the same hybrid sigmapressure levels as used in the IFS model version to which it is coupled, or a subset thereof. In the EC-Earth configuration applied in this study a selection of 31 levels is made out of the 62 levels used in IFS. Because of the relatively poor vertical resolution of the 62-level version of IFS in the upper part of 
the domain (e.g. compared to the 60- or 91-level versions), no merging of levels is applied above $\sim 100 \mathrm{hPa}$. The top of the model is at $5 \mathrm{hPa}$.

\subsubsection{Data exchange and transformations}

As for the exchange between IFS and NEMO, the data exchange between IFS and TM5 takes place through OASIS3 (Valcke, 2013). To prevent the different components having to wait for each other, IFS runs one exchange time interval ahead of the other modules. In the current configuration, the interval for the data exchange between TM5 and IFS is set to $6 \mathrm{~h}$. A more frequent exchange will be applied in future versions of the model.

Since OASIS3 can only deal with two-dimensional (2-D) fields, three-dimensional (3-D) fields are transferred layer by layer. The layers that are transferred from IFS to TM5 and vice versa correspond to the full vertical resolution of IFS. The required merging of the layers and interpolation of the data in the vertical direction is performed on the TM5 side.

TM5 receives both meteorological data and surface property fields from IFS. The data sets employed in the chemistry version of TM5 used in this study are listed in Table 1. They include instantaneous, time-averaged, and constant fields.

Most fields are interpolated by OASIS to TM5's regular latitude-longitude atmospheric or higher-resolution surface grid. However, to avoid unnecessary interpolations of the wind fields, the wind divergence and vorticity fields and the concurrent surface pressure field are received in their native spectral representation and transformed into gridded air mass fluxes following the procedure of Segers et al. (2002). Here the vertical mass fluxes are calculated directly from the spectral fields, and the local mass balance over the exchange interval is closed by slightly adjusting the horizontal mass fluxes. This method has been shown to lead to superior chemistry simulations compared to methods that make use of interpolated wind fields (Bregman et al., 2003).

Most instantaneous fields transferred from IFS to TM5, including the spectral fields mentioned above, are valid for the middle of the exchange interval. However, for closing the mass balance the surface pressure is also required at the beginning and at the end of the interval. This is achieved by reading the initial surface pressure field from the TM5 restart file, and including an additional (gridded) surface pressure field valid for the end of the interval in the transfer.

The system has also been prepared for data transfer in the other direction. The fields that can currently be transferred from TM5 to IFS are the ozone and methane concentrations, the particle number and component-specific mass concentrations in the different aerosol modes (see below), and aerosol optical property fields (extinction, single-scattering albedo and asymmetry factor) at the wavelengths used in the IFS shortwave radiation scheme. Because IFS runs ahead of TM5, these forcing fields are applied with some delay in IFS. To minimize this delay, they are treated as instantaneous fields calculated at the end of the exchange interval. This reduces the delay to half an exchange time step on average.

In this paper we first evaluate the one-way coupled simulation of chemistry and aerosols. In a forthcoming publication two-way coupling will be applied, including feedbacks of the TM5 forcing fields to the radiation and cloud scheme of IFS.

\subsubsection{Transport}

Tracers in TM5 are moved around by advection, cumulus convection, and vertical diffusion. Tracer advection is described using either the first-order moments (slopes) algorithm developed by Russell and Lerner (1981) or the secondorder moments scheme by Prather (1986). Both schemes are conserving the mass of the advected tracers. This is an important requirement especially for chemistry-climate simulations, where the tracer concentrations are not constrained by assimilation. The default option is to use the slopes scheme, which is used in the simulations presented in this study.

Convective tracer transport in TM5 is described using a bulk mass flux approach, in which clouds are represented by a single pair of entraining and detraining plumes describing the updraft and downdraft motions. The meteorological fields involved in the calculation are the vertical air mass fluxes and the entrainment and detrainment rates in the updrafts and downdrafts. In EC-Earth the mass fluxes and detrainment rates are taken from IFS. The corresponding entrainment rates follow from mass conservation. Thus, the description of convective tracer transport in TM5 is fully consistent with the representation of convection in IFS.

Vertical diffusion of tracers in TM5 is described with a first-order closure scheme, where the diffusion coefficient is assumed to be the same as for heat (Olivié et al., 2004a). In the free troposphere it is computed based on wind shear and static stability following Louis (1979). In the boundary layer it is based on the revised Louis-Tiedtke-Geleyn (LTG) scheme of Holtslag and Boville (1993). The boundary layer height is calculated following Vogelezang and Holtslag (1996). Details are given in Olivié et al. (2004a).

\subsubsection{Chemistry}

The TM5 version applied in this study is designed to simulate the concentrations of reactive gases and aerosols in the troposphere and their deposition to the Earth's surface. The model's gas-phase, aqueous-phase, and heterogeneous chemistry schemes are described by Huijnen et al. (2010). Details on the aqueous-phase chemistry can be found in Roelofs (1992) and Feichter et al. (1996).

The gas-phase reaction scheme, representing the oxidation of $\mathrm{CO}, \mathrm{CH}_{4}$, and non-methane volatile organic compounds (NMVOCs) in the presence of $\mathrm{NO}_{\mathrm{x}}$, is based on the Carbon Bond Mechanism 4 (CBM4). It utilizes a structural-lumping technique in which organic species are grouped into one or more surrogate categories according to the carbon bond types 
Table 1. Meteorological data and surface property fields transferred from IFS to TM5.

\begin{tabular}{ll}
\hline Field & Type \\
\hline Three-dimensional & \\
\hline Wind divergence/vorticity & Instantaneous \\
Temperature & Instantaneous \\
Specific humidity & Instantaneous \\
Cloud liquid/ice water content & Instantaneous \\
Cloud fraction & Instantaneous \\
Overhead/underfoot cloud fraction & Instantaneous \\
Updraught/downdraught convective air mass flux & Average \\
Updraught/downdraught convective air mass detrainment rate & Average \\
\hline Two-dimensional & \\
\hline Surface pressure & Instantaneous \\
10 m wind (west-east/south-north components) & Instantaneous \\
2 m temperature & Instantaneous \\
2 m dew point temperature & Instantaneous \\
Surface east-west/north-south momentum stress & Average \\
Surface sensible/latent heat flux & Average \\
Surface solar radiation & Average \\
Stratiform precipitation as rain & Average \\
Convective precipitation as rain & Average \\
Skin reservoir water content & Instantaneous \\
Snow depth & Instantaneous \\
Soil wetness in top soil layer & Instantaneous \\
Low/high vegetation cover fractions & Instantaneous \\
Vegetation type fractions & Instantaneous \\
Surface roughness & Instantaneous \\
Surface orography & Constant \\
Land/sea fraction & Constant \\
Sea-ice fraction & Instantaneous \\
\hline & \\
\hline & \\
\hline
\end{tabular}

present in the molecule. CBM4 was originally developed for simulating urban and regional photochemistry (Gery et al., 1989), and was later extended to the global scale by including reactions important under background conditions (Houweling et al., 1998). Since then, reaction rates and product distributions have been updated (see Huijnen et al., 2010). In addition to CBM4, the gas-phase chemistry scheme in TM5 also includes reactions for the oxidation of $\mathrm{SO}_{2}, \mathrm{DMS}$, and $\mathrm{NH}_{3}$.

Photolysis rates are calculated based on the parameterization of Landgraf and Crutzen (1998), using seven wavelength bands between 202.0 and $752.5 \mathrm{~nm}$. Variations due to the effects of clouds, overhead ozone, and surface albedo are included following Krol and van Weele (1997).

Aqueous-phase chemistry in clouds is included for the oxidation of total dissolved sulfur dioxide, S(IV), by dissolved hydrogen peroxide $\left(\mathrm{H}_{2} \mathrm{O}_{2}\right)$ and $\mathrm{O}_{3}$, depending on the acidity of the droplets. The sulfate production rates due to the oxidation of $\mathrm{S}(\mathrm{IV})$ by $\mathrm{H}_{2} \mathrm{O}_{2}$ and $\mathrm{O}_{3}$ are calculated following Martin and Damschen (1981), with a temperature dependence from Nair and Peters (1989), and Maahs (1983), respectively. The representation of heterogeneous chemistry is currently limited to the reactive uptake of dinitrogen pentoxide $\left(\mathrm{N}_{2} \mathrm{O}_{5}\right)$ at the surface of cloud droplets, cirrus particles, and aerosols, which produces nitric acid $\left(\mathrm{HNO}_{3}\right)$ (Dentener and Crutzen, 1993).

\subsubsection{Aerosols}

Aerosols are represented in the model as described by Aan de Brugh et al. (2011). Sulfate, black carbon (BC), organic carbon (OC), sea salt and mineral dust are described with the size-resolved modal microphysics scheme M7 (Vignati et al., 2004). It uses seven log-normal size distributions or modes with predefined geometric standard deviations. There are four water-soluble modes (nucleation, Aitken, accumulation, and coarse) and three insoluble modes (Aitken, accumulation and coarse). The nucleation mode contains only $\mathrm{SO}_{4}$ particles with dry diameters smaller than $10 \mathrm{~nm}$. The Aitken, accumulation, and coarse modes represent particles with dry diameters in the range $10-100 \mathrm{~nm}, 100 \mathrm{~nm}-1 \mu \mathrm{m}$, and larger than $1 \mu \mathrm{m}$, respectively. The insoluble Aitken mode consists of internally mixed particles of $\mathrm{BC}$ and $\mathrm{OC}$, while the larger insoluble modes contain only dust particles. The soluble 
Aitken mode represents internal mixtures of sulfate, $\mathrm{BC}$, and $\mathrm{OC}$, while the larger soluble modes also contain sea salt and dust in the mixture. Each mode is characterized by the total particle number and the mass of each component. With this the total number of aerosol tracers in M7 amounts to 25. The microphysical processes included in $\mathrm{M} 7$ are the formation of new $\mathrm{SO}_{4}$ particles by nucleation from gaseous sulfuric acid $\left(\mathrm{H}_{2} \mathrm{SO}_{4}\right)$, condensation of $\mathrm{H}_{2} \mathrm{SO}_{4}$ onto existing particles, water uptake, and intramodal and intermodal coagulation.

Of organic aerosols (OA), also known as particulate organic matter (POM), only the carbon component is included in M7. To account for the other components that may be present, in TM5 the dry mass of organic aerosols is assumed to be $40 \%$ higher than the OC mass (e.g. Dentener et al., 2006; Kinne et al., 2006).

The current chemistry scheme does not describe the formation of secondary organic aerosols. An additional source of organic aerosols is therefore included near the surface over land, representing SOA formation from biogenic NMVOCs (mainly mono-terpenes) on timescales of a few hours. The total mass of SOA being formed is prescribed using monthly fields from Dentener et al. (2006), which amount to $19.1 \mathrm{Tg}$ POM year ${ }^{-1}$. The freshly formed SOA particles are assumed soluble and are added to the soluble Aitken mode, as in Aan de Brugh et al. (2011).

The other aerosol components included in the model are nitrate, ammonium, and methane sulfonic acid (MSA), which is produced in the oxidation of DMS. These are represented by their total mass, i.e. using a bulk aerosol approach. The gas-aerosol partitioning of the semi-volatile inorganic species (i.e. the ratios between $\mathrm{HNO}_{3}$ and nitrate aerosol and between $\mathrm{NH}_{3}$ and $\mathrm{NH}_{4}$ ) is described with the thermodynamic equilibrium model EQSAM (Metzger et al., 2002).

The optical properties of the aerosol mixtures are calculated as a function of wavelength based on Mie theory, using a look-up table (Aan de Brugh et al., 2011; Aan de Brugh, 2013). The optical effects of nitrate aerosol are included by assuming that the ammonium nitrate and the water absorbed by it are present in the soluble accumulation mode (Aan de Brugh et al., 2011). Effective-medium approximations are applied to calculate the refractive indices of the internally mixed modes. Sulfate, nitrate, OC, sea salt, and water are treated as homogeneous mixtures described by the Bruggeman mixing rule. When $\mathrm{BC}$ and/or dust are present in the mix, these are treated as inclusions in a homogeneous background medium, using the Maxwell-Garnett mixing rule. A more detailed description of the optics module of TM5 is given by Aan de Brugh (2013).

\subsubsection{Radioactive tracers}

In addition to reactive gases and aerosols, the model also includes the diagnostic radioactive tracers radon-222 and lead210. Radon-222 is chemically inert and insoluble in water. It is emitted at a relatively uniform rate from the continental crust and decays with a half-life of 3.8 days into lead-210. Because of its short lifetime, radon-222 can be used to study rapid vertical exchange from the continental boundary layer to the free troposphere and further transport to more remote parts of the atmosphere (see reviews in Zahorowski et al., 2004; Williams et al., 2011). Lead-210 has a much longer half-life (22.3 years). After being formed, it rapidly attaches to submicron aerosol particles. As a consequence, lead-210 is mainly removed from the atmosphere by wet deposition and can be used to diagnose the wet scavenging processes in the model.

\subsubsection{Dry and wet deposition}

Dry deposition of gases and aerosols to the Earth's surface in TM5 is described using a standard resistance approach (e.g. Seinfeld and Pandis, 2006). Dry deposition velocities of gaseous species are calculated as the inverse of the sum of an aerodynamic resistance, a quasi-laminar sublayer resistance and a surface resistance. The surface resistance is calculated following the method of Wesely (1989), which distinguishes between deposition to vegetation, bare soils, water or wet surfaces, and snow or ice, and combines the various deposition pathways into a total surface resistance. The gas-phase deposition scheme is described in more detail by Ganzeveld and Lelieveld (1995) and Ganzeveld et al. (1998). An overview is given in Huijnen et al. (2010).

Dry deposition velocities of aerosols are determined by the aerodynamic resistance and a quasi-laminar sublayer resistance, enhanced by sedimentation of particles by gravitational settling. The quasi-laminar sublayer resistance depends on particle size and is calculated for land and sea surfaces following Slinn (1976) and Slinn and Slinn (1980), respectively. The implementation for the M7 modes is described by Aan de Brugh et al. (2011).

The wet deposition scheme in TM5 describes the removal of gases and aerosols from the atmosphere by raining clouds, and distinguishes between convective and large-scale stratiform precipitation. Scavenging by precipitation formation in convective clouds is included in the convective mass transport operator as part of the mass fluxes entrained in the cumulus updrafts (Balkansi et al., 1993; Guelle et al., 1998). Aerosols and irreversibly soluble gases are assumed to be completely scavenged in vigorous convective updrafts, while the removal efficiencies of other gases are reduced depending on their solubility. Resolution dependencies are reduced by scaling down the convective scavenging rates for all tracers, depending on the grid-cell mean convective precipitation at the surface (see Vignati et al., 2010a).

For stratiform precipitation both in-cloud and below-cloud scavenging of gases and aerosols are considered as described by Roelofs and Lelieveld (1995) and Jeuken et al. (2001). Scavenging by precipitation formation inside stratiform clouds is assumed to be five times less effective for ice particles than for liquid droplets. In-cloud scavenging 
of aerosols is included only for the soluble accumulation and coarse modes, and for bulk aerosols like ammonium, nitrate, MSA, and lead-210. The in-cloud scavenging coefficients for the soluble accumulation and coarse modes are assumed to be equal to the values for irreversibly soluble gases, while for bulk aerosols they are reduced by $30 \%$ to account for the presence of interstitial aerosols (Vignati et al., 2010a). Below-cloud scavenging of aerosols is modelled using estimates of bulk washout coefficients for the various modes based on Dana and Hales (1976). Resolution dependencies in wet removal by stratiform precipitation are reduced by the introduction of a mixing timescale, which delays the subgridscale mixing between cloudy and cloud-free regions (see Vignati et al., 2010a).

\subsubsection{Boundary conditions}

A detailed description of stratospheric chemistry is not included in the model. To simulate stratospheric ozone chemistry a parameterized linear chemistry scheme can be used (Cariolle and Teyssèdre, 2007; McLinden et al., 2000; Van Noije et al., 2004, 2006). Alternatively, the $\mathrm{O}_{3}$ concentrations in the stratosphere can simply be relaxed towards observational values, as described in Huijnen et al. (2010). In the current relaxation scheme, total $\mathrm{O}_{3}$ column estimates from a multi-sensor reanalysis (van der A et al., 2010) are combined with a climatological data set of vertical profiles constructed from sonde and satellite observations (Fortuin and Kelder, 1998). A similar relaxation procedure is applied to the $\mathrm{CH}_{4}$ concentrations in the stratosphere, while $\mathrm{HNO}_{3}$ is constrained by prescribing the concentration ratio of $\mathrm{HNO}_{3}$ over $\mathrm{O}_{3}$ at $10 \mathrm{hPa}$. These stratospheric boundary conditions are primarily based on satellite data (see Huijnen et al., 2010). This is adequate for the present-day decadal simulations presented in this study, but additional data sets based on output from stratospheric chemistry models are needed for representing the longer-term trends and variability in simulations that start in the pre-satellite era or continue into the future.

Because of the relatively long lifetime of $\mathrm{CH}_{4}$, an additional constraint can be imposed on the $\mathrm{CH}_{4}$ concentrations at the surface. This is common practice in chemistry models in which the $\mathrm{CH}_{4}$ lifetime, which is mainly determined by the amount and distribution of the hydroxyl radical $(\mathrm{OH})$ in the troposphere, is not prescribed or tuned. It prevents drifts and/or biases in the global $\mathrm{CH}_{4}$ concentration, which would otherwise result from inconsistencies between the $\mathrm{CH}_{4}$ sources and sinks. This constraint can be imposed by relaxing the zonal mean surface concentrations of $\mathrm{CH}_{4}$ to values consistent with observations, while at the same time including the location dependent emissions of $\mathrm{CH}_{4}$. Alternatively, the $\mathrm{CH}_{4}$ concentrations at the surface can be prescribed using zonal and monthly mean fields based on observed values. In both cases, future concentration scenarios may be imposed by scaling the target concentration fields based on the projected evolution of the global mean concentration.

\subsubsection{Emissions}

Emissions from anthropogenic activities and biomass burning are taken from the data set provided for the Atmospheric Chemistry and Climate Model Intercomparison Project (ACCMIP), which was also used in CMIP5. The historical part of this data set covers the period 1850-2000 (Lamarque et al., 2010). The estimates for the year 2000 are based on a combination of regional and global inventories for the various sectors. The reconstruction for earlier decades is forced to agree with these estimates. For the 21st century emission projections from the representative concentration pathways (RCPs) are used (Van Vuuren et al., 2011). The RCP emissions start from the historical inventory in 2000. The RCP emissions are provided as monthly emissions for the years 2000, 2005, 2010, 2020, etc. A linear interpolation of the seasonal cycle is applied to obtain the emissions in the intermediate years.

Oceanic emissions of DMS and $\mathrm{NO}_{\mathrm{x}}$ production by lightning are calculated online as in Huijnen et al. (2010). Terrestrial DMS emissions from soils and vegetation are prescribed following Spiro et al. (1992). Sea salt emissions are calculated online as in Vignati et al. (2010b), based on the parameterization by Gong (2003). The emission rate is assumed to depend on the $10 \mathrm{~m}$ wind speed as a power law with exponent 3.41 (Monahan and Muircheartaigh, 1980). Emissions of mineral dust can either be calculated online based on the parameterization by Tegen et al. (2002) or be prescribed using the monthly data set for the year 2000 from the AeroCom project, described by Dentener et al. (2006).

Natural emissions of CO, NMVOCs, $\mathrm{NO}_{\mathrm{x}}, \mathrm{NH}_{3}$, and $\mathrm{SO}_{2}$ are prescribed using a monthly varying data set compiled for the Monitoring Atmospheric Composition and Climate (MACC) project. It includes (1) biogenic emissions of isoprene and number of other NMVOC species as well as CO from vegetation based on the Model of Emissions of Gases and Aerosols from Nature (MEGAN) version 2.1 (Guenther et al., 2012) for the year 2000; (2) biogenic emissions of $\mathrm{NO}_{\mathrm{x}}$ from soils based on Yienger and Levy (1995); (3) oceanic emissions of CO and NMVOCs from Olivier et al. (2003); (4) biogenic emissions of $\mathrm{NH}_{3}$ from soils under natural vegetation and oceanic emissions of $\mathrm{NH}_{3}$ from Bouwman et al. (1997); and (5) $\mathrm{SO}_{2}$ fluxes from continuously emitting volcanoes from Andres and Kasgnoc (1998). The emissions of radon-222 are prescribed as in Dentener et al. (1999). Following the recommendations of Rasch et al. (2000), the emission flux density is set at 1.0 atoms $\mathrm{cm}^{-2} \mathrm{~s}^{-1}$ for all land areas between $60^{\circ} \mathrm{S}$ and $60^{\circ} \mathrm{N}$ and to 0.5 atoms cm $\mathrm{cm}^{-2} \mathrm{~s}^{-1}$ for land areas between 60 and $70^{\circ} \mathrm{N}$, except in Greenland. Emissions in Greenland and other parts of the world are assumed to be zero.

As in Huijnen et al. (2010), a diurnal cycle is applied to the isoprene emissions from vegetation on top of the monthly 
estimates provided in the data set. To account for $\mathrm{SO}_{4}$ formation in sub-grid plumes, $2.5 \%$ of the sulfur in the $\mathrm{SO}_{2}$ emissions provided for the various sources is assumed to be emitted in the form of $\mathrm{SO}_{4}$ (Huijnen et al., 2010; Aan de Brugh et al., 2011). The size distributions assumed for the different particulate emission sources are listed in Aan de Brugh et al. (2011).

The implementation of emission heights has been revised compared to the description in Huijnen et al. (2010), based on estimates from several studies (Dentener et al., 2006; De Meij et al., 2006; Bieser et al., 2011; Simpson et al., 2012). The vertical distributions applied to the different emission sources are given in Table A1.

\section{Simulations}

In this study we present results from decadal simulations for the years 2000-2009, using 1999 as a spin-up year for the chemistry. The various simulations that were carried out are listed in Table 2.

In the atmosphere-ocean GCM simulation of EC-Earth, the historical part extends up to 2005 and is continued by a simulation based on scenario assumptions, in accordance with the CMIP5 experimental design for long-term climate simulations. As a future scenario, we adopt the RCP4.5 (Thomson et al., 2011), one of the stabilization scenarios of the representative concentration pathways. Please note that for the period considered the simulated climate will not be sensitive to the chosen scenario. The atmosphereocean GCM was initialized on 1 January 1999 from one of the CMIP5 20th century simulations performed by the ECEarth consortium. To be precise, the first ensemble member (SHC1) provided by the Swedish Meteorological and Hydrological Institute (SMHI) was used.

In TM5 the stratospheric $\mathrm{O}_{3}$ concentrations were relaxed as described in Sect. 2.2.8, using total column estimates for the years 2000-2009. Also, the surface $\mathrm{CH}_{4}$ concentrations were prescribed according to observations for those years. Emissions of $\mathrm{CH}_{4}$ were therefore not applied in these simulations.

Simulations were carried out both with and without yearly changes in the emissions from anthropogenic activities and biomass burning in TM5. In the reference EC-Earth simulation these emissions were fixed to their 2000 values. This reference simulation is compared with a corresponding TM5 simulation driven by meteorological data from the ECMWF reanalysis ERA-Interim (Dee et al., 2011). Both simulations are also evaluated against observational data. To estimate the impact of possible trends in the emissions, an additional ERA-Interim simulation is used with anthropogenic and biomass burning emissions varying between 2000 and 2009. In this simulation the anthropogenic and biomass burning emissions were prescribed according to the RCP4.5 scenario, consistent with the set-up of the atmosphere-ocean
GCM. Please note, however, that during the RCP development process a harmonization procedure has been applied to ensure that the emissions in the four different RCPs are still nearly identical in 2005. As a consequence the choice of the RCP will only have some albeit small effect on the chemistry during the second half of the simulation. Results from the ERA-Interim simulation with varying emissions have also been provided to the second phase of the AeroCom project. Aerosol concentrations and optical property fields from that simulation have been evaluated within that project (see http://aerocom.met.no). In all simulations, the emissions of mineral dust were prescribed using the AeroCom data set for the year 2000 (see Sect. 2.2.9).

The ERA-Interim input fields for TM5 have been created from the original ECMWF data during a pre-processing stage (see Krol et al., 2005). In this process the required meteorological and surface property fields are retrieved at a spectral resolution of $\mathrm{T} 255$ (corresponding to about $0.7^{\circ}$ ) and converted into TM5 input fields at a $1^{\circ} \times 1^{\circ}$ horizontal resolution, keeping the full 60-level vertical resolution of the original data. The ERA-Interim simulation was carried out at the same $3^{\circ} \times 2^{\circ}$ horizontal resolution as used in EC-Earth. However, because of the different vertical resolutions of the ERA-Interim data set and the CMIP5 EC-Earth simulations, the vertical grid is different. The ERA-Interim simulation was carried out using the same selection of 34 levels out of the original 60 levels of ERA-Interim as used in Huijnen et al. (2010). The treatment of the meteorological fields in the temporal dimension is also slightly different. In the ERAInterim simulation most meteorological fields are updated at a 3-hourly frequency (see Huijnen et al., 2010) and a linear interpolation is applied to the instantaneous fields.

Another difference relates to the representation of the tracer transport by cumulus convection. Historically, the required convective air mass fluxes and entrainment and detrainment rates were not archived in the meteorological data sets used to drive TM5. In the stand-alone version of TM5 these fields are therefore calculated diagnostically. This is done in a pre-processing step according to the parameterization of Tiedtke (1989). This scheme was introduced in ECMWF's operational forecast model in 1989. As the more recent schemes used in later IFS cycles, the original Tiedtke scheme already distinguished between deep, shallow and mid-level convection.

To estimate the impact of using diagnostically calculated convective mass fluxes and entrainment and detrainment rates, an additional decadal simulation was performed with the stand-alone version of TM5, but now driven by meteorological output from EC-Earth. The radon-222 concentrations from this offline simulation are compared with the results from the reference EC-Earth simulation, in which the data transfer from IFS to TM5 is done online through OASIS. For the offline EC-Earth simulation the driving meteorological fields for the years 1999-2005 were taken from the CMIP5 set of long-term historical simulations, which also 
Table 2. Overview of the decadal simulations used in this study.

\begin{tabular}{|c|c|c|c|c|c|c|}
\hline Simulation & Focus & $\begin{array}{l}\text { Emissions from } \\
\text { anthropogenic } \\
\text { activities and } \\
\text { biomass burning }\end{array}$ & $\begin{array}{l}\text { Number of vertical } \\
\text { levels in TM5/IFS }\end{array}$ & $\begin{array}{l}\text { Highest update } \\
\text { frequency of mete- } \\
\text { orological fields } \\
\text { in TM5 }\end{array}$ & $\begin{array}{l}\text { Temporal } \\
\text { interpolation of } \\
\text { instantaneous } \\
\text { meteorological } \\
\text { fields in TM5 }\end{array}$ & Convective fields \\
\hline EC-Earth & $\begin{array}{l}\text { Chemistry and } \\
\text { aerosols, radon-222 }\end{array}$ & Year 2000 & $31 / 62$ & 6 hourly & No & Received from IFS \\
\hline ERA-Interim & $\begin{array}{l}\text { Chemistry and } \\
\text { aerosols }\end{array}$ & Year 2000 & $34 / 60$ & 3 hourly & Linear & Diagnosed offline \\
\hline $\begin{array}{l}\text { ERA-Interim, } \\
\text { varying emissions }\end{array}$ & $\begin{array}{l}\text { Chemistry and } \\
\text { aerosols }\end{array}$ & 2000-2009 & $34 / 60$ & 3 hourly & Linear & Diagnosed offline \\
\hline Offline EC-Earth & Radon-222 & - & $31 / 62$ & 6 hourly & Linear & Diagnosed offline \\
\hline
\end{tabular}

provided the start fields for the online EC-Earth simulation. From this ensemble the first simulation provided by the Irish National Meteorological Service (MEI1) was selected. For the years 2006-2009 the corresponding member (ME41) of the ensemble of RCP4.5 simulations was used. As for ERAInterim, a pre-processing step was required to convert the IFS output into input fields for TM5. The online and offline ECEarth simulation were performed at the same horizontal and vertical resolutions. Also, the meteorological fields are updated with the same 6-hourly frequency. The remaining minor difference between the two simulations is that in the offline simulation a linear temporal interpolation is applied to the instantaneous meteorological fields, which is not possible in the online simulation (see Table 2).

The inclusion of atmospheric chemistry and aerosols substantially increases the computational burden of the simulations. In the configuration described above with 47 processors used for IFS and 32 for NEMO, the atmosphereocean version of EC-Earth simulates one year within less than $2 \mathrm{~h}$ on the ECMWF IBM POWER7 high-performance computer facility. Adding 45 processors for TM5 slows down the model by almost a factor 9 . We like to point out that the performance of the online-coupled IFS-NEMO-TM5 system is similar to that of the stand-alone version of TM5, when the same number of processors is used for TM5.

\section{Evaluation}

In this section an evaluation is presented of some important aspects of the atmospheric chemistry simulation with EC-Earth. With this objective monthly, seasonal, and/or annual mean 10 year climatologies from the reference EC-Earth simulation are compared with the corresponding climatologies from the ERA-Interim and offline EC-Earth simulations and/or with observational data sets. The variables of interest for which this has been done include temperature, humidity, the concentrations of various tracers, aerosol burdens and optical depth, and some important chemical budget terms. When comparing the climatologies from the different simulations and observational data sets, the interannual variability in the underlying data is used to calculate standard deviations and to determine the statistical significance of the differences. Regions where the differences are not statistically significant at the $5 \%$ level are indicated by the stippled areas in the figures.

When evaluating the model with ground-based observation from a particular station, we linearly interpolate the gridcell values from the model to the location of the station. The station height is used to estimate the corresponding pressure level based on a standard atmospheric profile (US Standard Atmosphere, 1976).

\subsection{Physical climate}

An evaluation of the physical climate of EC-Earth version 2.2 is presented by Hazeleger et al. (2012). In general the largescale structures of the atmosphere, ocean, and sea ice are well simulated and the main patterns of interannual climate variability are well represented. The climate of EC-Earth version 2.3 has qualitatively similar characteristics. In particular, the model has a cold bias in most of the troposphere throughout the year. A warm bias is found over the Southern Ocean, over the stratocumulus regions west of the continents in the subtropics, and over parts of the Northern Hemisphere (NH) extratropics, but only in the lower troposphere or near the surface. The middle and upper troposphere as well as the tropics and most of the Arctic are on average up to $3-4{ }^{\circ} \mathrm{C}$ too cold (see Fig. 1, top panels). Consequently, the specific humidity is also biased low in most of the troposphere, in particular in the tropics (Fig. 1, bottom panels). According to the Clausius-Clapeyron relation, the saturation vapour pressure in the lower troposphere decreases by about $7 \%$ per degree temperature decrease (Held and Soden, 2006). Assuming that the relative humidity is insensitive to the temperature bias, a cold bias of $1{ }^{\circ} \mathrm{C}$ would result in a local decrease in the specific humidity of about $7 \%$. Such a response of specific humidity to the temperature bias combined with a subsequent redistribution of the resulting local humidity bias due to horizontal and vertical transport can explain a large part of the observed bias in the humidity field in EC-Earth compared to ERA-Interim. 

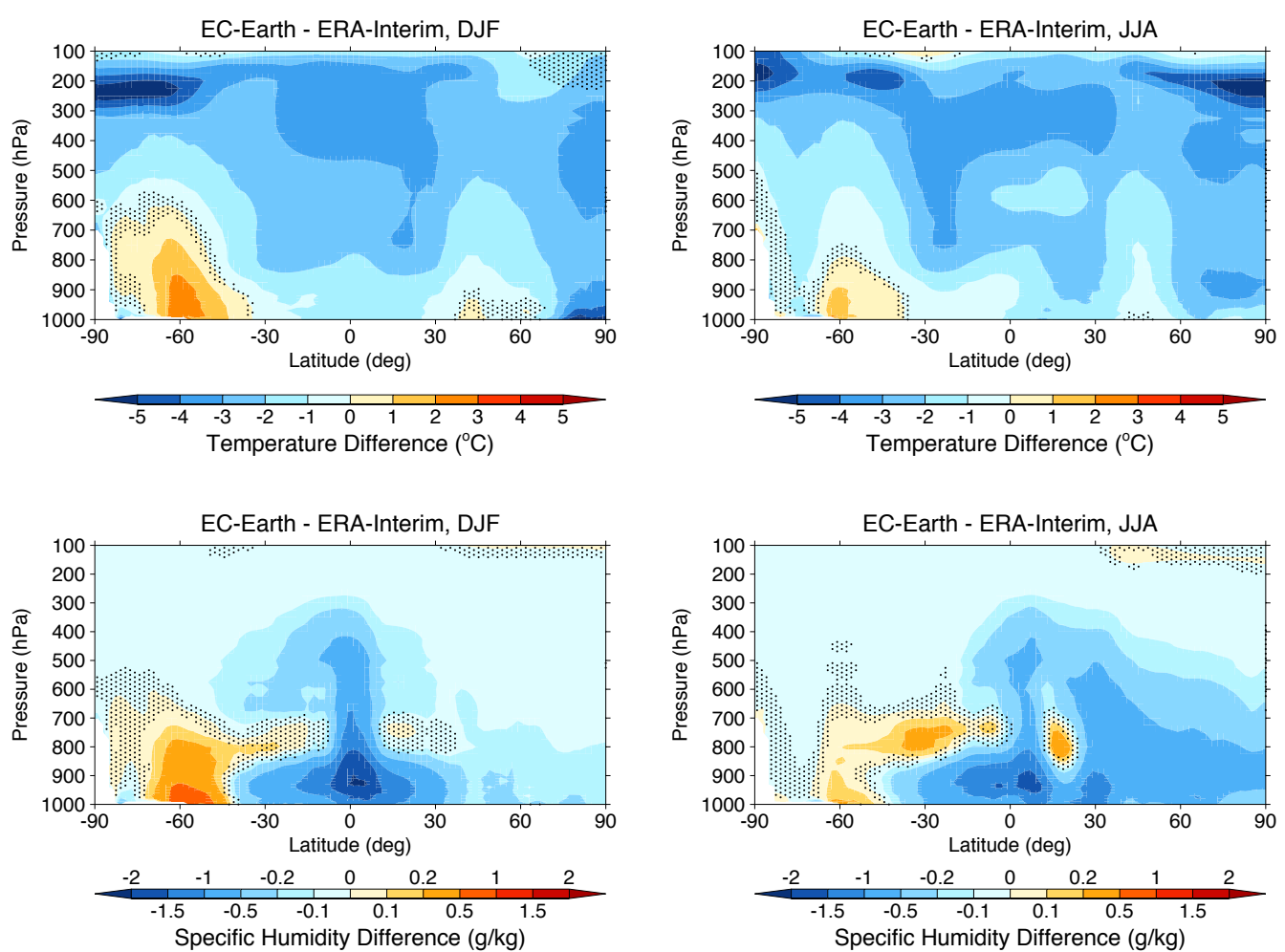

Figure 1. Zonal mean bias in temperature (top) and specific humidity (bottom) in EC-Earth compared to ERA-Interim for boreal winter (December-February, left) and boreal summer (June-August, right) for the period 2000-2009. Regions where the differences are not significant at the $5 \%$ level are indicated by the stippled areas.

Various aspects of the temperature and humidity biases in EC-Earth are also found in other climate models (see, e.g. Tian et al., 2013; Flato et al., 2013; Lamarque et al., 2013a). In particular, the CMIP5 model ensemble also produces a cold bias in most of the troposphere and a similar warm and wet bias over the Southern Ocean (Tian et al., 2013). The CMIP5 multi-model mean bias in annual mean temperature maximizes at about $2{ }^{\circ} \mathrm{C}$ in the extratropical upper troposphere. This is somewhat lower than the cold bias produced by EC-Earth in this region, which goes up to about $3^{\circ} \mathrm{C}$ in the $\mathrm{NH}$. Moreover, EC-Earth produces a stronger cold bias in the tropical troposphere than the CMIP5 model ensemble. As a consequence, the wet bias in the tropical lower troposphere is substantially stronger in EC-Earth. Finally, we note that the spatial distribution of surface temperature biases is qualitatively very similar for EC-Earth and the CMIP5 ensemble, at least in the annual mean (Flato et al., 2013).

\subsection{Radon-222}

Simulated radon-222 concentrations provide information about transport in the different model configurations, in particular transport from the continental boundary layer to the free troposphere and more remote regions. Differences between the reference, online EC-Earth simulation, and the ERA-Interim simulation are caused by a combination of factors: most significantly, (1) biases in the EC-Earth climate, (2) the different treatment of cumulus convection in EC-Earth, and (3) the 6-hourly update of the meteorological fields in EC-Earth (see Table 2). The effect of treating convection differently is evident in the comparison between radon concentrations from the online and offline EC-Earth simulations (see Sect. 3).

Figure 2 shows winter and summer zonal mean radon concentrations from the online EC-Earth simulation. Radon concentrations are highest over the continents, where the emissions take place. The highest zonal mean concentrations overall are simulated in the $\mathrm{NH}$ lower troposphere during boreal winter, when the boundary layer is most stable. For both hemispheres the concentrations in the upper troposphere are highest in summer, when the convective activity is strongest.

Compared to both offline simulations, the online EC-Earth simulation produces higher radon concentrations in large parts of the upper troposphere, extending from the tropics to mid-latitudes, and, during boreal winter, in the middle troposphere (above about $600 \mathrm{hPa}$ ) at northern mid-latitudes. The online simulation generally gives lower concentrations near the surface and in the lower troposphere, especially at northern mid-latitudes during winter. These features are due to the different treatment of convection and are in line with the fact that the updated convection scheme produces more intense 

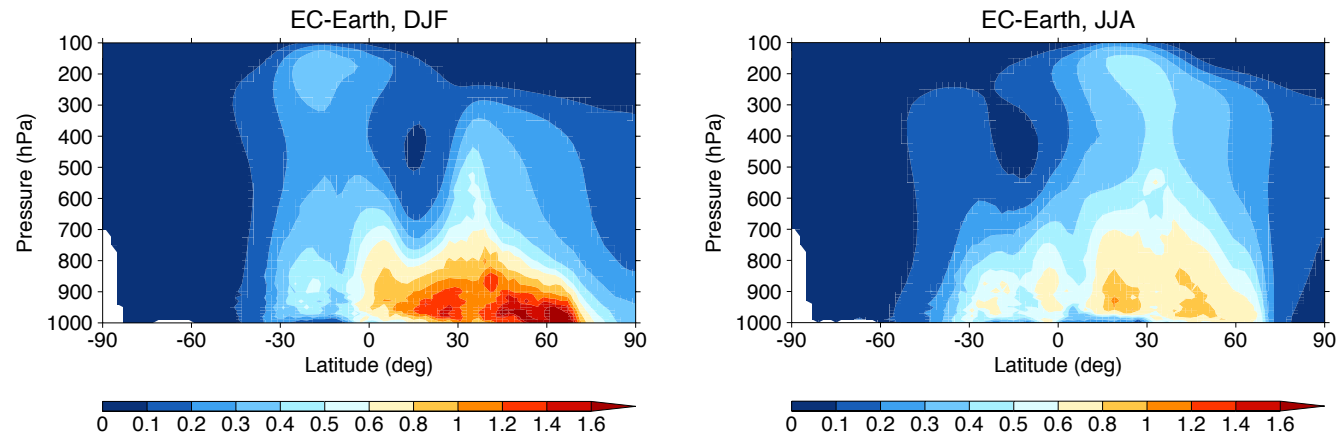
$\mathrm{Rn}-222\left(\mathrm{~Bq} / \mathrm{m}^{3}(\mathrm{STP})\right)$
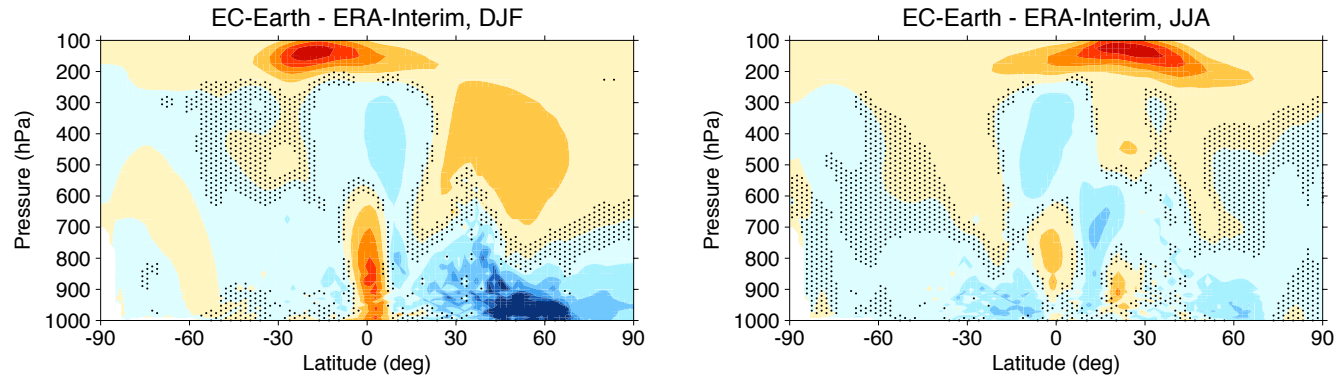

$\begin{array}{lllllll}-0.25-0.2-0.15-0.1-0.05 & 0 & 0.05 & 0.1 & 0.15 & 0.2 & 0.25\end{array}$ $\mathrm{Rn}-222$ Difference $\left(\mathrm{Bq} / \mathrm{m}^{3}(\mathrm{STP})\right)$
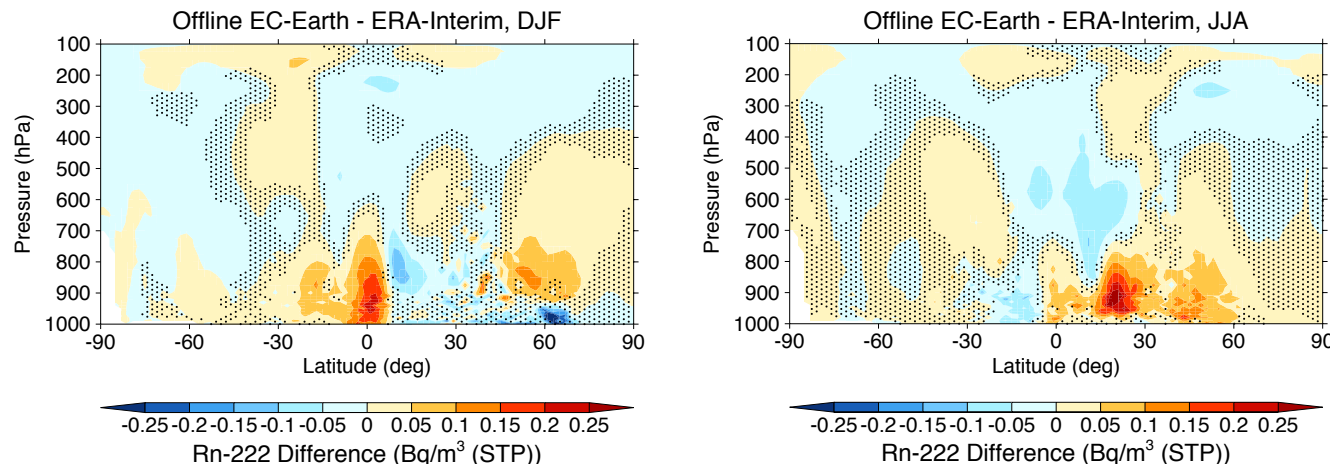

Figure 2. Zonal mean radon-222 concentrations in the online EC-Earth simulation (top) and the differences compared to the ERA-Interim (middle) and offline EC-Earth (bottom) simulations for boreal winter (left) and boreal summer (right).

continental convection and stronger upper-level convective detrainment (Bechtold et al., 2008).

Close to the equator both EC-Earth simulations produce higher zonal mean concentrations than the ERA-Interim simulation in the lower troposphere (up to about $700-600 \mathrm{hPa}$ ) and lower concentrations at higher altitudes up to about $200 \mathrm{hPa}$. The fact that this feature is common to both ECEarth simulations indicates that it is the result of biases in the EC-Earth climate and/or the 6-hourly update frequency of the meteorological fields.

The $6 \mathrm{~h}$ update frequency may not always be sufficient to capture the development of convective boundary layers over continental areas, which may lead to an overestimation of radon concentrations near the surface (Krol et al., 2005). The offline EC-Earth simulation indeed produces higher concentrations than the ERA-Interim simulation in parts of the lower troposphere and at higher latitudes, especially during summer in the NH. However, the online EC-Earth simulations give lower concentrations than the ERA-Interim simulation in these regions due to the opposing effect of stronger vertical transport resulting from the different treatment of convection. The update frequency will be reduced in future versions of the model.

We finish this section with a comparison between monthly radon concentrations from the simulations and ground-based observations. We present results for six stations, including two coastal sites (Cape Grim and Richmond, both in Australia), three island sites (Mauna Loa; Gosan on Jeju Island, 
South Korea; and Sado Island, Japan) and one continental site (Hohenpeissenberg, Germany). Data for Hohenpeissenberg have been taken from the World Data Centre for Greenhouse Gases (WDCGG); data for the other stations have been provided by the Australian Nuclear Science and Technology Organisation (ANSTO). All selected stations provide multi-annual data sets of hourly radon measurements (see Table A2). We calculated monthly climatologies based on the full period of available measurements, and compare these with the 10 year climatologies from the simulations.

The resulting observed and simulated seasonal cycles at the selected stations are shown in Fig. 3. Following earlier studies in which ground-based radon observations were used for evaluating global models (Dentener et al., 1999; Taguchi et al., 2002; Zahorowski et al., 2004), we applied a diurnal sampling window to the observations. The applied window is site specific (see Table A2), and is chosen to minimize contributions from small-scale effects not well resolved by the models. This is most relevant for sites like Richmond, where global models underestimate the trapping of radon in the nocturnal boundary layer, and mountainous and island sites like Mauna Loa, Gosan, and Sado, where models underestimate the influence of local emissions for various reasons (Zahorowski et al., 2005; Chambers et al., 2013). Application of a diurnal sampling window vastly improves comparisons with the simulated results for these stations (see Fig. 3). The resulting annual mean biases, root mean square errors, and correlation coefficients between the observed and simulated seasonal cycles are given in Table A2.

Many of the discrepancies between the modelled and observed radon seasonal cycles in Fig. 3 have also been found in other global modelling studies. Using the same radon emission fluxes as applied in our simulations, Dentener et al. (1999), Tagushi et al. (2002), and Zhang et al. (2011) reported underestimates for Mauna Loa all year round, and overestimates for Cape Grim during the austral summer. Moreover, the simulations reported by Zhang et al. (2008) also failed to reproduce the concentration increase measured at Hohenpeissenberg during boreal summer. Discrepancies may be partially related to inaccuracies in assumed emission fluxes. For example, emissions in continental Asia have been estimated to be higher than previously thought (Williams et al., 2009). Except during the summer monsoon season, higher Asian emissions estimates would substantially increase the simulated concentrations at Gosan and Sado Island (Chambers et al., 2009). Zhang et al. (2011) also obtained better agreements at Mauna Loa and Cape Grim using improved emissions estimates.

It is important to note that discrepancies between simulated and observed radon concentrations are generally larger than the differences amongst the three simulations. In order to use radon observations to evaluate the differences in the simulated transport, in particular the impacts of the different treatment of convection in the online EC-Earth simulation, it will be necessary to improve the set-up of the simulations using more accurate estimates of the spatially heterogeneous and seasonally varying radon emission fluxes (Zhang et al., 2011).

\subsection{Oxidizing capacity and methane lifetime}

The oxidizing capacity of the atmosphere is determined by the abundance and distribution of the hydroxyl radical $(\mathrm{OH})$ in the troposphere. $\mathrm{OH}$ is highly reactive and initiates most of the photochemical reaction chains that oxidize reactive gases in the atmosphere (Levy, 1971; Lelieveld et al., 2002, 2004). The production of $\mathrm{OH}$ in the troposphere is mainly governed by the photolysis of $\mathrm{O}_{3}$,

$\mathrm{O}_{3}+h v \rightarrow \mathrm{O}\left({ }^{1} \mathrm{D}\right)+\mathrm{O}_{2}$,

followed by the reaction of the excited oxygen atom, $\mathrm{O}\left({ }^{1} \mathrm{D}\right)$, with a water molecule:

$\mathrm{O}\left({ }^{1} \mathrm{D}\right)+\mathrm{H}_{2} \mathrm{O} \rightarrow 2 \mathrm{H}$.

The second step is limited by the availability of water molecules in the gas phase. On average only a few percent of the $\mathrm{O}\left({ }^{1} \mathrm{D}\right)$ atoms produced in the first reaction step will encounter a water molecule to react with and produce $\mathrm{OH}$ (Lelieveld et al., 2002). As a consequence, $\mathrm{OH}$ production rates are highest in the tropical lower and middle troposphere, due to the relatively high amounts of both sunlight and water vapour in those regions.

The zonal mean $\mathrm{OH}$ concentrations from the reference EC-Earth simulation for winter and summer are presented in the top panels of Fig. 4. Compared to the monthly climatology presented by Spivakovsky et al. (2000), the region of high $\mathrm{OH}$ concentrations extends more towards the surface. In other respects, the large-scale features of the spatial distributions are very similar in all seasons. The peak concentrations in the tropics and subtropics are substantially lower in EC-Earth, especially in boreal winter and the transition seasons. However, based on simulations of methyl chloroform, it has been concluded that the $\mathrm{OH}$ concentrations from Spivakovsky et al. (2000) are likely too high. A better correspondence with the observed decay of methyl chloroform concentrations was obtained by reducing the climatology of Spivakovsky et al. (2000) by $8 \%$ (see Huijnen et al., 2010). Compared to the optimized climatology thus obtained (shown in the middle panels of Fig. 4), the peak concentrations from the EC-Earth simulation are quantitatively similar in boreal summer, but at least $20 \%$ lower in the other seasons.

Compared to the ERA-Interim simulation, EC-Earth produces lower $\mathrm{OH}$ concentrations in large parts of the tropical and subtropical troposphere. As shown in the bottom panels of Fig. 4, the zonal mean concentrations are lower in a region extending from close to the surface to about $200 \mathrm{hPa}$. The lower $\mathrm{OH}$ concentrations in this region are mainly caused by lower temperatures, resulting in lower specific humidities. Because there is less water vapour available to react with 

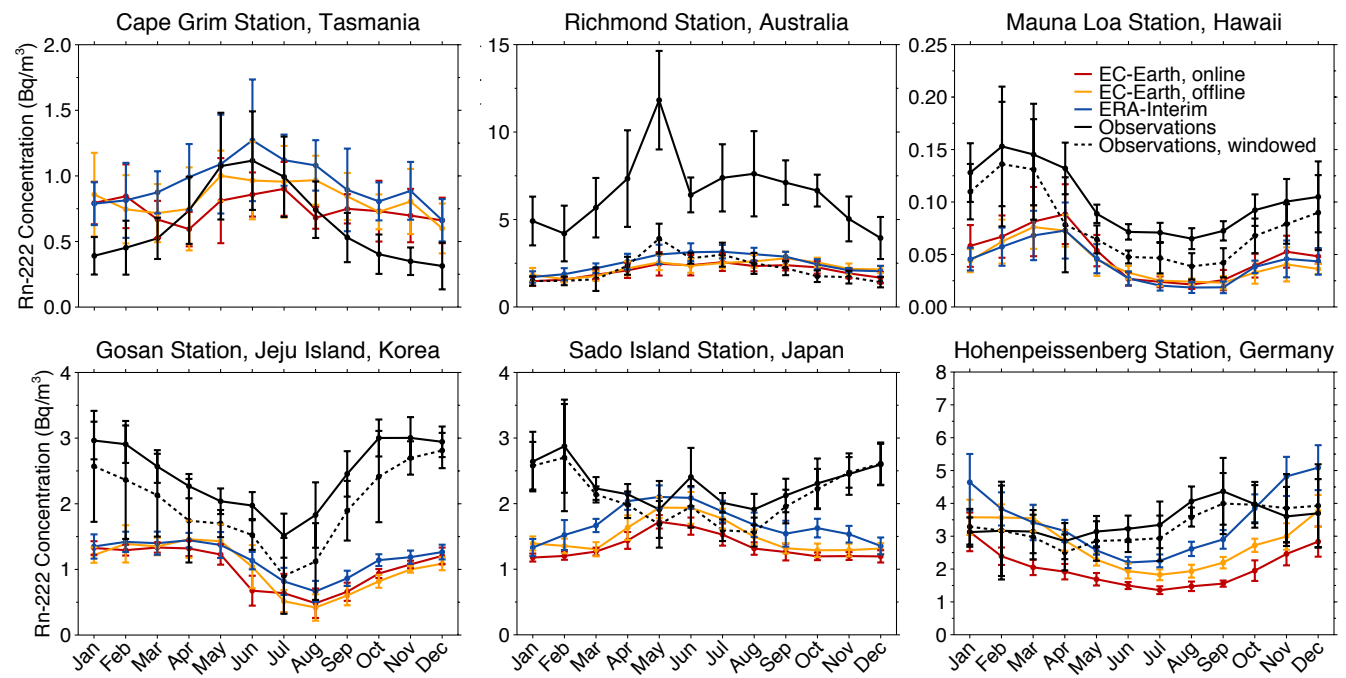

Figure 3. Comparison of monthly mean surface radon-222 concentrations from the online and offline EC-Earth simulations (solid red and orange lines, respectively) and the ERA-Interim simulation (solid blue lines) against surface measurements (black lines). The observational means shown by the dashed lines only include the measurements made within a certain station dependent diurnal window (see Table A2).

Table 3. Contributions to the chemical production of $\mathrm{OH}$ in the troposphere $\left(\mathrm{Tg} \mathrm{OH}_{\text {year }}{ }^{-1}\right)$ for the reference EC-Earth simulation and the corresponding ERA-Interim simulation. The contributions from $90-30^{\circ} \mathrm{S}, 30^{\circ} \mathrm{S}-30^{\circ} \mathrm{N}$, and $30-90^{\circ} \mathrm{N}$ are given by the numbers between parentheses. Results have been obtained from a monthly analysis with a fixed tropopause level, set to the uppermost model layer for which the monthly mean $\mathrm{O}_{3}$ mixing ratio is below 150 ppbv. Standard deviations are based on the simulated interannual variability.

\begin{tabular}{lcc}
\hline Reaction & EC-Earth & ERA-Interim \\
\hline $\mathrm{O}\left({ }^{1} \mathrm{D}\right)+\mathrm{H}_{2} \mathrm{O}$ & 1432 & 1554 \\
$\mathrm{NO}+\mathrm{HO}_{2}$ & $(112 / 1120 / 199)$ & $(102 / 1243 / 208)$ \\
& 994 & 1002 \\
$\mathrm{O}_{3}+\mathrm{HO}_{2}$ & $(81 / 649 / 264)$ & $(65 / 682 / 255)$ \\
& 393 & 393 \\
$\mathrm{H}_{2} \mathrm{O}_{2}+h v$ & $(42 / 249 / 102)$ & $(37 / 263 / 93)$ \\
& 197 & 230 \\
$\mathrm{Other}$ & $(18 / 149 / 29)$ & $(20 / 175 / 34)$ \\
& 168 & 176 \\
Total & $(12 / 139 / 17)$ & $(13 / 144 / 18)$ \\
& $3184 \pm 20$ & $3355 \pm 30$ \\
& $(266 / 2307 / 611)$ & $(238 / 2508 / 608)$ \\
\hline
\end{tabular}

$\mathrm{O}\left({ }^{1} \mathrm{D}\right)$, the production of $\mathrm{OH}$ via the reaction path described above is lower than in the ERA-Interim simulation (see Table 3).

At higher latitudes, the $\mathrm{OH}$ concentrations from EC-Earth are generally higher than in the ERA-Interim simulation. As will be shown in Sect. 4.5, EC-Earth produces higher $\mathrm{O}_{3}$ concentrations in most of the lower and middle troposphere, especially in the extratropics. This increases the $\mathrm{O}\left({ }^{1} \mathrm{D}\right)$ production rates, especially in the summer hemisphere. In the
Southern Hemisphere (SH) extratropical lower troposphere the difference in the $\mathrm{OH}$ concentrations between the ECEarth and ERA-Interim simulations is further enhanced by the higher levels of humidity in EC-Earth associated with the warm bias over the Southern Ocean.

In the tropical upper troposphere (above about $200 \mathrm{hPa}$ ), the $\mathrm{OH}$ concentrations in EC-Earth are also higher than in the ERA-Interim simulation. This is likely related to the fact that some of the tracers involved in the other reactions that produce $\mathrm{OH}$ (see Table 3 ) are more efficiently transported to higher altitudes by deep convection (see Sect. 4.2).

Differences in the amount and distribution of the $\mathrm{NO}_{\mathrm{x}}$ production by lightning also affect the distribution of $\mathrm{OH}$. The global production of $\mathrm{NO}_{\mathrm{x}}$ by lightning is significantly higher in EC-Earth than in the ERA-Interim simulation (see Table A3); the production in EC-Earth is 0.84 and $0.51 \mathrm{Tg} \mathrm{N}$ year $^{-1}$ higher in the $\mathrm{NH}$ and $\mathrm{SH}$ extratropics, respectively, while it is $0.74 \mathrm{Tg} \mathrm{N}_{\text {year }}{ }^{-1}$ lower in the tropics $\left(30^{\circ} \mathrm{S}-30^{\circ} \mathrm{N}\right)$.

The lower $\mathrm{OH}$ concentrations in the tropical and subtropical lower and middle troposphere lead to a slower removal of $\mathrm{CH}_{4}$ from the atmosphere. The average chemical lifetime of $\mathrm{CH}_{4}$ against reaction with tropospheric $\mathrm{OH}$ is 10.9 years in the EC-Earth simulation and 10.1 years in the ERA-Interim simulation. Both values are within the multimodel ranges of $9.7 \pm 1.7,10.2 \pm 1.7$, and $9.7 \pm 1.5$ years estimated by Shindell et al. (2006b), Fiore et al. (2009), and Naik et al. (2013), respectively, from simulations for present-day conditions (2000 or 2001). Assuming a lifetime of 120 and 160 years, respectively, for the chemical loss in the stratosphere and the soil sink (Ehhalt et al., 2001), the atmospheric lifetime of $\mathrm{CH}_{4}$ is 9.4 years in the EC-Earth simulations. This is $7 \%$ longer than the atmospheric lifetime of 

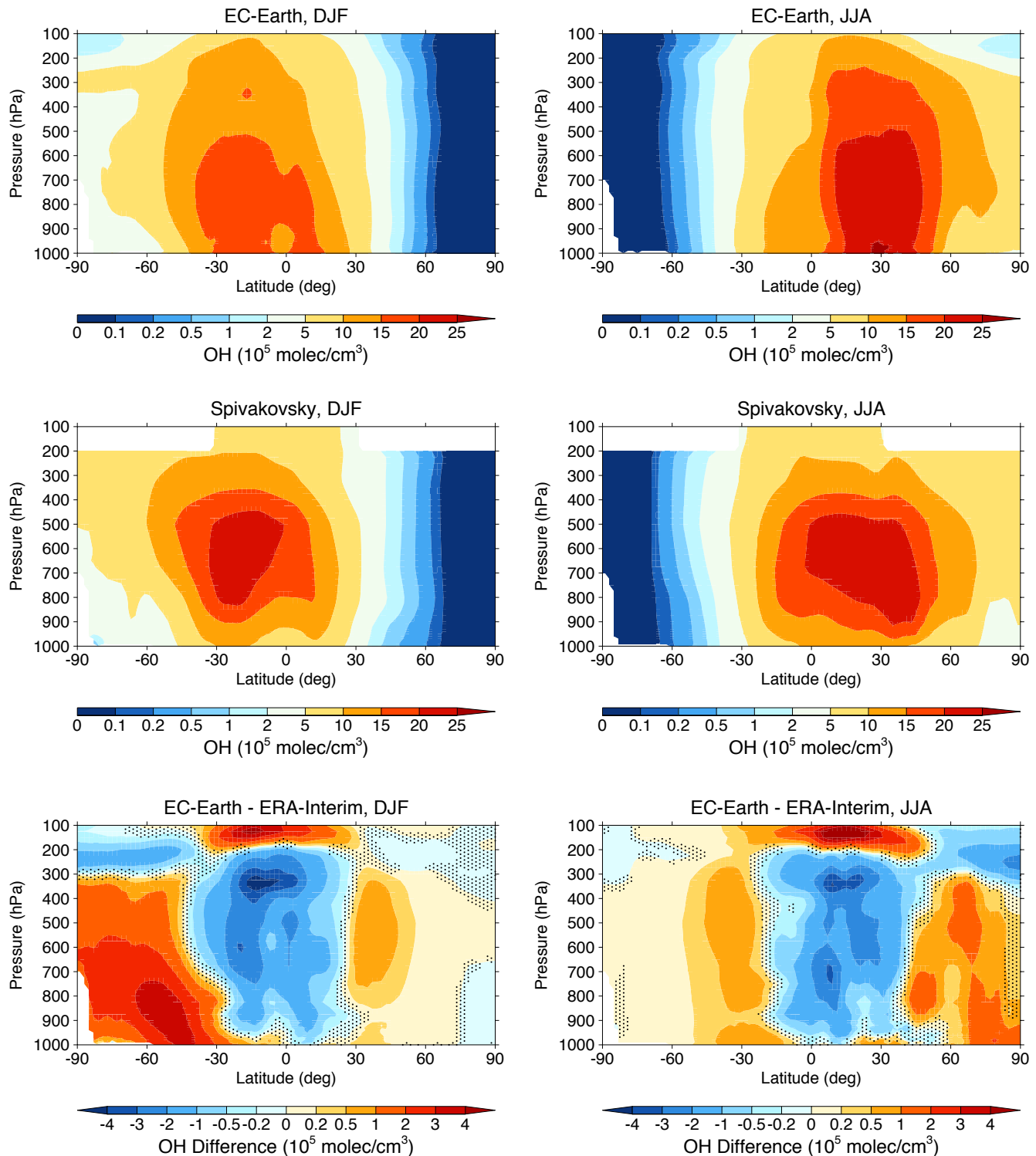

Figure 4. Zonal mean $\mathrm{OH}$ concentrations in the reference EC-Earth simulation (top), the climatology of Spivakovsky et al. (2000) reduced by $8 \%$ (middle), and the differences between the reference EC-Earth simulation and the corresponding ERA-Interim simulation (bottom) for boreal winter (left) and boreal summer (right).

8.8 years obtained in the ERA-Interim simulation. Prather et al. (2012) recently estimated from methyl chloroform observations that the present-day atmospheric lifetime of $\mathrm{CH}_{4}$ is in the range $9.1 \pm 0.9$ years. The values obtained in the ECEarth and ERA-Interim simulations are both well within this range.

\subsection{Carbon monoxide}

Carbon monoxide is emitted into the atmosphere by anthropogenic and natural sources and is chemically produced in the atmosphere by oxidation of $\mathrm{CH}_{4}$ and NMVOCs and by photolysis of certain NMVOCs. The oxidation of $\mathrm{CH}_{4}$ and many other hydrocarbons proceeds via the formation of formaldehyde $\left(\mathrm{CH}_{2} \mathrm{O}\right)$, which is subsequently converted to $\mathrm{CO}$ by photolysis or oxidation, mostly by reaction with $\mathrm{OH}$. $\mathrm{CO}$ is removed from the atmosphere by reaction with $\mathrm{OH}$ and by dry deposition at the surface. The various contributions to the atmospheric budget of CO in the EC-Earth and ERA-Interim simulations are given in Table 4.

The average lifetime of $\mathrm{CO}$ in the atmosphere (total burden divided by total loss) is 54.6 days in EC-Earth compared to 52.5 days with ERA-Interim. The slightly longer lifetime in EC-Earth is a result of a slower chemical destruction due to the lower $\mathrm{OH}$ concentrations in the tropical and subtropical troposphere. In contrast, $\mathrm{OH}$ levels in EC-Earth are higher in 
Table 4. Contributions to the budget of $\mathrm{CO}$ in the atmosphere ( $\mathrm{Tg} \mathrm{CO}_{\text {year }}{ }^{-1}$ ), together with the tropospheric and atmospheric burdens of $\mathrm{CO}$ ( Tg CO), and the atmospheric lifetime of $\mathrm{CO}$ (days) for the reference EC-Earth simulation and the corresponding ERA-Interim simulation. The contributions from $90-30^{\circ} \mathrm{S}, 30^{\circ} \mathrm{S}-30^{\circ} \mathrm{N}$, and $30-90^{\circ} \mathrm{N}$ are given by the numbers between parentheses. Results have been obtained from a monthly analysis with a fixed tropopause level, set to the uppermost model layer for which the monthly mean $\mathrm{O}_{3}$ mixing ratio is below $150 \mathrm{ppbv}$. Standard deviations are based on the simulated interannual variability.

\begin{tabular}{lcc}
\hline & EC-Earth & ERA-Interim \\
\hline Emissions & 1166 & 1166 \\
& $(23 / 762 / 381)$ & $(23 / 762 / 381)$ \\
Tropospheric chemical production & 1105 & 1170 \\
& $(81 / 838 / 186)$ & $(76 / 905 / 189)$ \\
Total gain* & 2284 & 2351 \\
& $(107 / 1606 / 572)$ & $(102 / 1674 / 574)$ \\
Dry deposition & $173 \pm 1.0$ & $180 \pm 1.5$ \\
& $(6 / 107 / 60)$ & $(6 / 105 / 69)$ \\
Tropospheric chemical destruction & 2065 & 2129 \\
& $(191 / 1447 / 427)$ & $(166 / 1541 / 422)$ \\
Total loss* & 2284 & 2352 \\
& $(208 / 1570 / 506)$ & $(184 / 1662 / 506)$ \\
Tropospheric burden & $316 \pm 2.0$ & $317 \pm 3.3$ \\
& $(53 / 179 / 84)$ & $(53 / 175 / 88)$ \\
Atmospheric burden & $341 \pm 2.5$ & $338 \pm 3.7$ \\
& $(61 / 185 / 95)$ & $(59 / 181 / 97)$ \\
Atmospheric lifetime & 54.6 & 52.5 \\
\hline * The total gain and loss also include small contributions from, respectively, chemical production \\
and destruction in the stratosphere.
\end{tabular}

the extratropics, causing a more efficient removal of $\mathrm{CO}$ at higher latitudes, especially in the SH.

Also the production of $\mathrm{CO}$ in the tropics and the subtropics is lower in EC-Earth. This is a direct consequence of a lower yield from the oxidation of $\mathrm{CH}_{4}$, caused by the lower $\mathrm{OH}$ concentrations in the tropics and subtropics. In order words, to obtain the same $\mathrm{CH}_{4}$ concentrations lower effective $\mathrm{CH}_{4}$ emissions are needed in EC-Earth, resulting in a lower production of $\mathrm{CO}$. The total chemical production of $\mathrm{CO}$ in both simulations is lower than the range of model estimates reported by Shindell et al. (2006b). This is likely due to an underestimation of the $\mathrm{CO}$ production from NMVOCs in the CBM4 chemistry scheme.

The global tropospheric burden of $\mathrm{CO}$ is similar in both simulations (Table 4). EC-Earth produces a lower burden in the tropics and a higher burden in the $\mathrm{NH}$ extratropics, but the differences are only a few percent. Compared to the ERA-Interim simulation, EC-Earth gives higher CO concentrations in the tropical upper troposphere and in the lower stratosphere (Fig. 5), mostly due to more efficient transport of $\mathrm{CO}$ by deep convection into the tropical upper troposphere. In the tropical lower and middle troposphere both higher and lower concentrations are observed depending on the location and the season. The concentrations in EC-Earth are lower in the NH extratropics, due to the faster chemical destruction. They are also somewhat lower in the SH extratropics in austral summer and, in the middle and upper troposphere, in austral winter.
The simulated surface mixing ratios of $\mathrm{CO}$ have been evaluated against monthly averages from the network of surface flask sampling of NOAA's Earth System Research Laboratory (ESRL) Global Monitoring Division (GMD). The decadal monthly mean mixing ratios from the simulations are compared with the flask measurements in Fig. 6. Since in the reference EC-Earth simulation and the corresponding ERA-Interim simulation the emissions from anthropogenic activities and biomass burning were fixed to their values for the year 2000, we have also included the results from the ERA-Interim simulation with emissions varying from year to year (see Table 2). The two ERA-Interim simulations give very similar decadal mean $\mathrm{CO}$ concentrations at the stations used in the evaluation (see Table A4 for a complete list). Thus, also the simulations with fixed emissions can be directly compared with the measurements.

At the measurement locations the concentration differences between the EC-Earth and ERA-Interim simulation are generally small in the $\mathrm{SH}$ and in the tropics and become larger in the NH extratropics (see Fig. 6 and Table A2). For the majority of stations the seasonal cycle is very well simulated, as expressed by a high correlation between the simulated and the measured monthly values. The simulated $\mathrm{CO}$ concentrations are generally in good quantitative agreement with the measurements in the SH. At the tropical stations in the $\mathrm{NH}$ both simulations underestimate the measurements by about equal amounts. At northern midlatitudes, both simulations underestimate the measurements, 

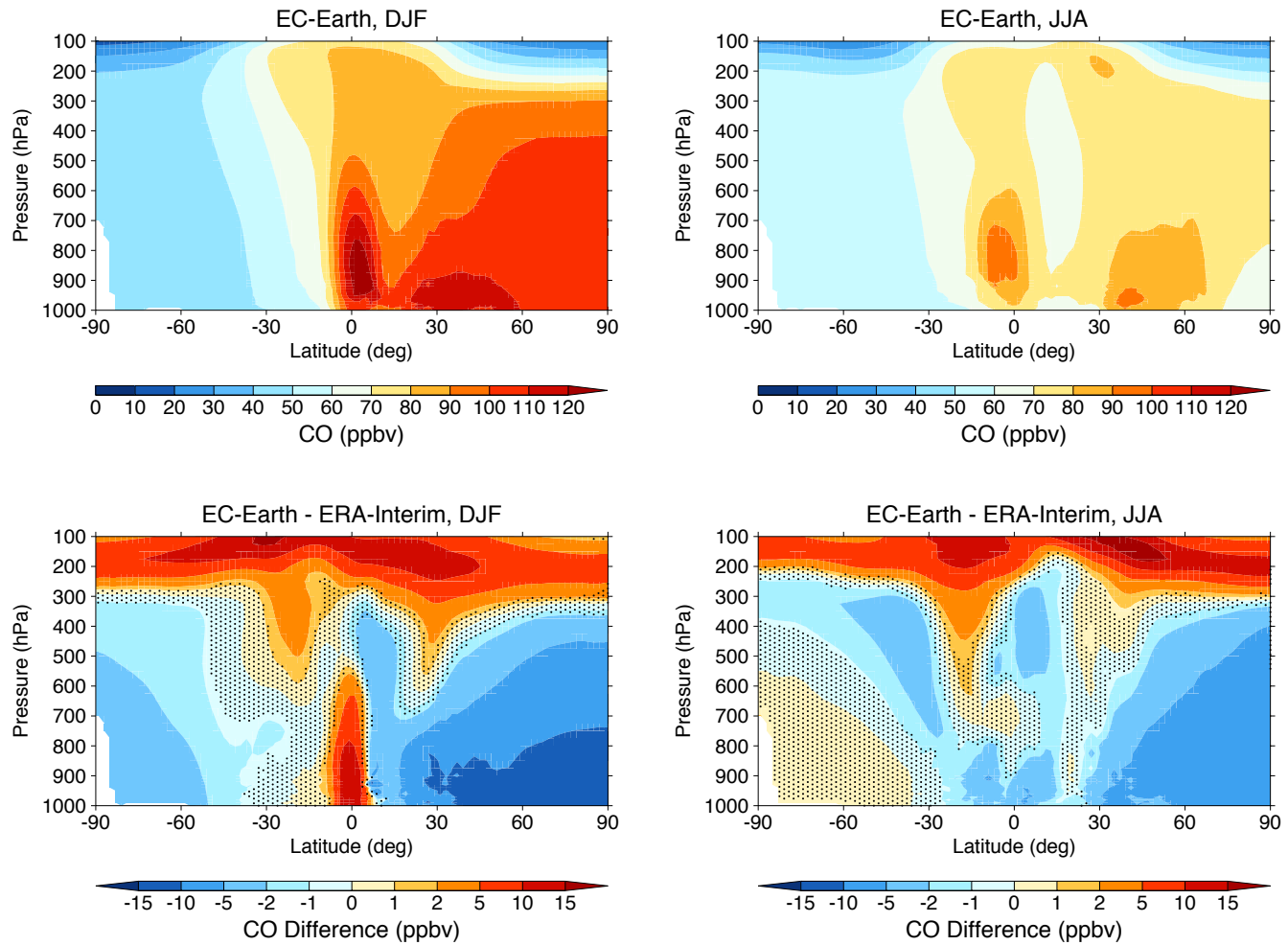

Figure 5. Zonal mean $\mathrm{CO}$ mixing ratios in the reference EC-Earth simulation (top) and the differences compared to the corresponding ERA-Interim simulation (bottom) for boreal winter (left) and boreal summer (right).

but the concentrations in EC-Earth are lower than with ERAInterim, especially outside of the summer season. In the annual mean the difference can be up to about 11 ppbv. The differences between the two simulations are generally smaller than the amounts by which the measurements are underestimated. We note that other modelling studies have shown similar $\mathrm{CO}$ biases in the $\mathrm{NH}$, using identical anthropogenic and biomass burning emissions (Lamarque et al., 2010; Naik et al., 2013).

\subsection{Ozone}

The sources of ozone in the troposphere are chemical production by the oxidation of $\mathrm{CO}, \mathrm{CH}_{4}$, and NMVOCs in the presence of $\mathrm{NO}_{\mathrm{x}}$, and net transport from the stratosphere. Ozone is removed from the troposphere by chemical destruction and by dry deposition at land surfaces. The chemical destruction of tropospheric $\mathrm{O}_{3}$ occurs mainly through the photolysis of $\mathrm{O}_{3}$ followed by the reaction of the produced excited oxygen atom with a water molecule (see Sect. 4.3) and through the reaction of $\mathrm{O}_{3}$ with the peroxy radical $\left(\mathrm{HO}_{2}\right)$ and with $\mathrm{OH}$. The main contributions to the tropospheric $\mathrm{O}_{3}$ budget in the EC-Earth and ERA-Interim simulations are given in Table 5 . These numbers can be directly compared with the ACCENT and ACCMIP multi-model results for the present day reported by Stevenson et al. (2006) and Young et al. (2013), who use a similar method for defining the tropopause. Note that Stevenson et al. (2006) give ranges based on the full ensemble of models participating in that study as well as on a subset of models that were selected based on criteria related to the simulation of $\mathrm{O}_{3}$ and the $\mathrm{CH}_{4}$ lifetime for the present day.

In EC-Earth the average lifetime of tropospheric $\mathrm{O}_{3}$ is 25.5 days, which is outside the ranges $22.3 \pm 2.0$ days and $22.2 \pm 2.2$ days estimated by Stevenson et al. (2006) for the full ensemble of ACCENT models and a subset of models, respectively, and corresponds to the highest value out of the six individual model results reported by Young et al. (2013). With ERA-Interim a lifetime of 23.9 days is obtained, which is within the ranges reported by these authors. The longer lifetime in EC-Earth is caused by a slower chemical destruction. The cold bias that exists in most of the troposphere slows down the destruction of $\mathrm{O}_{3}$ by photolysis because of the lower specific humidity. Lower concentrations of $\mathrm{OH}$ and $\mathrm{HO}_{2}$ in large parts of the tropical and subtropical troposphere (see Sect. 4.3) further slow down the destruction of $\mathrm{O}_{3}$.

EC-Earth produces a tropospheric $\mathrm{O}_{3}$ burden of $327 \mathrm{Tg}$, which is well within the ranges $344 \pm 39 \mathrm{Tg}$ and $336 \pm 27 \mathrm{Tg}$ reported by Stevenson et al. (2006) and the range $337 \pm 23 \mathrm{Tg}$ reported by Young et al. (2013). With ERAInterim a tropospheric burden of $309 \mathrm{Tg}$ is obtained, which is at the low side of the ranges estimated by Stevenson et al. (2006) and below the range estimated by Young et 

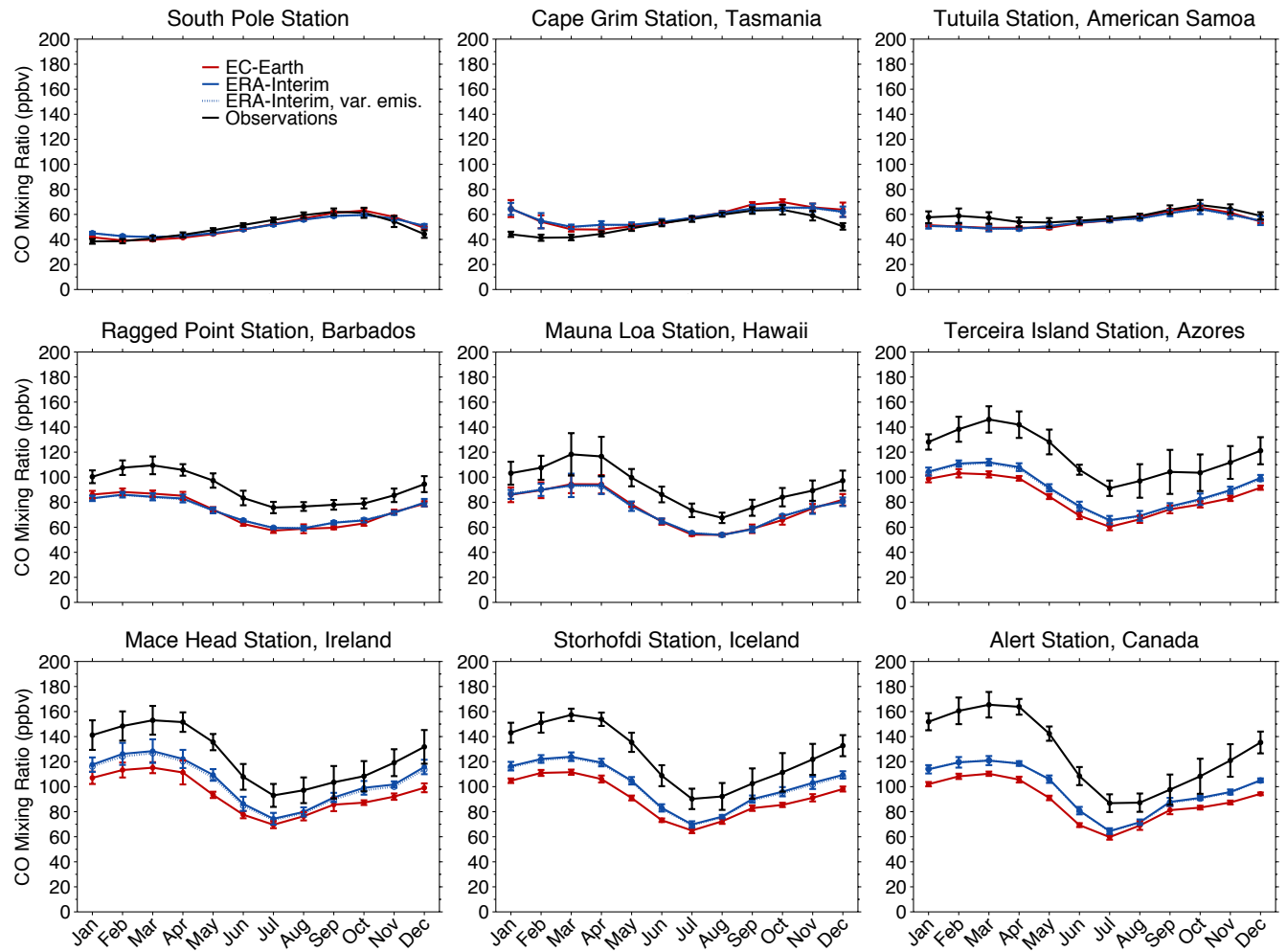

Figure 6. Comparison of monthly mean surface CO mixing ratios from the reference EC-Earth simulation (solid red lines) and the two ERAInterim simulations (solid and dotted blue lines) against flask measurements at a number of stations selected from the NOAA GMD network. The results from the ERA-Interim simulation with interannual variations in the emissions from anthropogenic activities and biomass burning (dotted blue lines) nearly coincide with those from the ERA-Interim simulation where these emissions are fixed to their values for the year 2000 (solid blue lines).

Table 5. Contributions to the budget of $\mathrm{O}_{3}$ in the troposphere $\left(\mathrm{Tg} \mathrm{O}_{3}\right.$ year ${ }^{-1}$ ), together with the tropospheric $\mathrm{O}_{3}$ burden $\left(\mathrm{Tg} \mathrm{O}_{3}\right)$, and the tropospheric $\mathrm{O}_{3}$ lifetime (days) for the reference EC-Earth simulation and the corresponding ERA-Interim simulation. The contributions from $90-30^{\circ} \mathrm{S}, 30^{\circ} \mathrm{S}-30^{\circ} \mathrm{N}$, and $30-90^{\circ} \mathrm{N}$ are given by the numbers between parentheses. Results have been obtained from a monthly analysis with a fixed tropopause level, set to the uppermost model layer for which the monthly mean $\mathrm{O}_{3}$ mixing ratio is below 150 ppbv. Standard deviations are based on the simulated interannual variability.

\begin{tabular}{lcc}
\hline & EC-Earth & ERA-Interim \\
\hline Chemical production & $4328 \pm 17$ & $4419 \pm 38$ \\
& $(339 / 2890 / 1099)$ & $(278 / 3070 / 1071)$ \\
Chemical destruction & $3698 \pm 24$ & $3873 \pm 39$ \\
& $(327 / 2656 / 714)$ & $(291 / 2896 / 687)$ \\
Dry deposition & $978 \pm 3.2$ & $851 \pm 4.1$ \\
Stratosphere-troposphere exchange & $(115 / 471 / 392)$ & $(84 / 425 / 341)$ \\
Burden & $349 \pm 10$ & $306 \pm 15$ \\
& $(66 / 161 / 100)$ & $309 \pm 1.7$ \\
Lifetime & 25.5 & $(59 / 162 / 88)$ \\
\hline
\end{tabular}

al. (2013). The higher burden in EC-Earth compared to the ERA-Interim simulation is mainly due to the slower chemical destruction of $\mathrm{O}_{3}$ in the troposphere and a higher net influx of $\mathrm{O}_{3}$ from the stratosphere. The influx from the stratosphere is $349 \mathrm{Tg}_{\mathrm{gear}}{ }^{-1}$ in EC-Earth compared to
$306 \mathrm{Tg}$ year ${ }^{-1}$ with ERA-Interim. Both values are below the ranges $552 \pm 168 \mathrm{Tg}_{\text {year }}{ }^{-1}$ and $556 \pm 154 \mathrm{Tg}_{\text {year }}{ }^{-1}$ estimated by Stevenson et al. (2006) and the model results reported by Young et al. (2013). Other model studies of stratosphere-troposphere exchange also found the net $\mathrm{O}_{3}$ 
flux to be higher than about $400 \mathrm{Tg}_{\mathrm{year}}{ }^{-1}$, in line with estimates based on observations (Olsen et al., 2004; Hsu et al., 2005). Thus, compared to the ERA-Interim simulation, the higher net stratosphere-troposphere exchange flux simulated in EC-Earth is likely an improvement.

Overall, the total chemical destruction of $\mathrm{O}_{3}$ in the troposphere is lower in EC-Earth than in the ERA-Interim simulation. The chemical production of $\mathrm{O}_{3}$ in the troposphere is also somewhat lower, but the net chemical production of $\mathrm{O}_{3}$ in the troposphere is still higher in EC-Earth. Combined with the higher net influx from the stratosphere this is consistent with a higher deposition of $\mathrm{O}_{3}$. The total deposition is $978 \mathrm{Tg}_{\text {year }}{ }^{-1}$ in EC-Earth, while $851 \mathrm{Tg}_{\text {year }}{ }^{-1}$ is obtained in the ERA-Interim simulation. Both results are within the ranges $1003 \pm 200 \mathrm{Tg} \mathrm{year}^{-1}$ and $953 \pm 154 \mathrm{Tg}$ year $^{-1}$ esti- $^{-}$ mated by Stevenson et al. (2006) and the model results reported by Young et al. (2013); however, the higher value obtained with EC-Earth is closer to the central estimates obtained by these authors.

EC-Earth produces higher zonal mean $\mathrm{O}_{3}$ concentrations than the ERA-Interim simulation in large parts of the troposphere, including most of the $\mathrm{NH}$ and the lower and middle parts of the SH (Fig. 7). Lower zonal mean concentrations are simulated in the tropical and subtropical upper troposphere and parts of the tropical and subtropical middle troposphere, and in parts of the lower stratosphere of the SH.

Differences in the contribution from $\mathrm{O}_{3}$ originating from the stratosphere explain part of the differences in the simulated $\mathrm{O}_{3}$ concentrations in the troposphere (compare the lower and middle panels of Fig. 7). This contribution was diagnosed using a stratospheric $\mathrm{O}_{3}$ tracer, $\mathrm{O}_{3}$ S. As in Lelieveld and Dentener (2000), $\mathrm{O}_{3 \mathrm{~S}}$ is subject to the same stratospheric boundary conditions and removal processes as regular $\mathrm{O}_{3}$, but is not produced below a certain pressure level, $\sim 140 \mathrm{hPa}$ in our model set-up. Since only small amounts of $\mathrm{O}_{3}$ are produced in the region between this level and the tropopause, effectively the chemical production is switched off in the troposphere. The $\mathrm{O}_{3 \mathrm{~S}}$ tracer therefore provides a robust method for estimating the contribution of $\mathrm{O}_{3}$ produced in the stratosphere to the tropospheric budget. The total chemical destruction and deposition of $\mathrm{O}_{3 \mathrm{~S}}$ in the troposphere is $351 \mathrm{Tg}_{\text {gear }}{ }^{-1}$ in EC-Earth and $305 \mathrm{Tg}_{\text {year }}{ }^{-1}$, very close to the estimates of the net stratosphere-troposphere exchange flux quoted above, which were obtained by closing the tropospheric budget of $\mathrm{O}_{3}$.

EC-Earth gives higher $\mathrm{O}_{3}$ concentrations than the ERAInterim simulation in the lowermost stratosphere at high northern latitudes (Fig. 7); this, combined with the slower chemical destruction in the troposphere, leads to higher $\mathrm{O}_{3 \mathrm{~S}}$ concentrations in most of the $\mathrm{NH}$. In the $\mathrm{SH}$, the lower zonal mean $\mathrm{O}_{3}$ concentrations simulated with EC-Earth in the subtropical upper and middle troposphere are partly due to a lower contribution from $\mathrm{O}_{3 \mathrm{~S}}$, especially in austral winter. At higher latitudes, on the other hand, the contribution from $\mathrm{O}_{3 \mathrm{~S}}$ in the troposphere is higher than in the ERA-Interim simulation. Concentration differences in the lower stratosphere between the EC-Earth and ERA-Interim simulations are the combined effect of differences in the large-scale stratospheric circulation, stratosphere-troposphere exchange and vertical resolution.

The slower chemical destruction due to the cold bias in EC-Earth increases the lifetime of $\mathrm{O}_{3}$ in the troposphere, and tends to increase the concentration of both $\mathrm{O}_{3 \mathrm{~S}}$ and $\mathrm{O}_{3}$. The resulting concentration increase is larger for $\mathrm{O}_{3}$ than for $\mathrm{O}_{3 \mathrm{~S}}$, but the increase in the $\mathrm{O}_{3}$ concentration is partly compensated by a reduced chemical production in the troposphere.

Differences in vertical exchange are also important to explain the differences in the $\mathrm{O}_{3}$ concentrations between the two simulations. The different treatment of convection in ECEarth leads to more efficient convection to the upper parts of the tropical troposphere (see Sect. 4.2). This tends to decrease the $\mathrm{O}_{3}$ concentrations in the tropical and subtropical upper troposphere. In the extratropics enhanced vertical mixing in EC-Earth tends to increase the $\mathrm{O}_{3}$ concentrations in the lower parts of the troposphere by bringing down more $\mathrm{O}_{3}$ from higher altitudes. Enhanced mixing similarly tends to increase the $\mathrm{O}_{3 \mathrm{~S}}$ concentrations in the lower extratropical troposphere. The latter effects are unique features of the online EC-Earth simulation, which are not reproduced in the offline EC-Earth simulation (not shown).

The simulated $\mathrm{O}_{3}$ concentrations have been evaluated against a vertically resolved, zonal, and monthly mean data set based on the $\mathrm{O}_{3}$ profile measurements from the Binary DataBase of Profiles (BDBP) of Hassler et al. (2008), which includes both satellite observations and ozonesondes. The data set used in the evaluation was constructed for the years 1979-2007 by Bodeker Scientific (www.bodekerscientific. com) in a similar way as described in Hassler et al. (2009).

In addition, the monthly mean $\mathrm{O}_{3}$ data set from Cionni et al. (2011) was included in the evaluation. This data set provided the $\mathrm{O}_{3}$ distribution for the CMIP5 climate models that did not calculate $\mathrm{O}_{3}$ interactively. The historical part of this data set extends to 2009. In the stratosphere it consists of zonal mean fields derived from a multiple linear regression analysis of satellite observations and polar ozonesonde data. In the troposphere it is based on simulations with the chemistry-climate models CAM3.5 (Lamarque et al., 2010) and GISS-PUCCINI (Shindell et al., 2006c) with prescribed sea surface temperatures. The anthropogenic and biomass burning emissions used in these simulations are the same as in the simulations presented here, and are also kept constant from 2000 to 2009.

In Figs. 8 and 9 the monthly mean $\mathrm{O}_{3}$ mixing ratios from the EC-Earth and ERA-Interim simulations are compared with the observational and CMIP5 data sets in latitude bands of $30^{\circ}$ at 750,500 , and $250 \mathrm{hPa}$. In these figures, the 20002009 means from the simulations are compared with the 2000-2007 means from the observational data set and the 2000-2009 means from the CMIP5 data set. 

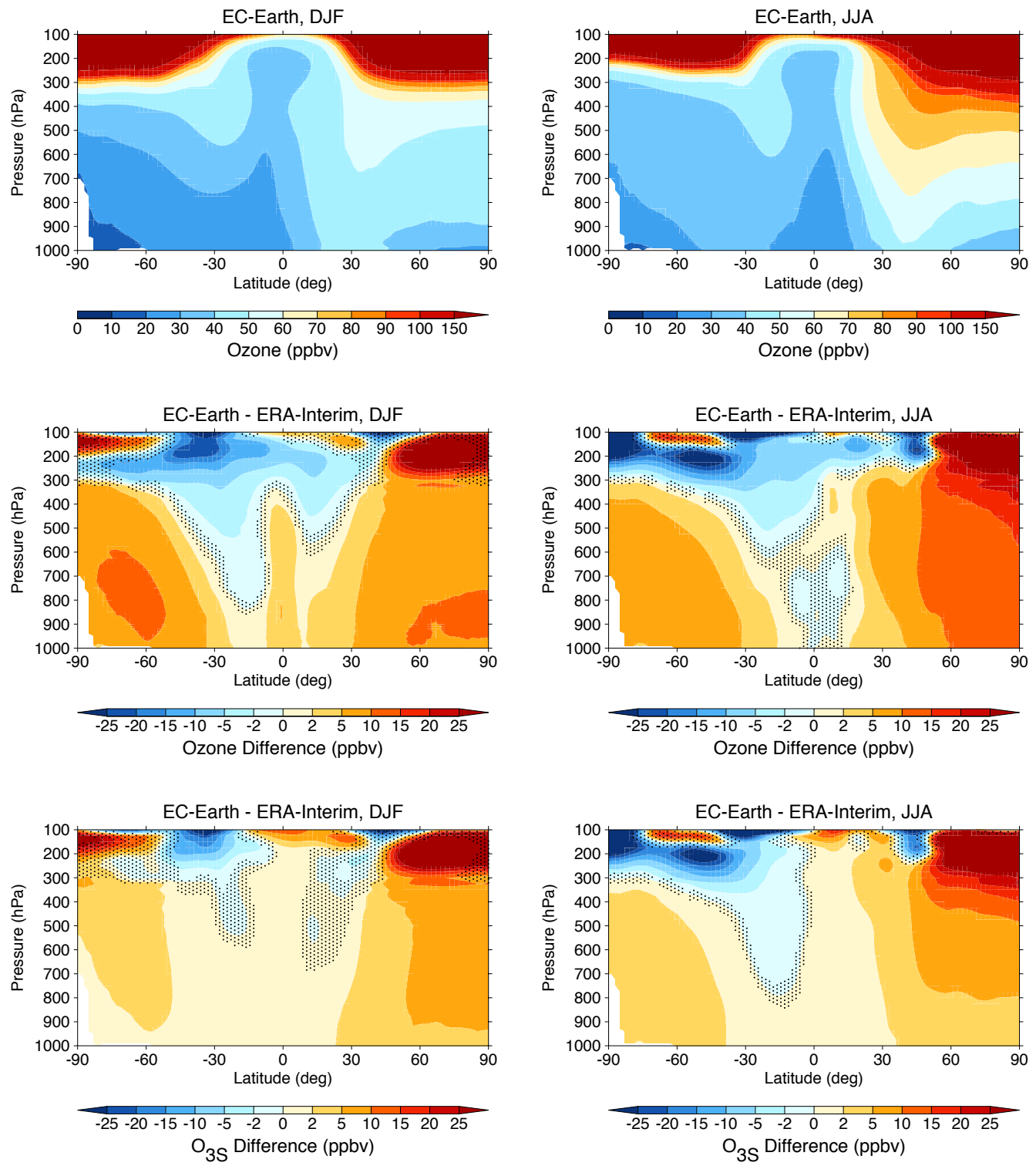

Figure 7. Zonal mean $\mathrm{O}_{3}$ mixing ratios in the reference EC-Earth simulation (top), the differences compared to the corresponding ERAInterim simulation (middle), and the contribution from the stratospheric $\mathrm{O}_{3}$ tracer $\left(\mathrm{O}_{3 \mathrm{~S}}\right)$ to these differences (bottom) for boreal winter (left) and boreal summer (right).

We first look at the extratropical upper troposphere-lower stratosphere $(250 \mathrm{hPa})$. Here EC-Earth gives higher $\mathrm{O}_{3}$ concentrations in the $\mathrm{NH}$ and lower concentrations in the $\mathrm{SH}$ than the ERA-Interim simulation. At high northern latitudes $\left(60-90^{\circ} \mathrm{N},\right)$, the higher concentrations obtained with ECEarth are in better agreement with the observational data set. However, EC-Earth underestimates the observational data in boreal spring and summer, which indicates that the downward transport in the lower stratosphere may still be too slow. Between 30 and $60^{\circ} \mathrm{N}$ the higher values obtained with EC-Earth lead to a somewhat stronger overestimation of the observational data. On the other hand, the CMIP5 data set shows even higher concentrations in this region during boreal winter and spring. At high southern latitudes $\left(60-90^{\circ} \mathrm{S}\right)$ both simulations underestimate the observational data, but the agreement is worse for EC-Earth. EC-Earth also underestimates the observational data between 30 and $60^{\circ} \mathrm{S}$, where the ERA-Interim simulation overestimates the observational data, especially in austral spring and summer. In this region the CMIP5 data set gives similar values as obtained with ECEarth.

In the extratropical middle and lower troposphere (500 and $750 \mathrm{hPa}$, respectively), EC-Earth gives significantly higher concentrations than the ERA-Interim simulation. In the $\mathrm{NH}$, EC-Earth agrees well with both the observational data and the CMIP5 data set in boreal winter. In boreal summer, the 

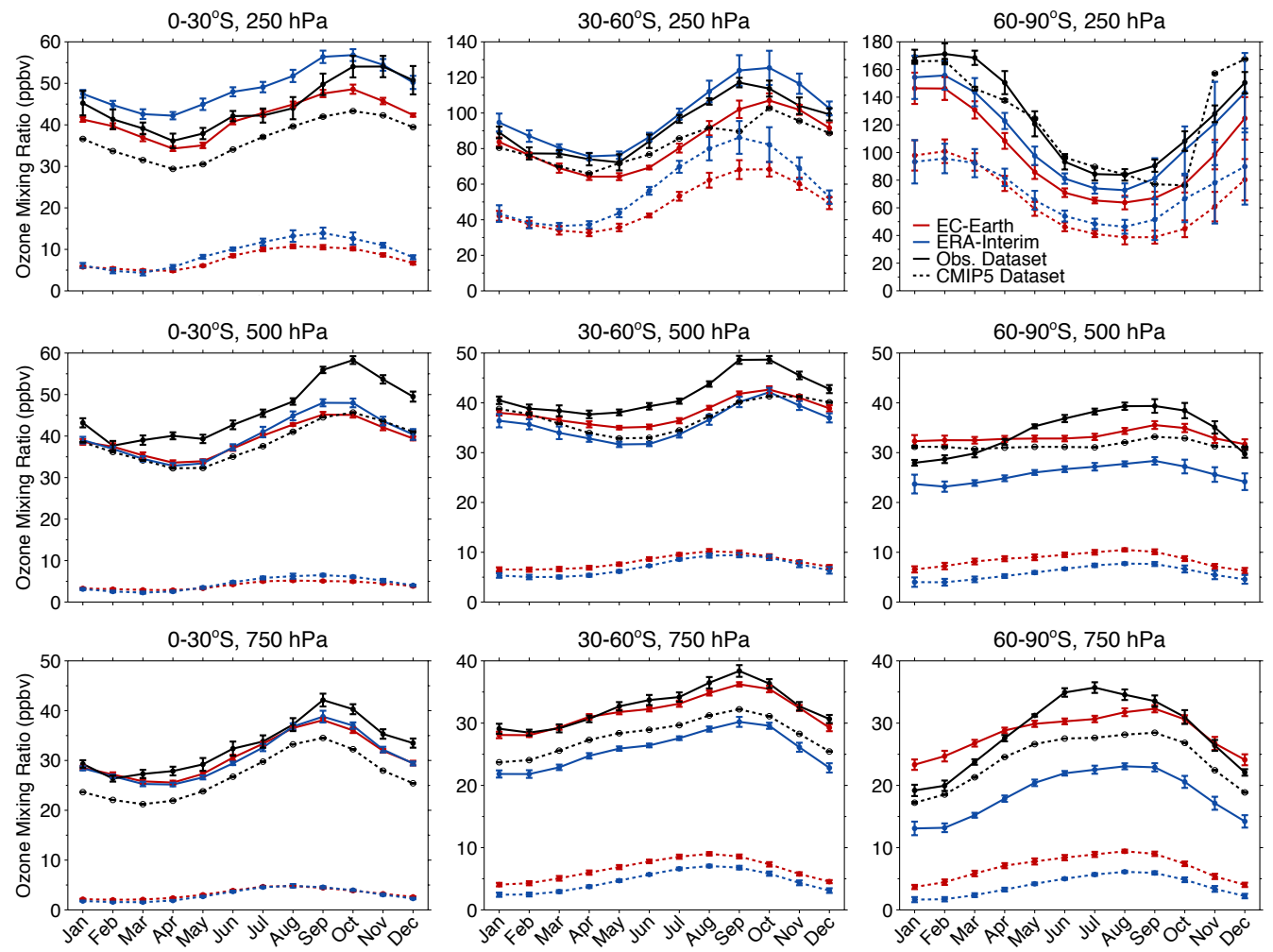

Figure 8. Monthly mean $\mathrm{O}_{3}$ mixing ratios at 750,500 , and $250 \mathrm{hPa}$ averaged over different latitude bands in the $\mathrm{SH}$. The results from the reference EC-Earth simulation (solid red lines) and the corresponding ERA-Interim simulation (solid blue lines) are compared against the observational data set (solid black lines) constructed from the Binary Database of Profiles (BDBP). The CMIP5 data set from Cionni et al. (2011) is indicated by the dashed black lines. The contributions from $\mathrm{O}_{3 \mathrm{~S}}$ for the EC-Earth and ERA-Interim simulations are shown by the dashed red and blue lines, respectively.

concentrations from EC-Earth are significantly higher than in the observational data set. In this season, the concentrations from the ERA-Interim simulation are either very close to $\left(30-60^{\circ} \mathrm{N}\right)$ or slightly lower than the observational estimates $\left(60-90^{\circ} \mathrm{N}\right)$. In the $\mathrm{SH}$, EC-Earth shows a much smaller bias relative to the observational data set. At high southern latitudes $\left(60-90^{\circ} \mathrm{S}\right)$, the concentrations from ECEarth are lower than the observational estimates during austral winter and higher during austral summer. EC-Earth is in excellent agreement with the observational data in the lower troposphere between 30 and $60^{\circ} \mathrm{S}$.

In the tropical upper troposphere $\left(30^{\circ} \mathrm{S}-30^{\circ} \mathrm{N}, 250 \mathrm{hPa}\right)$, EC-Earth produces lower values than the ERA-Interim simulation and is in fairly good agreement with the observational data set. The CMIP5 data set gives significantly lower values in this region.

In the tropical middle and lower troposphere, the differences between the EC-Earth and ERA-Interim simulation are relatively small. In the $\mathrm{NH}$ tropics $\left(0-30^{\circ} \mathrm{N}\right)$, EC-Earth gives somewhat higher concentrations. In the middle troposphere $(500 \mathrm{hPa})$, EC-Earth reproduces the observational data very well during boreal summer and fall, but gives lower values during winter and spring. In any case, EC-Earth is closer to the observational data than both the ERA-Interim simulation and the CMIP5 data set. In the lower troposphere $(750 \mathrm{hPa})$, EC-Earth agrees well with the observational data set in boreal spring and gives slightly higher values in the other seasons. Both simulations are in fairly good agreement with the observational data set. The CMIP5 data set gives significantly lower concentrations in this region. In the $\mathrm{SH}$ tropics $\left(0-30^{\circ} \mathrm{S}\right)$, both simulations underestimate the observation data, especially in the middle troposphere $(500 \mathrm{hPa})$. Here EC-Earth gives somewhat lower values than the ERAInterim simulation during austral winter and spring. The CMIP5 data set underestimates the observational data more strongly in the lower troposphere $(750 \mathrm{hPa})$, and also gives somewhat lower values than EC-Earth in the middle troposphere $(500 \mathrm{hPa})$ during austral winter and fall.

The results presented in Figs. 8 and 9 can be compared with the evaluation presented by Young et al. (2013), in which present-day tropospheric $\mathrm{O}_{3}$ concentrations from the ACCENT and ACCMIP model ensembles are compared with monthly climatological data sets based on ozonesonde measurements as well as satellite retrievals from the Tropospheric Emission Spectrometer (TES). In general, our simulations are within the range of concentrations simulated by 

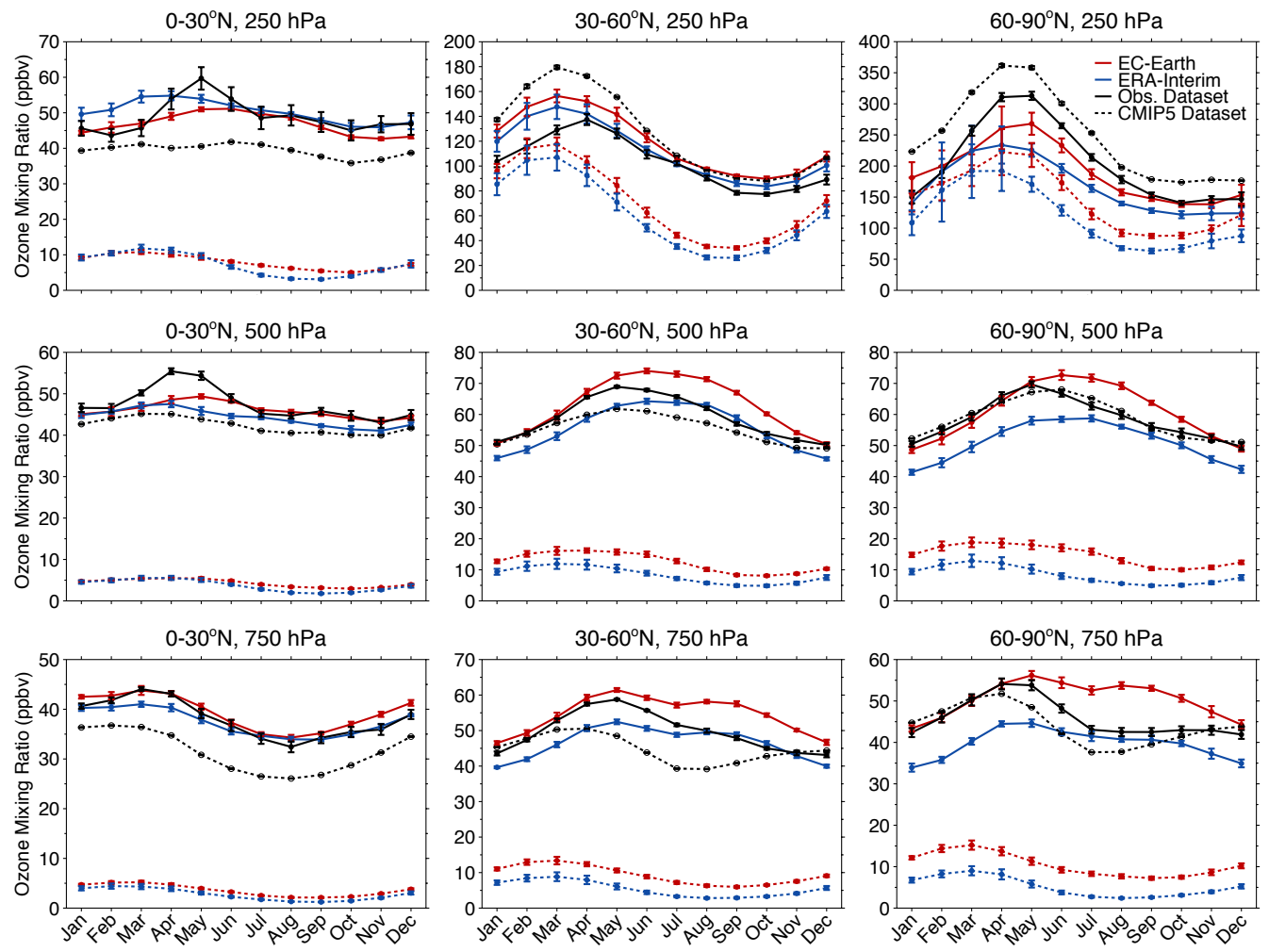

Figure 9. Same as Fig. 8, but for the NH.

the ACCMIP models. In particular, most ACCMIP models also underestimate the $\mathrm{O}_{3}$ concentrations in the middle and lower troposphere between 0 and $30^{\circ} \mathrm{S}$. Likewise they also underestimate the observed seasonal cycle in the upper and middle troposphere between 0 and $30^{\circ} \mathrm{N}$.

The surface $\mathrm{O}_{3}$ concentrations simulated with EC-Earth and the differences compared to the ERA-Interim simulation are presented in Fig. 10. EC-Earth gives higher surface concentrations in most of the world, with the exception of some regions located in the tropics and subtropics. In the mid- to high latitudes of the $\mathrm{NH}$, differences up to about $10 \mathrm{ppbv}$ are simulated during the winter season, while even larger differences are found during summer.

The simulated surface $\mathrm{O}_{3}$ concentrations have been evaluated against in situ surface measurements. The stations used for the evaluation of surface $\mathrm{O}_{3}$ are listed in Table A5. They include stations from the NOAA GMD network and a selection of stations included in the World Data Centre for Greenhouse Gases (WDCGG). Data for Mace Head were taken from the European Monitoring and Evaluation Programme (EMEP). Monthly averages were calculated from the hourly mixing ratio measurements and then averaged over the available years in the simulation period. Figure 11 shows the resulting monthly mixing values for a subset of stations spanning a broad range of latitudes, together with the decadal mean simulation results obtained at the corresponding locations. Simulation results are included for the reference EC-Earth simulation and the corresponding ERAInterim simulation, as well as for the ERA-Interim simulation with yearly changes in the emissions from anthropogenic activities and biomass burning (see Table 2). As for CO, the effect of these emission variations on the simulated decadal mean $\mathrm{O}_{3}$ concentrations at the stations used in the evaluation is very small, and sometimes barely visible. The simulations with fixed emissions can therefore again be directly compared with the measurements (see Fig. 11 and Table A5).

EC-Earth produces higher monthly mean surface concentrations than the ERA-Interim simulation at all stations, except at Mauna Loa (Hawaii), Tutuila (American Samoa) and Pyramid on Mount Everest (Nepal).

At the Antarctic stations, both simulations underestimate the measurements. Here EC-Earth is closer to the observations than the ERA-Interim simulation, but this is achieved at the expense of the correlation between the measured and simulated monthly concentrations. At Cape Grim (Tasmania), the seasonal cycle in both simulations is weaker than in the observations. EC-Earth is in excellent agreement with the observations during the winter months, but overestimates the observations during summer. The ERA-Interim simulation, on the other hand, is in good agreement during summer, but underestimates the observations during winter.

The ERA-Interim simulation also underestimates the measurements at high northern latitudes, especially during winter. Here EC-Earth is on average closer to the observations. 

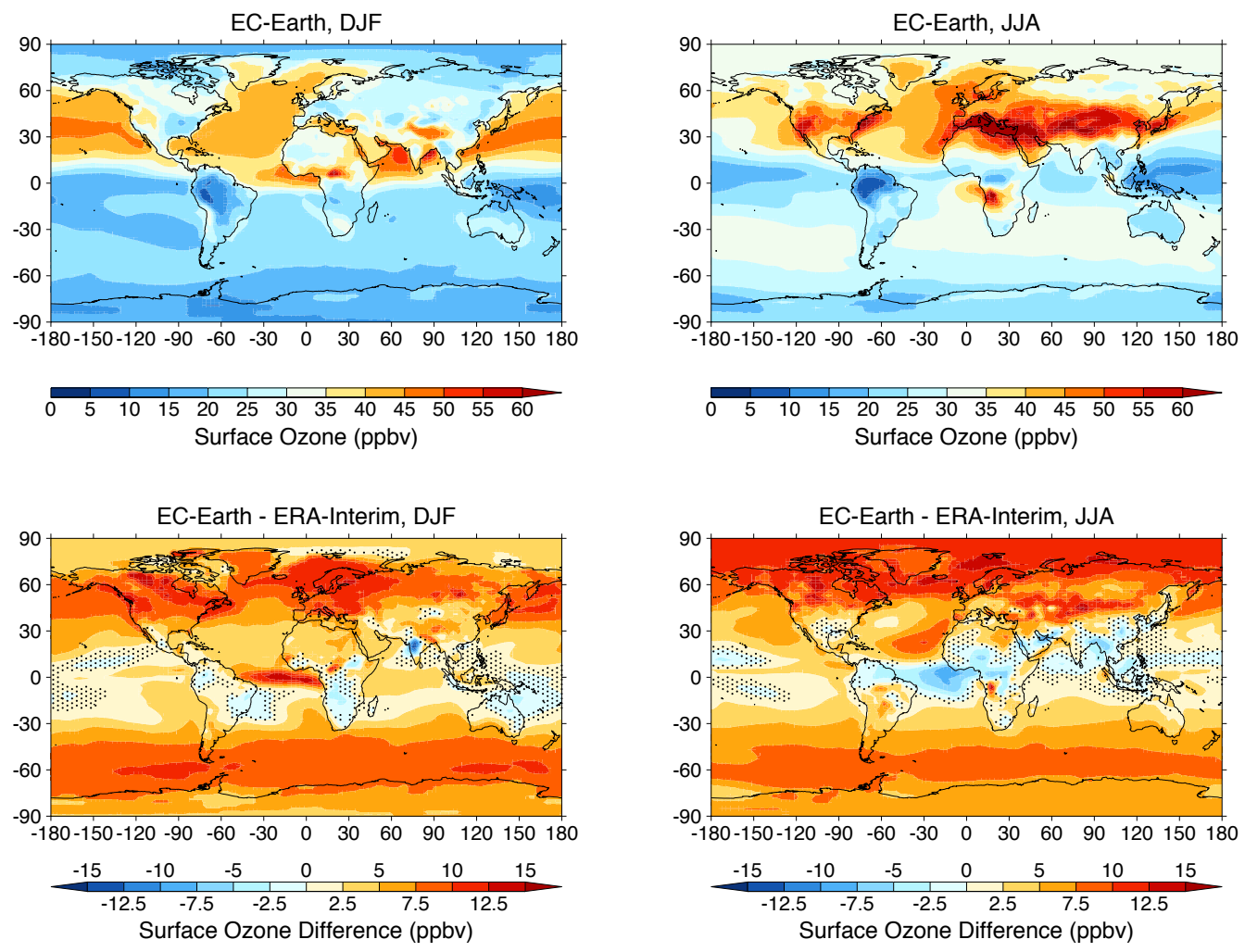

Figure 10. Surface $\mathrm{O}_{3}$ mixing ratios in the reference EC-Earth simulation (top) and the differences compared to the corresponding ERAInterim simulation (bottom) for boreal winter (left) and boreal summer (right).

At Summit (Greenland), EC-Earth is in excellent agreement with the measurements during summer and underestimates the measurements in the other seasons. At Storhofdi (Iceland), on the other hand, EC-Earth very well reproduces the measured concentrations in winter, but overestimates them in the other seasons.

The picture is different at the tropical and subtropical stations, where both simulations show an average positive bias. At Tutuila station, located in the tropics in the SH, the simulations give similar results and systematically overestimate the observations. At Mauna Loa, EC-Earth is in reasonable agreement with the observations during spring and summer and overestimates the observations during fall and winter. Here the difference with the ERA-Interim simulation is relatively small compared to the interannual variability in the results. At the other tropical and subtropical stations, ECEarth shows worse agreement with the observations than the ERA-Interim simulation, depending on the location.

EC-Earth also shows an average positive bias at the NH mid-latitude stations. Here the model overestimates the measurements especially during summer. With the exception of the high-altitude station Hohenpeissenberg (Germany), the ERA-Interim simulation is closer to the observations at these stations.

\subsection{Aerosols}

In this section the model is evaluated with regard to the simulation of aerosols. Maps of the atmospheric loads of the different aerosol components from the EC-Earth and ERAInterim simulations are presented in Fig. 12. In Table 6 we compare the corresponding global burdens, lifetimes, and dry and wet deposition rates as well as the emissions of sea salt and mineral dust with results from recent modelling studies, in particular multi-model estimates from AeroCom and ACCMIP. Results on the global budgets of the sulfate precursors DMS, MSA, and $\mathrm{SO}_{2}$ are given in Table A6.

Compared to the ERA-Interim simulation, the sulfate load in EC-Earth is on average lower in the tropics and, especially in boreal winter, higher in the extratropics. The decrease in the tropics is mainly caused by a lower chemical production (see Table A6). The increase in the extratropics is the combined effect of a higher chemical production and a longer lifetime. The loads of black carbon, organic aerosols, and nitrate are also higher at high northern latitudes in boreal winter.

Furthermore, EC-Earth gives higher sea salt loads at high latitudes, especially during local winter and spring. This is mainly due to higher emissions from the oceans (see Table 6). Since the emission rate calculated in the model depends strongly on the $10 \mathrm{~m}$ wind speed (Sect. 2.2.9), the 

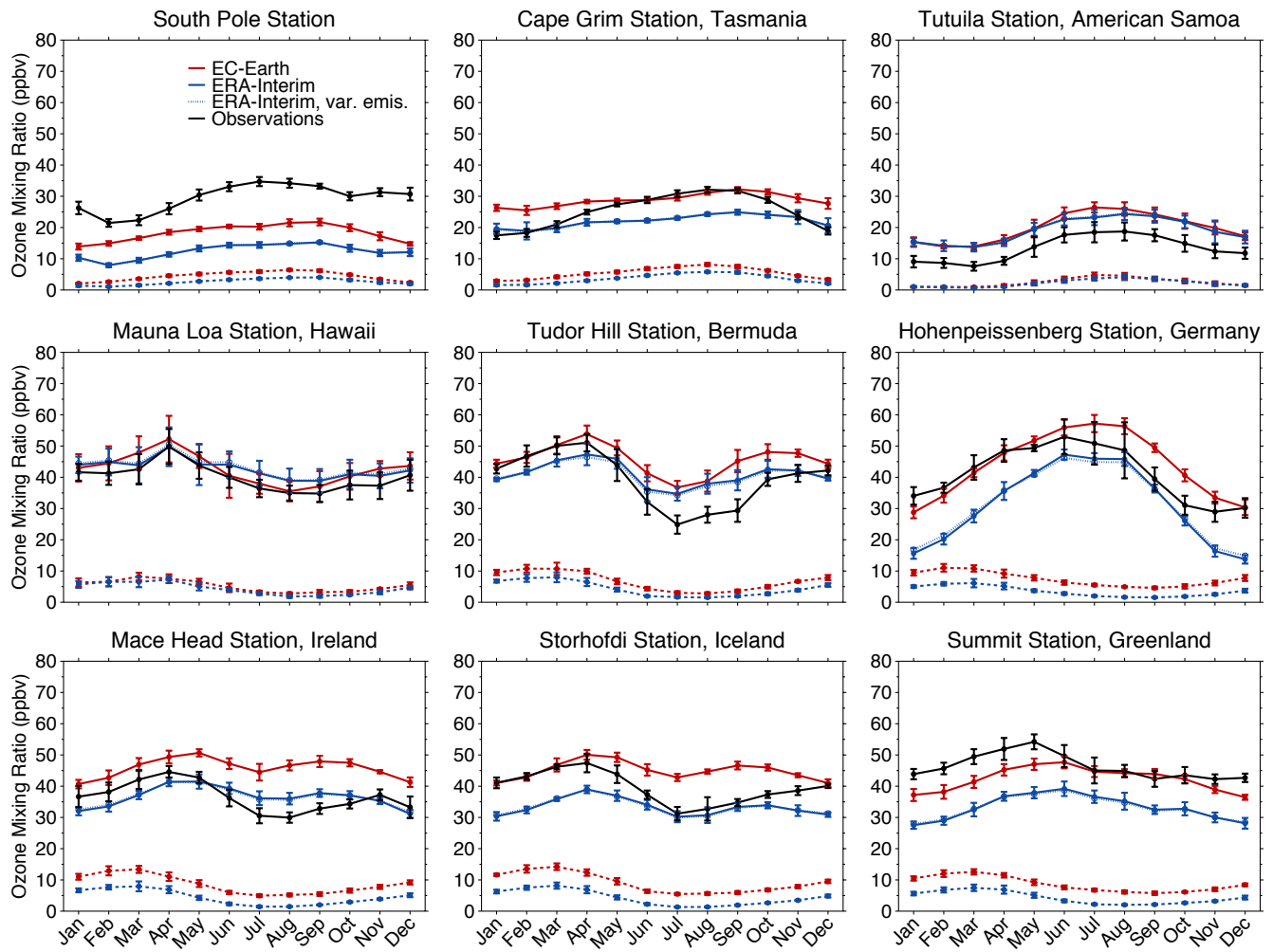

Figure 11. Comparison of monthly mean surface $\mathrm{O}_{3}$ mixing ratios from the reference EC-Earth simulation (solid red lines) and the two ERAInterim simulations (solid and dotted blue lines) against in situ measurements at a number of stations included in the NOAA GMD, WDCGG, and/or EMEP databases (solid black lines). The results from the ERA-Interim simulation with interannual variations in the emissions from anthropogenic activities and biomass burning (dotted blue lines) nearly coincide with those from the ERA-Interim simulation where these emissions are fixed to their values for the year 2000 (solid blue lines). The contributions from $\mathrm{O}_{3 \mathrm{~S}}$ are shown by the dashed lines at the bottom of each panel (red for EC-Earth, blue for ERA-Interim).

emissions at high and mid-latitudes are highest during the winter season. Moreover, small differences in surface winds over the oceans may introduce substantial differences in the emissions. A comparison of the sea salt emissions in both simulations shows that EC-Earth produces higher emissions over large parts of the northern Pacific and the Southern Ocean (not shown).

In the tropics, the differences in the aerosol distributions between the two simulations also reflect a shift in the location of the inter-tropical convergence zone (ITCZ). In particular, during boreal winter a southward shift in the aerosol loads can be observed over central Africa and the tropical Atlantic for all components except sea salt. As the mineral-dust and biomass burning emissions are the same in both simulations, this shift in the aerosol distributions is likely caused by differences in the location of the ITCZ and in the associated transport.

The global burdens of the different aerosol components from both simulations are generally on the low side of the ranges obtained in recent model intercomparison studies (see Table 6). On the other hand, their atmospheric lifetimes and the relevant dry and wet deposition rates are well within the multi-model estimates from these studies. This indicates that the emissions of aerosols and/or aerosol precursors are lower in our simulations. As can be verified in Tables 6 and A6, the emissions of sea salt and DMS in our simulations are indeed on the low side of the ranges used in AeroCom and ACCMIP, respectively. Moreover, the volcanic sulfur emissions applied in our model are substantially lower than in the ACCMIP models.

The aerosol optical depth (AOD) field from the EC-Earth simulation is quantitatively similar to the result obtained with ERA-Interim (see Fig. 13). The spatial correlation between the multi-annual mean AOD fields from the two simulations is 0.97 and the global mean AOD values differ by only $3 \%$.

EC-Earth gives somewhat higher values at high latitudes, especially during winter and spring. This is primarily due to a higher contribution from sea salt. The higher AOD values simulated by EC-Earth in the Arctic are in somewhat better agreement with ground-based and satellite measurements as well as reanalysis data (see von Hardenberg et al., 2012).

In the tropics and at mid-latitudes the AOD differences between the two simulations can be positive or negative, depending on the location and the season. During boreal winter 

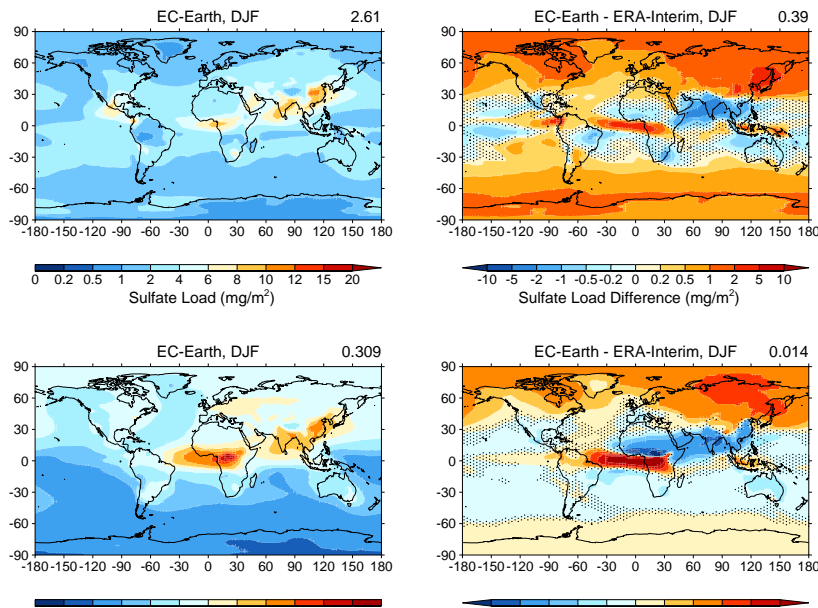

Black Carbon Load Difference $\left(\mathrm{mg} / \mathrm{m}^{2}\right)$
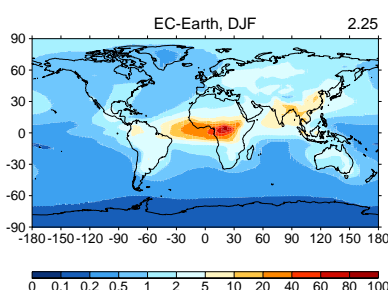
Organic Aerosol Load $\left(\mathrm{mg} / \mathrm{m}^{2}\right)$
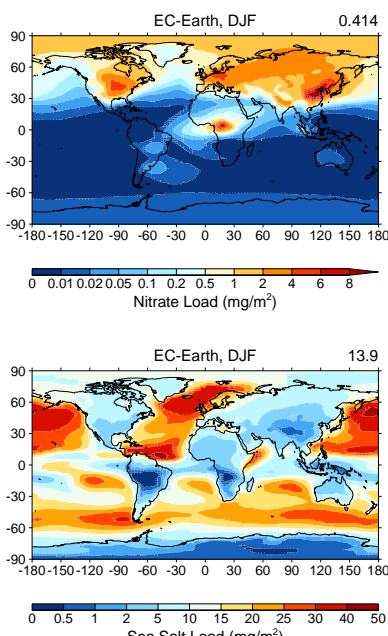

Sea Salt Load $\left(\mathrm{mg} / \mathrm{m}^{2}\right)$
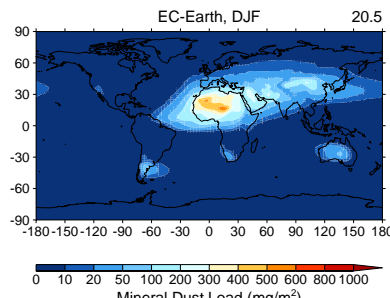

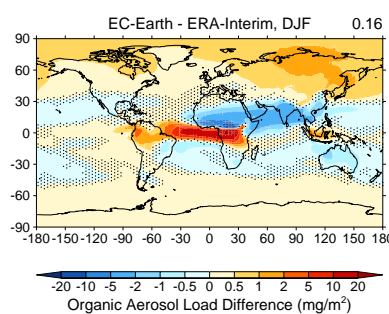

EC-Earth - ERA-Interim DJF
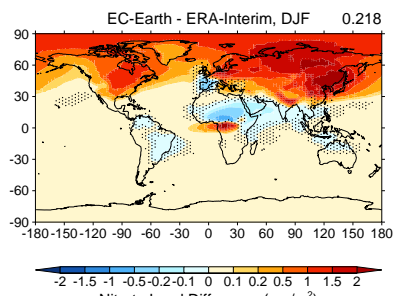

Nitrate Load Difference $\left(\mathrm{mg} / \mathrm{m}^{2}\right)$

EC-Earth - ERA-Interim, DJF

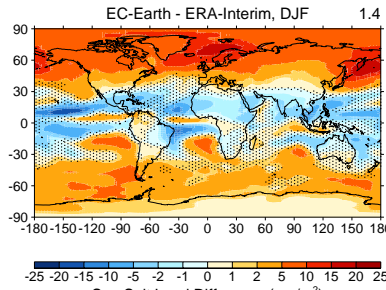

Sea Salt Load Difference $\left(\mathrm{mg} / \mathrm{m}^{2}\right)$

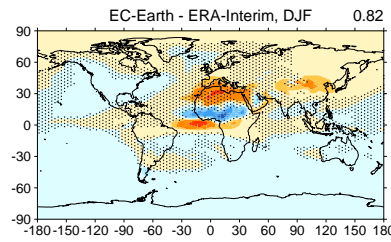

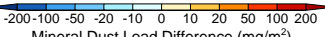
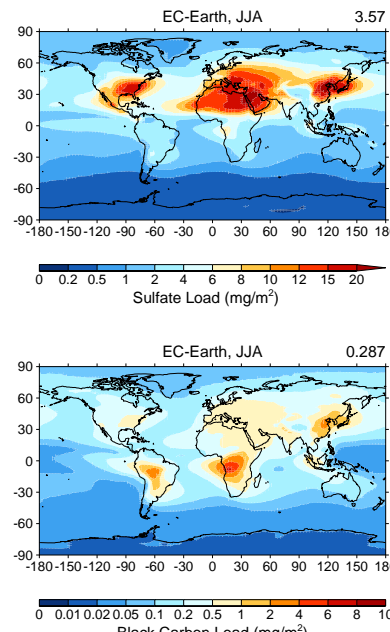

Black Carbon Load $\left(\mathrm{mg} / \mathrm{m}^{2}\right)$
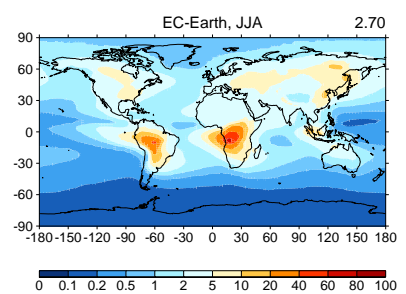
Organic Aerosol Load $\left(\mathrm{mg} / \mathrm{m}^{2}\right)$
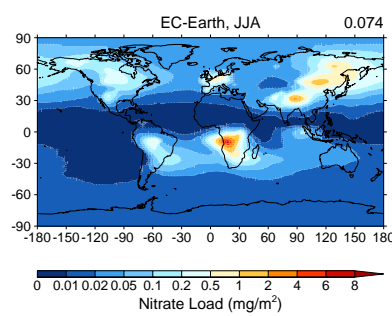

EC-Earth, JJA

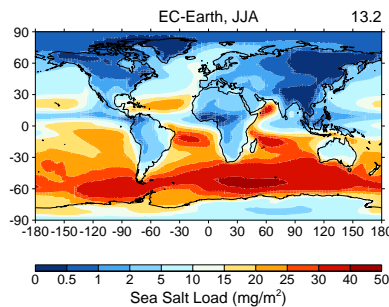

Sea Salt Load $\left(\mathrm{mg} / \mathrm{m}^{2}\right)$

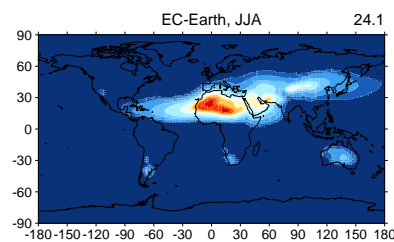

$1020 \quad 501002003004005006008001000$
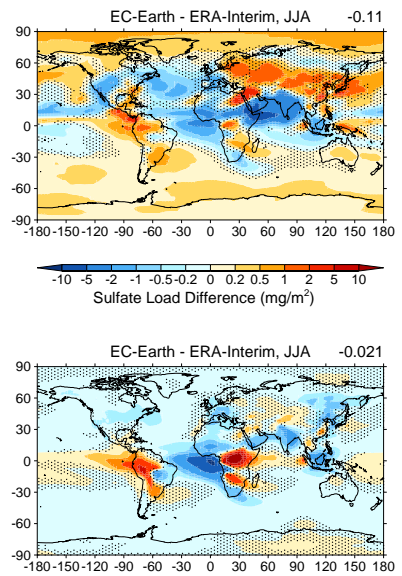

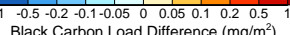

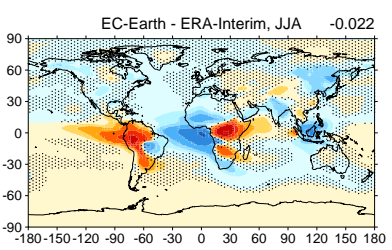

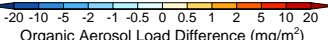

EC-Earth - ERA-Interim, JJA 0.014
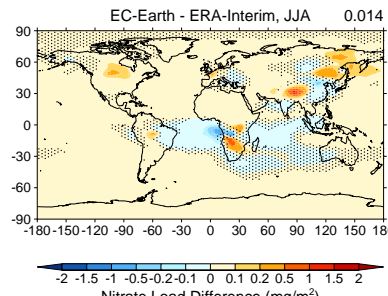

Nitrate Load Difference $\left(\mathrm{mg} / \mathrm{m}^{2}\right)$

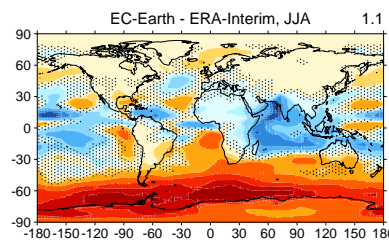

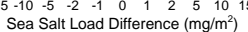

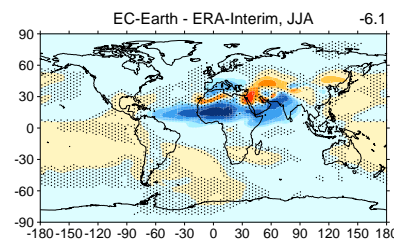

$200-100-50-20-10 \quad 0 \quad 10 \quad 10 \quad 20 \quad 50 \quad 100200$

Figure 12. Total loads of the different aerosol components in the reference EC-Earth simulation and the differences compared to the corresponding ERA-Interim simulation for boreal winter (left two columns) and boreal summer (right two columns). The global mean values of the displayed fields are indicated at the top of each panel. 
Table 6. Global budgets, burdens, and lifetimes of the different aerosol components for the reference EC-Earth simulation and the corresponding ERA-Interim simulation. Estimates of their contributions to the optical depth at $550 \mathrm{~nm}$ are also included. The results are compared with estimates from other studies.

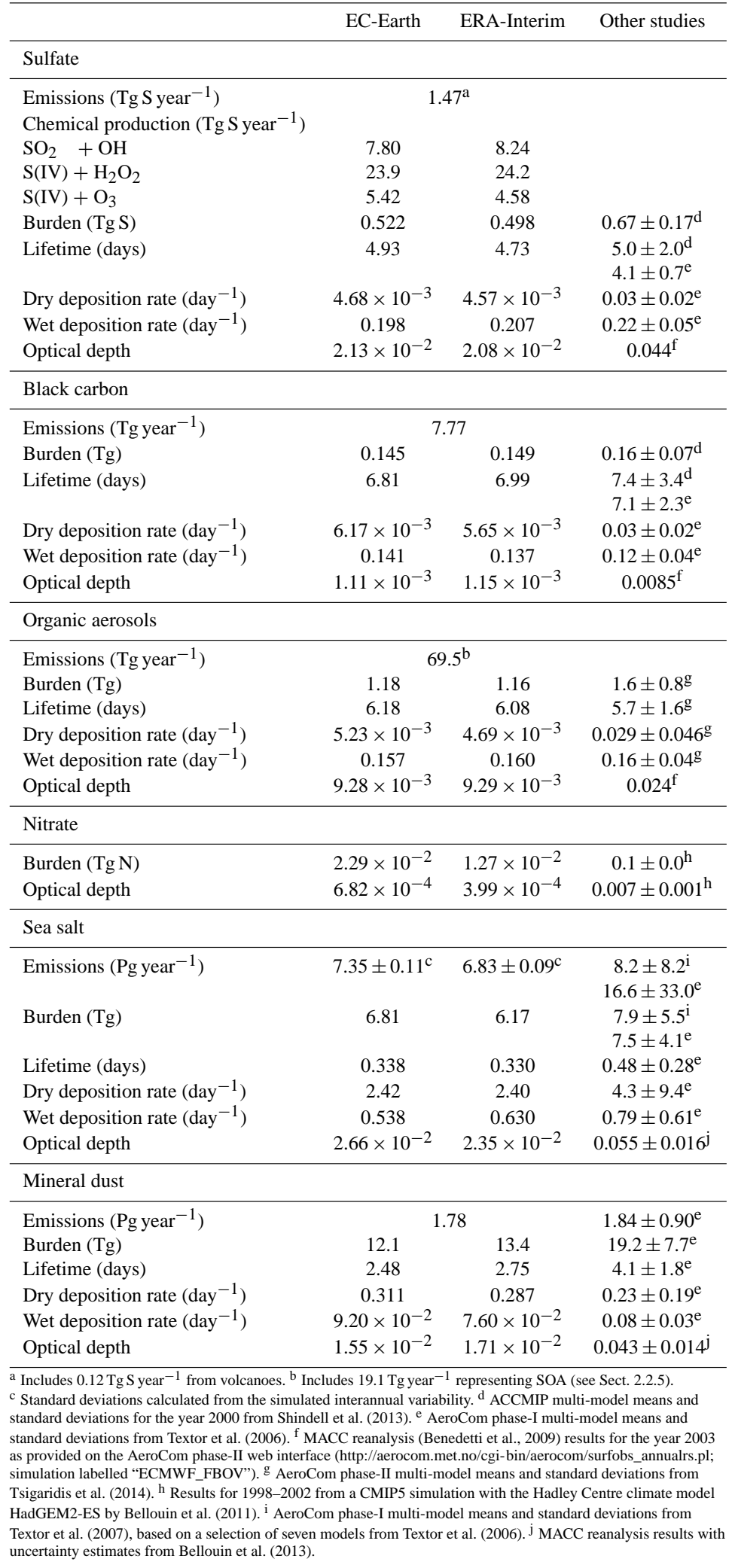



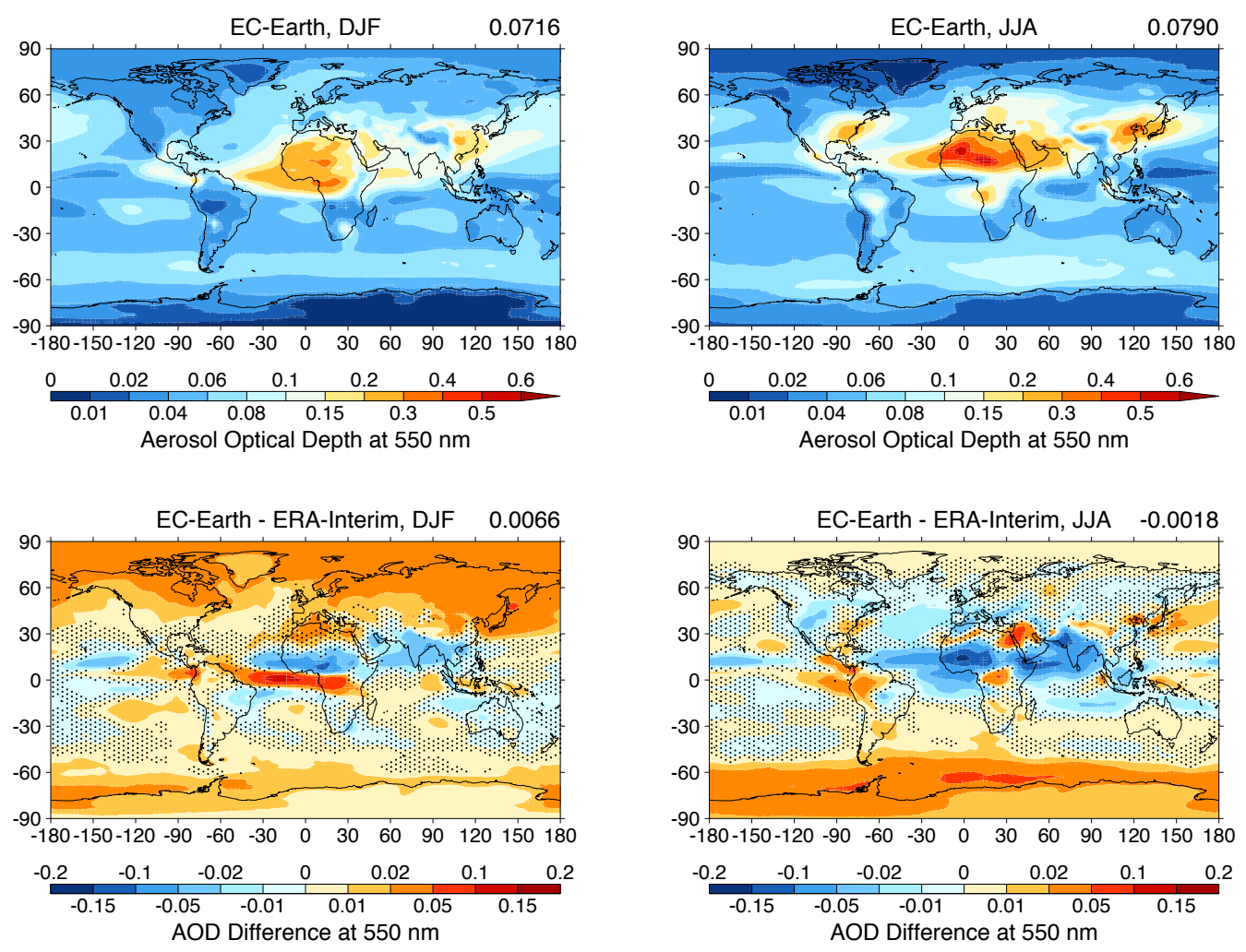

Figure 13. Aerosol optical depth at $550 \mathrm{~nm}$ in the reference EC-Earth simulation (top) and the differences compared to the corresponding ERA-Interim simulation (bottom) for boreal winter (left) and boreal summer (right). The global mean values of the displayed fields are indicated at the top of each panel.

a southward shift in the AOD pattern can be observed over central Africa and the tropical Atlantic. This is primarily due to a shift in the contributions from mineral dust and biomass burning (see Fig. A1 in the Appendix), and reflects a shift in the location of the ITCZ. During boreal summer, ECEarth gives smaller AOD values over large parts of northern Africa and the tropical Atlantic. In the NH this can mainly be attributed to a lower contribution from mineral dust, over the southern equatorial Atlantic to a lower contribution from biomass burning. In most of western Africa and the Sahel, EC-Earth produces lower AOD values than the ERA-Interim simulation in all seasons. EC-Earth also produces somewhat lower AOD values over India and the Arabian Sea from summer to winter, especially during the summer season. This is mainly caused by lower contributions from mineral dust and sulfate (see Fig. A1).

We have evaluated the AOD fields from both simulations against remote-sensing data from the Moderate Resolution Imaging Spectroradiometer (MODIS) instrument aboard the Terra and Aqua satellites, part of NASA's Earth Observing System (EOS). For this analysis, we have used the Level3 monthly gridded AOD fields from MODIS collection 5.1, which are provided at $1^{\circ} \times 1^{\circ}$ resolution. We have included the data for the years 2000-2009 and averaged the results from the Terra and Aqua data products. The resulting mean fields were subsequently coarsened to the $3^{\circ} \times 2^{\circ}$ grid of TM5.

Both simulations strongly underestimate the AOD values retrieved from MODIS over almost the entire globe (Fig. 14). The mean bias is -0.083 for EC-Earth and -0.086 for the ERA-Interim simulation, which is 53 and $54 \%$, respectively, of the retrieved mean value of 0.158 . EC-Earth gives a smaller mean bias than the ERA-Interim simulation from boreal autumn to spring, especially in the winter season (see Table A7).

There are some land regions where the simulations produce higher values than observed. This is for instance the case over large parts of Australia, which also include desert areas, in all seasons. As it is difficult to accurately retrieve AOD over deserts because of the high reflectivity of the surface, biases in these regions can be due to model biases as well as errors in the MODIS retrieval. The simulations also give higher AOD values over the southeastern United States during boreal winter and autumn, over southern parts Central America during boreal winter, over eastern parts of South America during austral winter and autumn, and over parts of South Africa during austral summer and autumn. We have checked that these biases are not caused by the fact that in the reference EC-Earth simulation and the corresponding ERA-Interim simulation the emissions from anthropogenic 

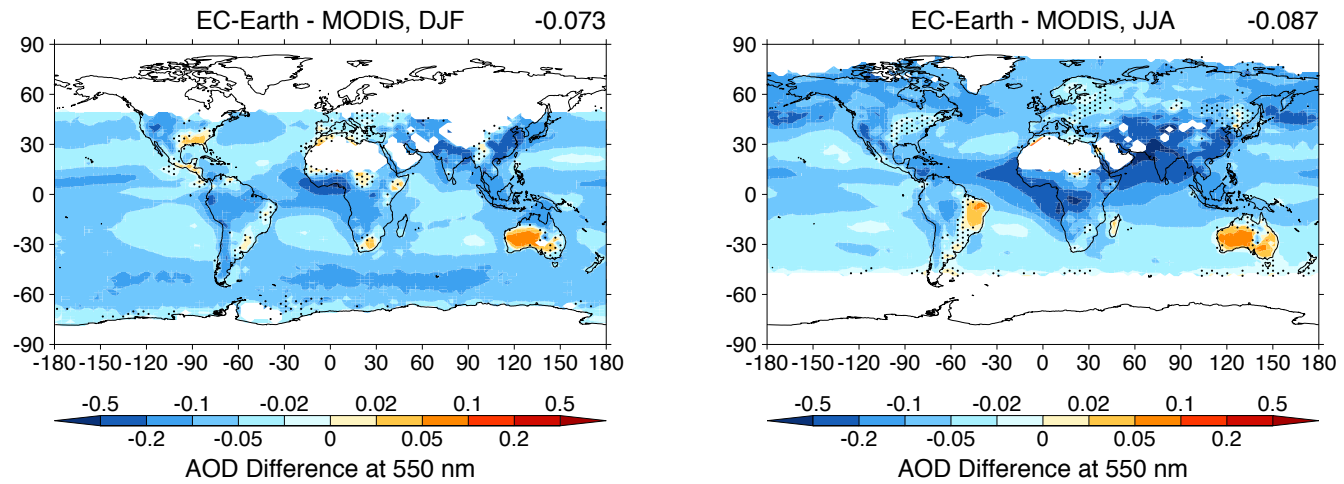

Figure 14. Difference in aerosol optical depth at $550 \mathrm{~nm}$ from the reference EC-Earth simulation compared to the MODIS Level-3 product coarsened to the same resolution and averaged over the years 2000-2009 for boreal winter (left) and boreal summer (right). Grid areas where, for all consecutive years, the MODIS data are missing for one or more months during the presented seasons are not included. The mean values of the displayed fields are indicated at the top of each panel.

activities and biomass burning were fixed to their values for the year 2000. Biases of similar magnitude are found in the ERA-Interim simulation with emissions varying from year to year. In other parts of the world, the simulated AOD values are generally much lower than the MODIS values.

In all seasons, the AOD fields from the simulations correlate well with the distributions observed by MODIS (Table A7). The spatial correlation between the simulated and observed multi-annual mean AOD fields is 0.80 for EC-Earth and 0.79 for ERA-Interim, which means that 65 and $62 \%$, respectively, of the observed spatial variability is captured by the simulations. The observed spatial distribution is slightly better represented by EC-Earth than by the ERA-Interim simulation during boreal winter and autumn, and slightly worse during boreal summer.

We have also calculated the temporal correlation between the simulated and observed monthly mean AOD values as a function of geographical location. As we have only included locations where observations are available for every month of the year, the analysis is restricted to the tropics and mid-latitudes. The resulting seasonal correlation map shows strong spatial variability where regions with high correlations are intermixed with regions with low correlation (Fig. 15, left panel). Moreover, in some regions the observed seasonal cycle is better represented by EC-Earth, in other regions by the ERA-Interim simulation (Fig. 15, right panel). For instance, EC-Earth gives higher correlations over the southern equatorial Atlantic and the southern Indian Ocean, but lower correlations over the northern equatorial Atlantic, the Arabian Sea, the Bay of Bengal, and Indonesia.

Finally, we compare the contributions from the individual aerosol components to the global mean optical depth in our simulations with estimates from an aerosol reanalysis produced within the MACC project. The MACC reanalysis system for aerosols is based on the IFS meteorological assimilation system with an integrated aerosol module (Morcrette et al., 2009) and uses MODIS retrievals of total AOD at $550 \mathrm{~nm}$ to further constrain the aerosol simulation (Benedetti et al., 2009). Because total AOD is assimilated in the reanalysis, it provides a valuable reference data set for evaluating global aerosol models.

Compared to the results from the MACC reanalysis, our simulations underestimate the global mean AOD contributions for all components (see Table 6). Both in the reanalysis and in our simulations, the components that contribute most to the global mean AOD at $550 \mathrm{~nm}$ are sea salt, sulfate, and mineral dust, followed by organic aerosols. Compared to the reanalysis results, the contributions from these components are underestimated by a factor 2 to 3 . It is important to note, however, that the distribution of AOD over the individual aerosol components in the reanalysis is also subject to model uncertainty.

\section{Discussion and conclusions}

We have integrated the atmospheric chemistry and transport model TM5 into the global climate model EC-Earth. The system allows for two-way exchange of fields between TM5 and IFS, the atmospheric GCM of EC-Earth. Here we have tested the system in one-way coupled configuration. We have carried out a decadal simulation of tropospheric chemistry and aerosols for present-day conditions, and calculated chemical budgets and climatologies of tracer concentrations and aerosol optical depth. We have evaluated the results against corresponding TM5 simulations driven offline by meteorological fields from (1) the ERA-Interim reanalysis and (2) the EC-Earth model itself, as well as against various observational data sets.

Differences in transport have been diagnosed from the simulated radon-222 concentrations. Compared to the offline simulations, the online-coupled system exhibits more efficient vertical mixing in the troposphere. This is due to 

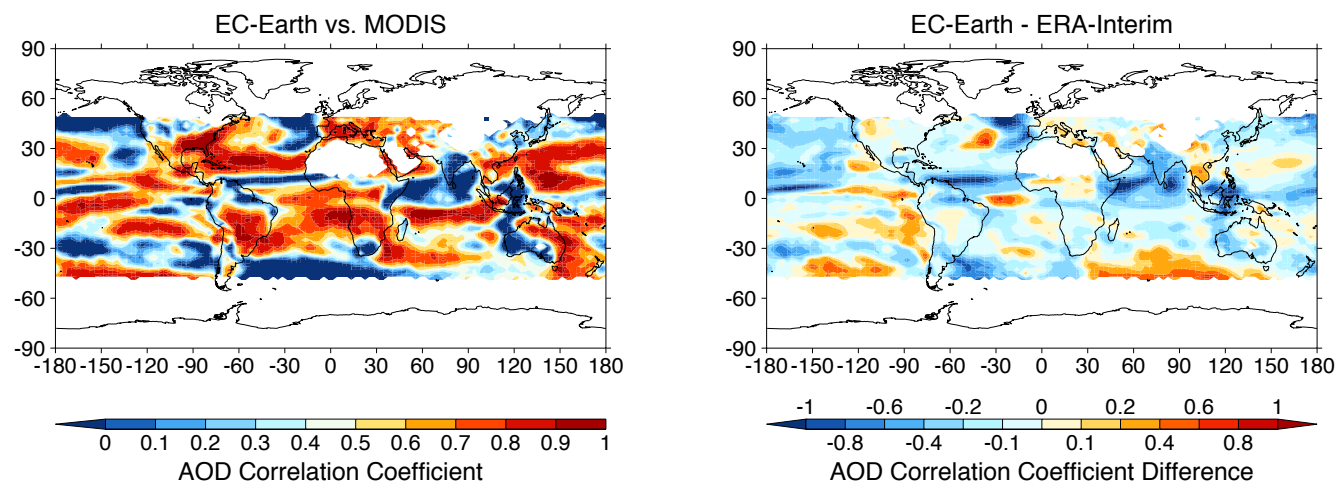

Figure 15. Linear correlation coefficient between the decadal monthly mean aerosol optical depths at $550 \mathrm{~nm}$ from the reference EC-Earth simulation and the MODIS Level-3 product coarsened to the same resolution (left), and the difference compared to the corresponding correlation coefficient for the ERA-Interim simulation (right). Grid areas where, for all consecutive years, the MODIS data are missing for one or more months are not included.

the different treatment of cumulus convection in the onlinecoupled system, in which the relevant convective fields are passed from IFS to TM5. In the offline simulations these fields are calculated diagnostically based on a somewhat outdated parameterization (Tiedtke, 1989). The stronger mixing characteristics seen in the coupled system likely reflect improvements in the convection scheme made in more recent cycles of IFS (Bechtold et al., 2008; Jung et al., 2010).

Compared to the ERA-Interim simulation, the oxidizing capacity in EC-Earth is lower in large parts of the tropical and subtropical troposphere, and higher in the extratropics. The lower oxidizing capacity in the tropics and subtropics is primarily driven by the model's cold bias in these regions, which results in a lower specific humidity. As a consequence, the atmospheric lifetime of $\mathrm{CH}_{4}$ is $7 \%$ longer in EC-Earth than in the ERA-Interim simulation: EC-Earth gives a lifetime of 9.4 years, while the ERA-Interim simulation gives 8.8 years. Both values are well within the range $9.1 \pm 0.9$ years, recently estimated by Prather et al. (2012).

Differences in vertical mixing and oxidizing capacity also affect the distribution of other chemically reactive gases such as $\mathrm{CO}$ and $\mathrm{O}_{3}$. Compared to the ERA-Interim simulation, the total chemical production and destruction of $\mathrm{CO}$ are lower in EC-Earth, resulting in very similar total amounts and a $4 \%$ longer lifetime. On the other hand, EC-Earth gives lower CO concentrations in the $\mathrm{NH}$ extratropics, due to faster chemical destruction in this region. This leads to a somewhat stronger underestimation of the surface concentrations measured by the NOAA GMD flask sampling network. In both configurations, the total chemical production of CO in TM5 is below the range of model estimates reported by Shindell et al. (2006b), suggesting that the CBM4 chemistry scheme underestimates the production of CO from NMVOCs.

The influx of $\mathrm{O}_{3}$ from the stratosphere to the troposphere is $14 \%$ higher in EC-Earth than in the ERA-Interim simulation, and is in slightly better agreement with other modelling studies as well as observational estimates. Moreover, the cold bias in EC-Earth tends to slow down the chemical destruction of $\mathrm{O}_{3}$ in the troposphere, resulting in an increase in the net chemical production of $\mathrm{O}_{3}$ in the troposphere. Furthermore, enhanced vertical mixing tends to redistribute $\mathrm{O}_{3}$ from higher to lower parts of the troposphere. Overall, the total amount of $\mathrm{O}_{3}$ in the troposphere is $6 \%$ higher in EC-Earth, in better agreement with the ranges reported in the model intercomparison studies by Stevenson et al. (2006) and Young et al. (2013). The average lifetime of tropospheric $\mathrm{O}_{3}$ increases by $7 \%$ from 23.9 days with ERA-Interim to 25.5 days in ECEarth. The latter value is higher than the multi-model range reported by Stevenson et al. (2006) and is on the high side of the model results reported by Young et al. (2013).

Overall, EC-Earth produces lower concentrations in the upper parts of the tropical and subtropical troposphere and higher concentrations in most of the lower and middle troposphere, especially in the extratropics. Similarly, EC-Earth gives higher surface concentrations in most of the world, with the exception of some regions located in the tropics and subtropics. This results in a $15 \%$ higher total deposition of $\mathrm{O}_{3}$ compared to the ERA-Interim simulation.

The simulated $\mathrm{O}_{3}$ concentrations have been evaluated against a vertically resolved, zonal, and monthly mean data set produced from satellite and ozonesonde observations (Hassler et al., 2009; www.bodeker.com) and against surface measurements from various networks. Both simulations show reasonable agreement with the observational data sets and both have their relative strengths and weaknesses depending on the location and the season. EC-Earth tends to overestimate the $\mathrm{O}_{3}$ concentrations in the lower troposphere and at the surface in the $\mathrm{NH}$ extratropics during boreal summer and fall. Note that this is partly a resolution effect. It is well known that the relatively coarse horizontal resolutions applied in the current generation of global chemistry models tends to overestimate the production of $\mathrm{O}_{3}$ in the boundary layer (Wild and Prather, 2006). During boreal winter and spring, on the other hand, as well as in the 
SH extratropics, the higher surface and lower-tropospheric concentrations produced by EC-Earth are generally in better agreement with the measurements than the results from the ERA-Interim simulation.

The aerosol climatologies from both simulations are quantitatively very similar. EC-Earth gives somewhat higher AOD values at high latitudes especially during winter and spring, mainly due to a higher contribution from sea salt. The global burdens of the various aerosol components are generally on the low side of the ranges obtained in recent model intercomparison studies like AeroCom and ACCMIP. This is partly caused by lower natural emissions, in particular of sea salt, DMS and volcanic sulfur. However, previous studies indicate that the wet removal of aerosols in TM5 may also be too fast (see Aan de Brugh et al., 2011). A comparison with AOD fields retrieved from MODIS shows that the simulations capture a large part of the spatial variability, but strongly underestimate the observed values over almost the entire globe.

In the system we have developed, the description of atmospheric chemistry and aerosols is not integrated into IFS. Instead, it is taken care of by a separate module, TM5, which is coupled to IFS through OASIS. Previously, a coupled TM5IFS system using OASIS was developed within the GEMS project (Flemming et al., 2009). However, the data exchange in that system was designed specifically for short-term forecasts and reanalysis purposes, in which chemical data assimilation plays a central role. We also needed to completely redo the technical implementation of the coupling, because the GEMS system made use of an OASIS version that is incompatible with the version used in EC-Earth.

A more recent activity is the development of the Composition-IFS (C-IFS) model within the MACC project. In C-IFS the description of atmospheric chemistry is integrated into the IFS model (Flemming et al., 2012). As part of this development, the aerosol scheme of IFS (Morcrette et al., 2009) is also being upgraded and coupled to the gasphase chemistry. The main advantages of C-IFS compared to the system we have developed are (1) that the description of chemistry and aerosols can be more tightly coupled to the relevant dynamical and physical processes described in IFS, and (2) that there is no external exchange of data. Conversely, the main advantages of our system compared to C-IFS are (1) that the tracer transport in TM5 is locally mass conserving, and (2) that TM5 can be run at a lower resolution than IFS. The latter points are crucial to enable long-term climate integrations, but are less relevant for the short-term forecast and reanalysis simulations which C-IFS has been developed for, and (3) that the TM5 module can be kept more easily up to date with the offline version.

The work presented in this study is the first step in the development of EC-Earth into an Earth system model with fully interactive chemistry and aerosols. A number of developments are planned for the near future. First, to improve the simulation of aerosol burdens and optical depths, we intend to improve the representation of natural emissions of aerosols and aerosol precursors, and revisit the description of the wet removal processes in TM5. At the same time, the calculation of photolysis rates will be updated following Williams et al. (2006, 2012) and coupled to the simulated aerosols. Moreover, the representation of heterogeneous chemistry will be improved following Huijnen et al. (2014). Another line of work focuses on improving the representation of stratospheric chemistry through simplified schemes, but this is more a long-term project.

Meanwhile, the performance and scalability of TM5 has recently been strongly improved, and will be further improved in the near future. The new, massively parallel model (named TM5-mp) is currently being implemented into the latest version of EC-Earth (version 3.0). In this system the couplings with the radiation and cloud schemes of IFS will be made, and the exchange period will be reduced from 6 to $3 \mathrm{~h}$ or less.

A parallel development is the introduction of a carbon cycle in EC-Earth, based on the dynamic vegetation model LPJGUESS (Smith et al., 2001; Weiss et al., 2014) and the biogeochemical component of NEMO. As part of these developments, various couplings will be made between TM5 and the terrestrial and marine biosphere. 


\section{Appendix A}

Table A1. Vertical distributions applied to the different emission sources. The emissions from aviation are distributed as provided in the CMIP5 emission data set.

\begin{tabular}{|c|c|c|c|c|c|c|c|}
\hline \multirow[t]{2}{*}{ Vertical distribution type } & \multirow[t]{2}{*}{ Emission sector/source } & \multicolumn{6}{|c|}{ Fraction per height range $(\%)$} \\
\hline & & $0-30 \mathrm{~m}$ & $30-100 \mathrm{~m}$ & $100-300 \mathrm{~m}$ & $300-600 \mathrm{~m}$ & $600-1000 \mathrm{~m}$ & $1000-2000 \mathrm{~m}$ \\
\hline Energy & Energy production and distribution & 0 & 10 & 70 & 20 & 0 & 0 \\
\hline Industrial & Industrial processes and combustion & 10 & 20 & 60 & 10 & 0 & 0 \\
\hline Residential & Residential and commercial combustion & 40 & 40 & 20 & 0 & 0 & 0 \\
\hline Waste & Waste treatment and disposal & 10 & 20 & 40 & 30 & 0 & 0 \\
\hline Near-surface ${ }^{a}$ & & 80 & 20 & 0 & 0 & 0 & 0 \\
\hline Surface ${ }^{b}$ & & 100 & 0 & 0 & 0 & 0 & 0 \\
\hline \multirow[t]{3}{*}{ Volcanic } & Volcanic $\mathrm{SO}_{2}$ & 0 & 0 & 10 & 30 & 40 & 20 \\
\hline & & $0-100 \mathrm{~m}$ & $100-500 \mathrm{~m}$ & $500-1000 \mathrm{~m}$ & $1000-2000 \mathrm{~m}$ & $2000-3000 \mathrm{~m}$ & $3000-6000 \mathrm{~m}$ \\
\hline & Forest fires & & & & & & \\
\hline Tropical $\left(30^{\circ} \mathrm{S}-30^{\circ} \mathrm{N}\right)$ & & 20 & 20 & 20 & 40 & 0 & 0 \\
\hline Temperate $\left(30-60^{\circ} \mathrm{S} / \mathrm{N}\right)$ & & 20 & 20 & 20 & 40 & 0 & 0 \\
\hline High-latitude $\left(60-90^{\circ} \mathrm{S} / \mathrm{N}\right)$ & & 10 & 10 & 20 & 20 & 40 & 0 \\
\hline
\end{tabular}

${ }^{\mathrm{a}}$ Includes solvent production and uses maritime transport, agricultural waste burning, grassland fires, SOA, and mineral dust. ${ }^{\mathrm{b}}$ Includes land transport, agriculture, biogenic emissions from soils and vegetation, oceanic emissions, and radon-222.

Table A2. List of stations used for the evaluation of the simulated surface radon-222 concentrations. The mean bias and root mean square errors (RMSE) in the simulated monthly mean concentrations are indicated for the online and offline EC-Earth simulations and the ERAInterim simulation. Also given are the linear correlation coefficients between the simulated and measured monthly mean concentrations. A diurnal window has been applied to the measurements, except for Cape Grim. The results for the online EC-Earth simulation and the ERA-Interim simulation are separated by a slash; the results for the offline EC-Earth simulation are shown between parentheses.

\begin{tabular}{|c|c|c|c|c|c|c|c|c|}
\hline Station & $\begin{array}{r}\text { Lat. } \\
(\mathrm{deg})\end{array}$ & $\begin{array}{l}\text { Long. } \\
\text { (deg) }\end{array}$ & $\begin{array}{r}\text { Height } \\
(\mathrm{m})\end{array}$ & $\begin{array}{l}\text { Period } \\
\text { (years) }\end{array}$ & $\begin{array}{r}\text { Window } \\
\text { (hours LT, inclusive) }\end{array}$ & $\begin{array}{r}\text { Bias } \\
\left(\mathrm{Bq} \mathrm{m}^{-3}\right)\end{array}$ & $\begin{array}{r}\text { RMSE } \\
\left(\mathrm{Bq} \mathrm{m}^{-3}\right)\end{array}$ & $\begin{array}{r}\text { Correlation } \\
\text { coefficient }\end{array}$ \\
\hline Cape Grim, Tasmania & -40.68 & 144.69 & 90 & 1991-2012 & Not applied & $\begin{array}{r}0.11 / 0.30 \\
(0.19)\end{array}$ & $\begin{array}{r}0.27 / 0.33 \\
(0.28)\end{array}$ & $\begin{array}{r}0.47 / 0.93 \\
(0.79)\end{array}$ \\
\hline Richmond, Australia & -33.62 & 150.75 & 24 & 2007-2012 & $14-18$ & $\begin{array}{r}-0.10 / 0.33 \\
(0.07)\end{array}$ & $\begin{array}{r}0.50 / 0.53 \\
(0.59)\end{array}$ & $\begin{array}{r}0.81 / 0.84 \\
(0.62)\end{array}$ \\
\hline Mauna Loa, Hawaii & 19.54 & -155.58 & 4170 & 2004-2012 & $8-10$ & $\begin{array}{r}-0.03 /-0.04 \\
(-0.03)\end{array}$ & $\begin{array}{r}0.04 / 0.04 \\
(0.04)\end{array}$ & $\begin{array}{r}0.78 / 0.78 \\
(0.78)\end{array}$ \\
\hline Gosan, Jeju Island, Korea & 33.29 & 126.16 & 70 & $2001-2010$ & $13-17$ & $\begin{array}{r}-0.97 /-0.82 \\
(-0.96)\end{array}$ & $\begin{array}{r}1.07 / 0.95 \\
(1.10)\end{array}$ & $\begin{array}{r}0.66 / 0.59 \\
(0.45)\end{array}$ \\
\hline Sado Island, Japan & 38.25 & 138.40 & 130 & $2002-2005$ & $11-16$ & $\begin{array}{r}-0.77 /-0.43 \\
(-0.62)\end{array}$ & $\begin{array}{r}0.94 / 0.73 \\
(0.84)\end{array}$ & $\begin{array}{r}-0.70 /-0.71 \\
(-0.64)\end{array}$ \\
\hline Hohenpeissenberg, Germany & 47.80 & 11.02 & 985 & 1999-2005 & $14-18$ & $\begin{array}{r}-1.30 / 0.12 \\
(-0.56)\end{array}$ & $\begin{array}{r}1.45 / 0.83 \\
(0.97)\end{array}$ & $\begin{array}{r}0.26 / 0.52 \\
(0.13)\end{array}$ \\
\hline
\end{tabular}


Table A3. Global budgets of oxidized and reduced reactive nitrogen $\left(\mathrm{Tg} \mathrm{N}_{\mathrm{Near}}{ }^{-1}\right)$ for the reference EC-Earth simulation and the corresponding ERA-Interim simulation, compared with the ACCMIP multi-model means and standard deviations for the year 2000 from Lamarque et al. (2013b). The standard deviations indicated for the $\mathrm{NO}_{\mathrm{x}}$ production by lightning in our simulations are calculated from the interannual variability.

\begin{tabular}{lccc}
\hline & EC-Earth & ERA-Interim & ACCMIP \\
\hline Oxidized nitrogen $\left(\mathrm{NO}_{\mathrm{y}}\right)$ & \multicolumn{4}{c}{ ) } & 49.0 & $49 \pm 3$ \\
\hline Total $\mathrm{NO}_{\mathrm{x}}$ emissions & 49.6 & & \\
$\mathrm{NO}_{\mathrm{x}}$ emissions by soils & \multicolumn{3}{c}{4.95} \\
$\mathrm{NO}_{\mathrm{x}}$ production by lightning & $6.45 \pm 0.06$ & $5.83 \pm 0.21$ & $6 \pm 2$ \\
$\mathrm{NO}_{\mathrm{y}}$ dry deposition & 21.1 & 20.9 & $21 \pm 7$ \\
$\mathrm{NO}_{\mathrm{y}}$ wet deposition & 29.6 & 28.8 & $29 \pm 5$ \\
$\mathrm{NO}_{\mathrm{y}}$ net chemical production & 1.02 & 0.76 & $\sim 1$ \\
\hline${\mathrm{Reduced} \mathrm{nitrogen}\left(\mathrm{NH}_{\mathrm{x}}\right)}$ & & & \\
\hline $\mathrm{NH}_{3}$ emissions & 21.9 & 22.3 & $15 \pm 6$ \\
$\mathrm{NH}_{3}$ dry deposition & 0.0 & 0.0 & $5 \pm 1$ \\
$\mathrm{NH}_{4}$ dry deposition & 8.23 & 8.14 & $7 \pm 4$ \\
$\mathrm{NH}_{3}$ wet deposition & 18.1 & 17.8 & $23 \pm 6$ \\
$\mathrm{NH}_{4}$ wet deposition & 0.24 & 0.27 & \\
$\mathrm{NH}_{\mathrm{x}}$ net chemical destruction & & & \\
\hline
\end{tabular}

Table A4. List of stations from the NOAA GMD network of flask measurements used for the evaluation of the simulated surface CO mixing ratios. The mean bias and root mean square errors (RMSE) in the simulated monthly mean mixing ratios are indicated for the reference EC-Earth simulation and the corresponding ERA-Interim simulation. Also given are the linear correlation coefficients between the simulated and measured monthly mean concentrations. The results for the EC-Earth and ERA-Interim simulations are separated by a slash.

\begin{tabular}{|c|c|c|c|c|c|c|c|}
\hline Station & $\begin{array}{l}\text { Lat. } \\
\text { (deg) }\end{array}$ & $\begin{array}{l}\text { Long. } \\
(\mathrm{deg})\end{array}$ & $\begin{array}{r}\text { Height } \\
(\mathrm{m})\end{array}$ & $\begin{array}{l}\text { Period } \\
\text { (years) }\end{array}$ & $\begin{array}{r}\text { Bias } \\
(\mathrm{ppbv})\end{array}$ & $\begin{array}{l}\text { RMSE } \\
\text { (ppbv) }\end{array}$ & $\begin{array}{c}\text { Correlation } \\
\text { coefficient }\end{array}$ \\
\hline South Pole & -89.98 & -24.80 & 2810 & 2000-2009 & $-0.2 / 0.1$ & $2.9 / 3.7$ & $0.94 / 0.91$ \\
\hline Halley Station, Antarctica & -75.58 & -26.5 & 30 & 2000-2009 & $-1.2 /-0.6$ & $2.4 / 2.7$ & $0.97 / 0.94$ \\
\hline Cape Grim, Tasmania & -40.68 & 144.69 & 94 & $2000-2009$ & $6.5 / 6.4$ & $8.8 / 8.7$ & $0.70 / 0.67$ \\
\hline Tutuila, American Samoa & -14.25 & -170.56 & 42 & 2000-2009 & $-3.9 /-4.3$ & $4.6 / 4.9$ & $0.90 / 0.86$ \\
\hline Ascension Island & -7.97 & -14.40 & 85 & 2000-2009 & $-5.2 /-3.1$ & $9.3 / 7.9$ & $0.69 / 0.83$ \\
\hline Ragged Point, Barbados & 13.16 & -59.43 & 15 & 2000-2009 & $-18.3 /-18.2$ & $18.6 / 18.7$ & $0.97 / 0.96$ \\
\hline Mariana Islands, Guam & 13.39 & 144.66 & 0 & 2000-2009 & $-19.5 /-15.9$ & $19.6 / 16.9$ & $0.99 / 0.96$ \\
\hline Mauna Loa, Hawaii & 19.54 & -155.58 & 3397 & 2000-2009 & $-18.5 /-18.4$ & $18.8 / 18.8$ & $0.98 / 0.98$ \\
\hline Izaña, Tenerife & 28.31 & -16.50 & 2373 & 2000-2009 & $-25.3 /-23.9$ & $25.9 / 24.6$ & $0.96 / 0.94$ \\
\hline Tudor Hill, Bermuda & 32.27 & -64.88 & 30 & 2002-2009 & $-29.3 /-23.2$ & $30.9 / 24.0$ & $0.97 / 0.99$ \\
\hline Terceira Island, Azores & 38.77 & -27.38 & 19 & 2000-2009 & $-33.9 /-27.6$ & $34.5 / 28.1$ & $0.95 / 0.96$ \\
\hline Mace Head, Ireland & 53.33 & -9.90 & 5 & 2000-2009 & $-30.2 /-19.9$ & $31.2 / 20.7$ & $0.97 / 0.97$ \\
\hline Cold Bay, Alaska & 55.21 & -162.72 & 21 & 2000-2009 & $-36.7 /-29.2$ & $39.0 / 31.5$ & $0.92 / 0.90$ \\
\hline Storhofdi, Iceland & 63.40 & -20.29 & 118 & 2000-2009 & $-34.0 /-23.9$ & $35.3 / 24.9$ & $0.96 / 0.97$ \\
\hline Barrow, Alaska & 71.32 & -156.61 & 11 & 2000-2009 & $-38.1 /-28.7$ & $41.0 / 31.3$ & $0.94 / 0.96$ \\
\hline Ny-Ålesund, Spitsbergen & 78.91 & 11.89 & 474 & $2000-2009$ & $-39.0 /-28.0$ & $41.0 / 29.5$ & $0.97 / 0.98$ \\
\hline Alert, Canada & 82.45 & -62.51 & 200 & 2000-2009 & $-38.9 /-29.4$ & $41.4 / 31.5$ & $0.95 / 0.97$ \\
\hline
\end{tabular}


Table A5. List of stations used for the evaluation of the simulated surface $\mathrm{O}_{3}$ mixing ratios. The mean bias and root mean square errors (RMSE) in the simulated monthly mean mixing ratios are indicated for the reference EC-Earth simulation and the corresponding ERAInterim simulation. Also given are the linear correlation coefficients between the simulated and measured monthly mean concentrations. The results for the EC-Earth and ERA-Interim simulations are separated by a slash.

\begin{tabular}{|c|c|c|c|c|c|c|c|}
\hline Station & $\begin{array}{r}\text { Lat. } \\
\text { (deg) }\end{array}$ & $\begin{array}{r}\text { Long. } \\
\text { (deg) }\end{array}$ & $\begin{array}{r}\text { Height } \\
\text { (m) }\end{array}$ & $\begin{array}{l}\text { Period } \\
\text { (years) }\end{array}$ & $\begin{array}{r}\text { Bias } \\
\text { (ppbv) }\end{array}$ & $\begin{array}{l}\text { RMSE } \\
\text { (ppbv) }\end{array}$ & $\begin{array}{c}\text { Correlation } \\
\text { coefficient }\end{array}$ \\
\hline South Pole & -89.98 & -24.80 & 2810 & 2000-2009 & $-11.2 /-17.1$ & $11.6 / 17.3$ & $0.70 / 0.94$ \\
\hline Neumayer, Antarctica & -70.65 & -8.25 & 42 & 2000-2009 & $-3.3 /-10.5$ & $5.6 / 11.1$ & $0.86 / 0.97$ \\
\hline Syowa, Antarctica & -69.00 & 39.58 & 16 & 2000-2009 & $-2.8 /-11.1$ & $4.7 / 11.4$ & $0.91 / 0.99$ \\
\hline Cape Grim, Tasmania & -40.68 & 144.68 & 94 & 2000-2009 & $3.5 /-3.3$ & $5.0 / 4.9$ & $0.88 / 0.89$ \\
\hline Cape Verde & 16.85 & -24.87 & 10 & 2006-2009 & $11.1 / 5.9$ & $12.5 / 7.3$ & $0.31 / 0.68$ \\
\hline Mauna Loa, Hawaii & 19.54 & -155.58 & 3397 & 2000-2009 & $2.6 / 2.7$ & $3.0 / 3.1$ & $0.95 / 0.96$ \\
\hline Assekrem, Algeria & 23.27 & 5.63 & 2710 & 2000-2001, 2003-2009 & $9.0 / 5.1$ & $9.5 / 5.6$ & $0.66 / 0.78$ \\
\hline Mount Everest, Nepal & 27.96 & 86.82 & 5079 & $2006-2009$ & $10.3 / 8.9$ & $12.1 / 10.5$ & $0.78 / 0.81$ \\
\hline Izaña, Tenerife & 28.30 & -16.50 & 2367 & 2000-2009 & $10.6 / 2.7$ & $11.6 / 3.9$ & $0.76 / 0.83$ \\
\hline Zugspitze, Germany & 47.42 & 10.98 & 2960 & 2000-2002 & $7.9 / 0.1$ & $8.7 / 3.5$ & $0.90 / 0.90$ \\
\hline Hohenpeissenberg, Germany & 47.80 & 11.02 & 985 & 2000-2007 & $2.8 /-10.2$ & $5.5 / 11.6$ & $0.88 / 0.91$ \\
\hline Mace Head, Ireland & 53.33 & -9.90 & 25 & 2000-2009 & $9.3 / 0.0$ & $10.2 / 4.1$ & $0.39 / 0.49$ \\
\hline Storhofdi, Iceland & 63.40 & -20.29 & 118 & 2003-2009 & $5.5 /-6.2$ & $7.2 / 7.1$ & $0.40 / 0.69$ \\
\hline Barrow, Alaska & 71.32 & -156.61 & 11 & 2000-2009 & $2.5 /-4.5$ & $8.3 / 8.0$ & $-0.26 /-0.16$ \\
\hline Summit, Greenland & 72.58 & -38.48 & 3216 & 2000-2009 & $-4.0 /-13.1$ & $5.2 / 13.5$ & $0.63 / 0.68$ \\
\hline
\end{tabular}


Table A6. Global budgets of DMS, MSA, $\mathrm{SO}_{2}$ and total reactive sulfur together with the global burden and lifetime of $\mathrm{SO}_{2}$ for the reference EC-Earth simulation and the corresponding ERA-Interim simulation. For comparison we have also included ACCMIP multi-model means and standard deviations of emissions and depositions for the year 2000 from Lamarque et al. (2013b). For the gas-phase $\mathrm{SO}_{2}$ and aqueousphase $\mathrm{S}(\mathrm{IV})$ oxidation reactions, which result in the production of $\mathrm{SO}_{4}$, the numbers between parentheses give the separate contributions from $90-30^{\circ} \mathrm{S}, 30^{\circ} \mathrm{S}-30^{\circ} \mathrm{N}$, and $30-90^{\circ} \mathrm{N}$.

\begin{tabular}{|c|c|c|c|}
\hline & EC-Earth & ERA-Interim & ACCMIP \\
\hline \multicolumn{4}{|l|}{ DMS } \\
\hline Emissions ( $\left.\operatorname{Tg~S~year~}^{-1}\right)$ & $19.4 \pm 0.2^{*}$ & $19.1 \pm 0.3^{*}$ & $23 \pm 5$ \\
\hline \multicolumn{4}{|l|}{ Chemical destruction $\left(\mathrm{Tg} \mathrm{S}\right.$ year $\left.^{-1}\right)$} \\
\hline $\mathrm{DMS}+\mathrm{OH}$ & 14.4 & 14.5 & \\
\hline $\mathrm{DMS}+\mathrm{NO}_{3}$ & 4.93 & 4.60 & \\
\hline \multicolumn{4}{|l|}{ MSA } \\
\hline \multicolumn{4}{|l|}{ Chemical production $\left(\mathrm{Tg} \mathrm{S}_{\text {year }}{ }^{-1}\right)$} \\
\hline $\mathrm{DMS}+\mathrm{OH}$ & 1.87 & 1.79 & \\
\hline Wet deposition ( $\mathrm{Tg} \mathrm{S}$ year $\left.{ }^{-1}\right)$ & 1.87 & 1.79 & $\sim 2$ \\
\hline \multicolumn{4}{|l|}{$\mathrm{SO}_{2}$} \\
\hline Total emissions (Tg S year ${ }^{-1}$ ) & \multicolumn{2}{|c|}{57.2} & $65 \pm 2$ \\
\hline Volcanic emissions $\left(\mathrm{Tg} \mathrm{S}\right.$ year $\left.{ }^{-1}\right)$ & \multicolumn{2}{|c|}{4.67} & $\sim 12 \pm 2$ \\
\hline \multicolumn{4}{|l|}{ Chemical production $\left(\mathrm{Tg} \mathrm{S}_{\text {year }}{ }^{-1}\right.$ ) } \\
\hline $\mathrm{DMS}+\mathrm{OH}$ & 12.6 & 12.7 & \\
\hline $\mathrm{DMS}+\mathrm{NO}_{3}$ & 4.93 & 4.60 & \\
\hline \multicolumn{4}{|l|}{ Chemical destruction $\left(\operatorname{Tg~S~year~}{ }^{-1}\right)$} \\
\hline $\mathrm{SO}_{2}+\mathrm{OH}$ & $\begin{array}{c}7.80 \\
(0.43 / 3.84 / 3.53)\end{array}$ & $\begin{array}{c}8.24 \\
(0.34 / 4.39 / 3.52)\end{array}$ & \\
\hline $\mathrm{S}(\mathrm{IV})+\mathrm{H}_{2} \mathrm{O}_{2}$ & $\begin{array}{c}23.9 \\
(2.75 / 12.7 / 8.46)\end{array}$ & $\begin{array}{c}24.2 \\
(2.63 / 13.4 / 8.11)\end{array}$ & \\
\hline $\mathrm{S}(\mathrm{IV})+\mathrm{O}_{3}$ & $\begin{array}{c}5.42 \\
(1.01 / 2.58 / 1.83)\end{array}$ & $\begin{array}{c}4.58 \\
(0.91 / 2.02 / 1.64)\end{array}$ & \\
\hline Dry deposition $\left(\mathrm{Tg}\right.$ S year $\left.{ }^{-1}\right)$ & 26.1 & 26.3 & \\
\hline Wet deposition ( $\mathrm{Tg} \mathrm{S}$ year ${ }^{-1}$ ) & 11.5 & 11.2 & \\
\hline Burden $(\operatorname{Tg} S)$ & 0.317 & 0.261 & \\
\hline Lifetime (days) & 1.55 & 1.28 & \\
\hline \multicolumn{4}{|l|}{ Total reactive sulfur } \\
\hline Emissions (Tg S year $\left.{ }^{-1}\right)$ & 78.1 & 77.8 & $89 \pm 6$ \\
\hline Dry deposition (Tg S year $\left.{ }^{-1}\right)$ & 27.0 & 27.2 & $37 \pm 10$ \\
\hline Wet deposition $\left(\mathrm{Tg} \mathrm{S}\right.$ year $\left.^{-1}\right)$ & 51.1 & 50.7 & $52 \pm 8$ \\
\hline
\end{tabular}

Table A7. Mean biases and linear correlation coefficients between the time averaged AOD fields from the simulations and the MODIS Level-3 product coarsened to the same resolution and averaged over the years 2000-2009. Grid areas where, for all consecutive years, the MODIS data are missing for one or more months during the year or season of interest have not been included in the calculations. The results for the EC-Earth and ERA-Interim simulations are separated by a slash.

\begin{tabular}{lccc}
\hline Season & Mean bias & Correlation coefficient & Observed area (\%) \\
\hline Annual & $-0.083 /-0.086$ & $0.80 / 0.79$ & 71.8 \\
DJF & $-0.073 /-0.080$ & $0.76 / 0.72$ & 82.2 \\
MAM & $-0.093 /-0.095$ & $0.78 / 0.78$ & 82.1 \\
JJA & $-0.087 /-0.085$ & $0.72 / 0.78$ & 84.1 \\
SON & $-0.078 /-0.080$ & $0.62 / 0.60$ & 84.8 \\
\hline
\end{tabular}



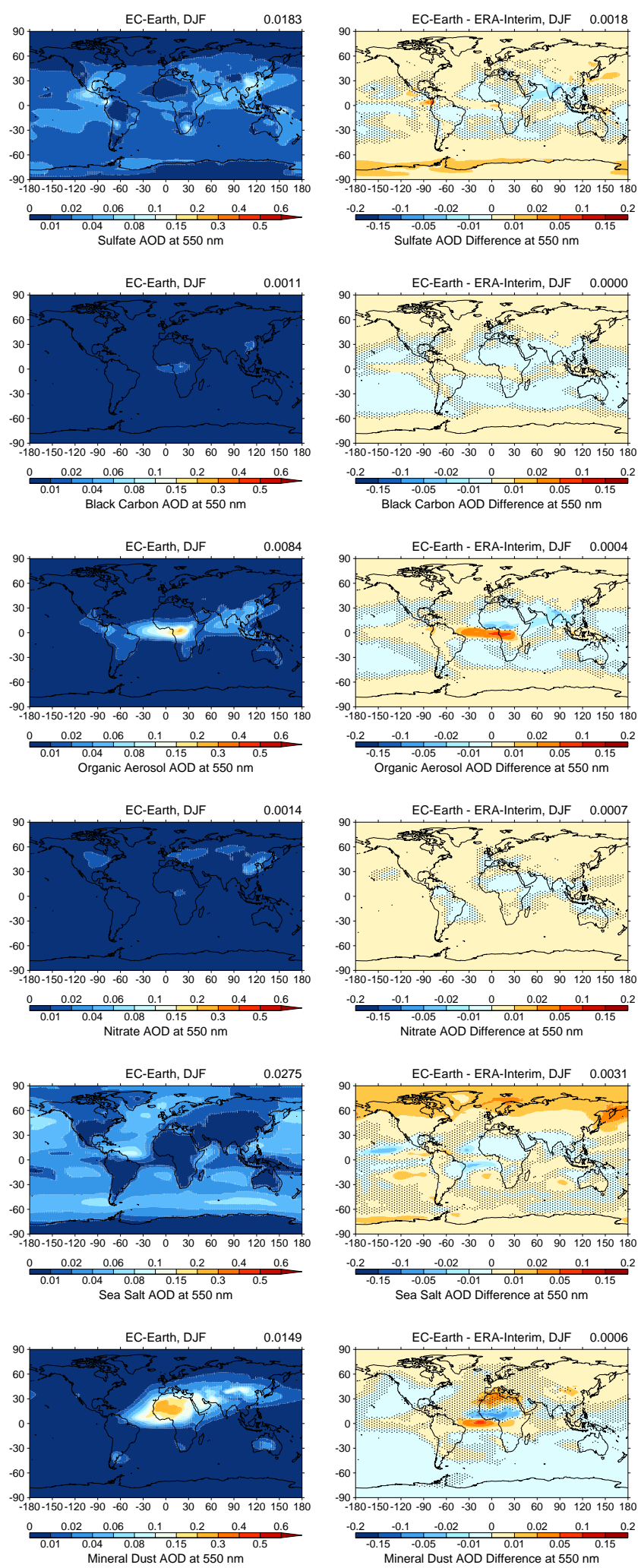
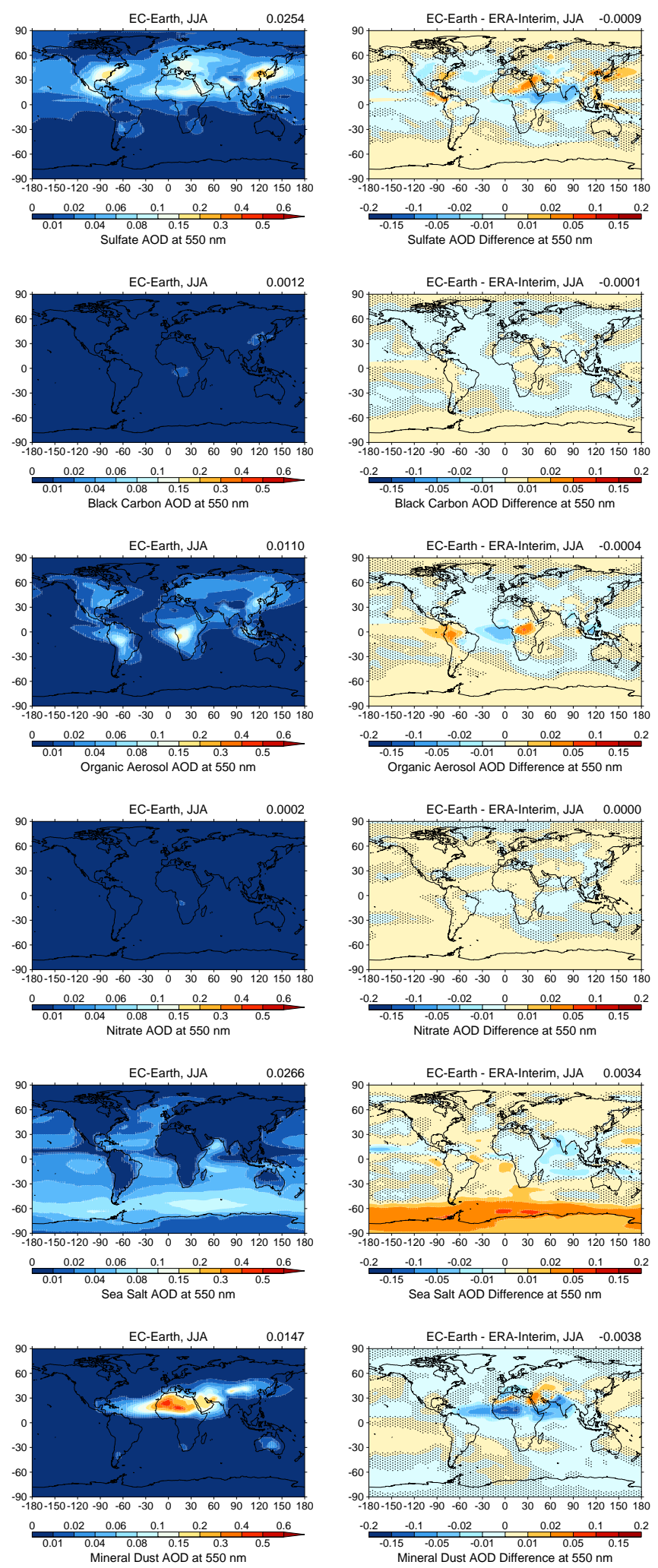

Figure A1. Contributions from the different aerosol components to the aerosol optical depth at $550 \mathrm{~nm}$ in the reference EC-Earth simulation and the differences compared to the corresponding ERA-Interim simulation for boreal winter (left two columns) and boreal summer (right two columns). The global mean values of the displayed fields are indicated at the top of each panel. 
Acknowledgements. The authors thank Klaus Wyser from the Swedish Meteorological and Hydrological Institute (SMHI) for providing the IFS-NEMO restart fields used to initialize the online EC-Earth simulations and Tido Semmler for providing IFS model-level output from an EC-Earth simulation performed by the Irish National Meteorological Service. The authors also thank Greg Bodeker (Bodeker Scientific) and Birgit Hassler (NOAA) for providing the combined vertical ozone profile database, and the MODIS science team for providing the Level-3 monthly AOD fields from MODIS collection 5.1. The EC-Earth and TM5 simulations for this study were performed on ECMWF's high-performance computing facility.

Edited by: O. Morgenstern

\section{References}

Aan de Brugh, J. M. J.: The Generic Aerosol Optics Toolbox: an aerosol optics module for any atmospheric model, in: Aerosol processes for the Netherlands, Ph.D. Thesis, Wageningen University, 117-134, 2013.

Aan de Brugh, J. M. J., Schaap, M., Vignati, E., Dentener, F., Kahnert, M., Sofiev, M., Huijnen, V., and Krol, M. C.: The European aerosol budget in 2006, Atmos. Chem. Phys., 11, 1117-1139, doi:10.5194/acp-11-1117-2011, 2011.

Andres, R. J. and Kasgnoc, A. D.: A time-averaged inventory of subaerial volcanic sulfur emissions, J. Geophys. Res., 103, 25251-25261, 1998.

Arblaster, J. M. and Meehl, G. A.: Contributions of external forcings to Southern Annular Mode trends, J. Climate, 19, 28962905, 2006.

Arfeuille, F., Luo, B. P., Heckendorn, P., Weisenstein, D., Sheng, J. X., Rozanov, E., Schraner, M., Brönnimann, S., Thomason, L. W., and Peter, T.: Modeling the stratospheric warming following the Mt. Pinatubo eruption: uncertainties in aerosol extinctions, Atmos. Chem. Phys., 13, 11221-11234, doi:10.5194/acp13-11221-2013, 2013.

Arneth, A., Harrison, S. P., Zaehle, S., Tsigaridis, K., Menon, S., Bartlein, P. J., Feichter, J., Korhola, A., Kulmala, M., O’Donnell, D., Schurgers, G., Sorvari, S., and Vesala, T.: Terrestrial biogeochemical feedbacks in the climate system, Nat. Geosci., 3, 525532, 2010.

Balkanski, Y. J., Jacob, D. J., Gardner, G. M., Graustein, W. C., and Turekian, K. K.: Transport and residence times of tropospheric aerosols inferred from a global three-dimensional simulation of ${ }^{210} \mathrm{~Pb}$, J. Geophys. Res., 98, 20573-20586, 1993.

Bechtold, P., Köhler, M., Jung, T., Doblas-Reyes, F., Leutbecher, M., Rodwell, M. J., Vitart, F., and Balsamo, G.: Advances in simulating atmospheric variability with the ECMWF model: From synoptic to decadal time-scales, Q. J. R. Meteorol. Soc., 134, 1337-1351, 2008.

Bellouin, N., Rae, J., Jones, A., Johnson, C., Haywood, J., and Boucher, O.: Aerosol forcing in the Climate Model Intercomparison Project (CMIP5) simulations by HadGEM2-ES and the role of ammonium nitrate, J. Geophys. Res., 116, D20206, doi:10.1029/2011JD016074, 2011.

Bellouin, N., Quaas, J., Morcrette, J.-J., and Boucher, O.: Estimates of aerosol radiative forcing from the MACC re-analysis,
Atmos. Chem. Phys., 13, 2045-2062, doi:10.5194/acp-13-20452013, 2013.

Benedetti, A., Morcrette, J.-J., Boucher, O., Dethof, A., Engelen, R. J., Fisher, M., Flentje, H., Huneeus, N., Jones, L., Kaiser, J. W., Kinne, S., Mangold, A., Razinger, M., Simmons, A. J., and Suttie, M.: Aerosol analysis and forecast in the European Centre for Medium-Range Weather Forecasts Integrated Forecast System: 2. Data assimilation, J. Geophys. Res., 114, D13205, doi:10.1029/2008JD011115, 2009.

Bieser, J., Aulinger, A., Matthias, V., Quante, M., and Builtjes, P.: SMOKE for Europe - adaptation, modification and evaluation of a comprehensive emission model for Europe, Geosci. Model Dev., 4, 47-68, doi:10.5194/gmd-4-47-2011, 2011.

Bond, T. C., Doherty, S. J., Fahey, D. W., Forster, P. M., Berntsen, T., DeAngelo, B. J., Flanner, M. G., Ghan, S., Kärcher, B., Koch, D., Kinne, S., Kondo, Y., Quinn, P. K., Sarofim, M. C., Schultz, M. G., Schulz, M., Venkataraman, C., Zhang, H., Zhang, S., Bellouin, N., Guttikunda, S. K., Hopke, P. K., Jacobson, M. Z., Kaiser, J. W., Klimont, Z., Lohmann, U., Schwarz, J. P., Shindell, D., Storelvmo, T., Warren, S. G., and Zender, C. S.: Bounding the role of black carbon in the climate system: A scientific assessment, J. Geophys. Res., 118, 5380-5552, 2013.

Boucher, O., Randall, D., Artaxo, P., Bretherton, C., Feingold, G., Forster, P., Kerminen, V.-M., Kondo, Y., Liao, H., Lohmann, U., Rasch, P., Satheesh, S. K., Sherwood, S., Stevens, B., and Zhang, X. Y.: Clouds and aerosols, in: Climate Change 2013: The Physical Science Basis. Contribution of Working Group I to the Fifth Assessment Report of the Intergovernmental Panel on Climate Change, edited by: Stocker, T. F., Qin, D., Plattner, G.-K., Tignor, M., Allen, S. K., Boschung, J., Nauels, A., Xia, Y., Bex V., and Midgley P. M., Cambridge University Press, Cambridge, United Kingdom and New York, NY, USA, 571-657, 2013.

Bouwman, A. F., Lee, D. S., Asman, W. A. H., Dentener, F. J., van der Hoek, K. W., and Olivier, J. G. J.: A global high-resolution emission inventory for ammonia, Global Biogeochem. Cy., 11, 561-587, 1997.

Bregman, B., Segers, A., Krol, M., Meijer, E., and van Velthoven, P.: On the use of mass-conserving wind fields in chemistry-transport models, Atmos. Chem. Phys., 3, 447-457, doi:10.5194/acp-3447-2003, 2003.

Cariolle, D. and Teyssèdre, H.: A revised linear ozone photochemistry parameterization for use in transport and general circulation models: multi-annual simulations, Atmos. Chem. Phys., 7, 2183 2196, doi:10.5194/acp-7-2183-2007, 2007.

Chambers, S., Zahorowski, W., Matsumoto, K., and Uematsu, M.: Seasonal variability of radon-derived fetch regions for Sado Island, Japan, based on 3 years of observations: 2002-2004, Atmos. Environ., 43, 271-279, 2009.

Chambers, S. D., Zahorowski, W., Williams, A. G., Crawford, J., and Griffiths, A. D.: Identifying tropospheric baseline air masses at Mauna Loa Observatory between 2004 and 2010 using Radon222 and back trajectories, J. Geophys. Res., 118, 992-1004, 2013.

Ciais, P., Sabine, C., Bala, G., Bopp, L., Brovkin, V., Canadell, J., Chhabra, A., DeFries, R., Galloway, J., Heimann, M., Jones, C., Le Quéré, C., Myneni, R. B., Piao, S., and Thornton, P.: Carbon and Other Biogeochemical Cycles, in: Climate Change 2013: The Physical Science Basis. Contribution of Working Group I to the Fifth Assessment Report of the Intergovernmental Panel 
on Climate Change, edited by: Stocker, T. F., Qin, D., Plattner, G.-K., Tignor, M., Allen, S. K., Boschung, J., Nauels, A., Xia, Y., Bex, V., and Midgley, P. M., Cambridge University Press, Cambridge, United Kingdom and New York, NY, USA, 465570, 2013

Cionni, I., Eyring, V., Lamarque, J. F., Randel, W. J., Stevenson, D. S., Wu, F., Bodeker, G. E., Shepherd, T. G., Shindell, D. T., and Waugh, D. W.: Ozone database in support of CMIP5 simulations: results and corresponding radiative forcing, Atmos. Chem. Phys., 11, 11267-11292, doi:10.5194/acp-11-11267-2011, 2011.

Dameris, M. and Jöckel, P.: Numerical modeling of climatechemistry connections: Recent developments and future changes, Atmosphere, 4, 132-156, 2013.

Dana, M. T. and Hales, J. M.: Statistical aspects of the washout of polydisperse aerosols, Atmos. Environ., 10, 45-50, 1976.

Dee, D. P., Uppala, S. M., Simmons, A. J., Berrisford, P., Poli, P., Kobayashi, S., Andrae, U., Balmaseda, M. A., Balsamo, G., Bauer, P., Bechtold, P., Beljaars, A. C. M., van de Berg, L., Bidlot, J., Bormann, N., Delsol, C., Dragani, R., Fuentes, M., Geer, A. J., Haimberger, L., Healy, S. B., Hersbach, H., Hólm, E. V., Isaksen, L., Kållberg, P., Köhler, M., Matricardi, M., McNally, A. P., Monge-Sanz, B. M., Morcrette, J.-J., Park, B.-K., Peubey, C., de Rosnay, P., Tavolato, C., Thépaut, J.-N., and Vitart, F.: The ERA-Interim reanalysis: configuration and performance of the data assimilation system, Q. J. R. Meteorol. Soc., 137, 553-597, 2011.

de Meij, A., Krol, M., Dentener, F., Vignati, E., Cuvelier, C., and Thunis, P.: The sensitivity of aerosol in Europe to two different emission inventories and temporal distribution of emissions, Atmos. Chem. Phys., 6, 4287-4309, doi:10.5194/acp-6-4287-2006, 2006.

Dentener, F. J. and Crutzen, P. J.: Reaction of $\mathrm{N}_{2} \mathrm{O}_{5}$ on tropospheric aerosols: Impact on the global distributions of $\mathrm{NO}_{\mathrm{x}}, \mathrm{O}_{3}$, and $\mathrm{OH}$, J. Geophys. Res., 98, 7149-7163, 1993.

Dentener, F., Feichter, J., and Jeuken, A.: Simulation of the transport of $\mathrm{Rn}^{222}$ using on-line and off-line global models at different horizontal resolutions: a detailed comparison with measurements, Tellus B, 51, 573-602, 1999.

Dentener, F., Kinne, S., Bond, T., Boucher, O., Cofala, J., Generoso, S., Ginoux, P., Gong, S., Hoelzemann, J. J., Ito, A., Marelli, L., Penner, J. E., Putaud, J.-P., Textor, C., Schulz, M., van der Werf, G. R., and Wilson, J.: Emissions of primary aerosol and precursor gases in the years 2000 and 1750 prescribed data-sets for AeroCom, Atmos. Chem. Phys., 6, 4321-4344, doi:10.5194/acp-64321-2006, 2006.

Ehhalt, D., Prather, M., Dentener, F., Derwent, R., Dlugokencky, E., Holland, E., Isaksen, I., Katima, J., Kirchhoff, V., Matson, P., Midgley, P., and Wang, M.: Atmospheric chemistry and greenhouse gases, in: Climate Change 2001: The Scientific Basis. Contribution of Working Group I to the Third Assessment Report of the Intergovernmental Panel on Climate Change, edited by: Houghton, J. T., Ding, Y., Griggs, D. J., Noguer, M., van der Linden, P. J., Dai, X., Maskell, K., and Johnson, C. A., Cambridge University Press, Cambridge, United Kingdom and New York, NY, USA, 239-287, 2001.

Feichter, J., Kjellström, E., Rodhe, H., Dentener, F., Lelieveld, J., and Roelofs, G.-J.: Simulation of the tropospheric sulfur cycle in a global climate model, Atmos. Environ., 30, 1693-1707, 1996.
Felzer, B., Reilly, J., Melillo, J., Kicklighter, D., Sarofim, M., Wang, C., Prinn, R., and Zhuang, Q.: Future effects of ozone on carbon sequestration and climate change policy using a global biogeochemical model, Clim. Change, 73, 345-373, 2005.

Fiore, A. M., Dentener, F. J., Wild, O., Cuvelier, C., Schultz, M. G., Hess, P., Textor, C., Schulz, M., Doherty, R. M., Horowitz, L. W., MacKenzie, I. A., Sanderson, M. G., Shindell, D. T., Stevenson, D. S., Szopa, S., Van Dingenen, R., Zeng, G., Atherton, C., Bergmann, D., Bey, I., Carmichael, G., Collins, W. J., Duncan, B. N., Faluvegi, G., Folberth, G., Gauss, M., Gong, S., Hauglustaine, D., Holloway, T., Isaksen, I. S. A., Jacob, D. J., Jonson, J. E., Kaminski, J. W., Keating, T. J., Lupu, A., Marmer, E., Montanaro, V., Park, R. J., Pitari, G., Pringle, K. J., Pyle, J. A., Schroeder, S., Vivanco, M. G., Wind, P., Wojcik, G., Wu, S., and Zuber, A.: Multimodel estimates of intercontinental sourcereceptor relationships for ozone pollution, J. Geophys. Res., 114, D04301, doi:10.1029/2008JD010816, 2009.

Flato, G., Marotzke, J., Abiodun, B., Braconnot, P., Chou, S. C., Collins, W., Cox, P., Driouech, F., Emori, S., Eyring, V., Forest, C., Gleckler, P., Guilyardi, E., Jakob, C., Kattsov, V., Reason, C., and Rummukaine, M.: Evaluation of climate models, in: Climate Change 2013: The Physical Science Basis. Contribution of Working Group I to the Fifth Assessment Report of the Intergovernmental Panel on Climate Change, edited by: Stocker, T. F., Qin, D., Plattner, G.-K., Tignor, M., Allen, S. K., Boschung, J., Nauels, A., Xia, Y., Bex V., and Midgley P. M., Cambridge University Press, Cambridge, United Kingdom and New York, NY, USA, 741-866, 2013.

Flemming, J., Inness, A., Flentje, H., Huijnen, V., Moinat, P., Schultz, M. G., and Stein, O.: Coupling global chemistry transport models to ECMWF's integrated forecast system, Geosci Model Dev., 2, 253-265, doi:10.5194/gmd-2-253-2009, 2009.

Flemming, J., Inness, A., Stein, O., Huijnen, V., Arteta, J., Elbern, H., and Woodhouse, M.: Updated development plan for C-IFS, MACC-II Deliverable D_57.1, 2012.

Forster, P. M., Thompson, D. W. J., Baldwin, M. P., Chipperfield, M. P., Dameris, M., Haigh, J. D., Karoly, D. J., Kushner, P. J., Randel, W. J., Rosenlof, K. H., Seidel, D. J., Solomon, S., Beig, G., Braesicke, P., Butchart, N., Gillett, N. P., Grise, K. M., Marsh, D. R., McLandress, C., Rao, T. N., Son, S.-W., Stenchikov, G. L., and Yoden, S.: Stratospheric changes and climate, in: Scientific Assessment of Ozone Depletion: 2010, Global Ozone Research and Monitoring Project-Report No. 52, 516 pp., World Meteorological Organization, Geneva, Switzerland, 2011.

Fortuin, J. P. F. and Kelder, H.: An ozone climatology based on ozonesonde and satellite measurements, J. Geophys. Res., 103, 31709-31734, 1998.

Ganzeveld, L. and Lelieveld, J.: Dry deposition parameterization in a chemistry general circulation model and its influence on the distribution of reactive trace gases, J. Geophys. Res., 100, 20999-21012, 1995.

Ganzeveld, L., Lelieveld, J., and Roelofs, G.-J.: A dry deposition parameterization for sulfur oxides in a chemistry and general circulation model, J. Geophys. Res., 103, 5679-5694, 1998.

Gery, M. W., Whitten, G. Z., Killus, J. P., and Dodge, M. C.: A photochemical kinetics mechanism for urban and regional scale computer modeling, J. Geophys. Res., 94, 12925-12956, 1989.

Gillett, N. P. and Thompson, D. W. J.: Simulation of recent Southern Hemisphere climate change, Science, 302, 273-275, 2003. 
Gong, S. L.: A parameterization of sea-salt aerosol source function for sub- and super-micron particles, Global Biogeochem. Cy., 17, 1097, doi:10.1029/2003GB002079, 2003.

Guelle, W., Balkanski, Y. J., Schulz, M., Dulac, F., and Monfray, P.: Wet deposition in a global size-dependent aerosol transport model: 1 . Comparison of a 1 year ${ }^{210} \mathrm{~Pb}$ simulation with ground measurements, J. Geophys. Res., 103, 11429-11445, 1998.

Guenther, A. B., Jiang, X., Heald, C. L., Sakulyanontvittaya, T., Duhl, T., Emmons, L. K., and Wang, X.: The Model of Emissions of Gases and Aerosols from Nature version 2.1 (MEGAN2.1): an extended and updated framework for modeling biogenic emissions, Geosci. Model Dev., 5, 1471-1492, doi:10.5194/gmd-51471-2012, 2012.

Hassler, B., Bodeker, G. E., and Dameris, M.: Technical Note: A new global database of trace gases and aerosols from multiple sources of high vertical resolution measurements, Atmos. Chem. Phys., 8, 5403-5421, doi:10.5194/acp-8-5403-2008, 2008.

Hassler, B., Bodeker, G. E., Cionni, I., and Dameris, M.: A vertically resolved, monthly mean, ozone database from 1979 to 2100 for constraining global climate model simulations, Int. J. Remote Sens., 30, 4009-4018, 2009.

Hazeleger, W., Severijns, C., Semmler, T., Ştefănescu, S., Yang, S., Wang, X., Wyser, K., Dutra, E., Baldasano, J. M., Bintanja, R., Bougeault, P., Caballero, R., Ekman, A. M. L., Christensen, J. H., van den Hurk, B., Jimenez, P., Jones, C., Kållberg, P., Koenigk, T., McGrath, R., Miranda, P., van Noije, T., Palmer, T., Parodi, J. A., Schmith, T., Selten, F., Storelvmo, T., Sterl, A., Tapamo, H., Vancoppenolle, M., Viterbo, P., and Willén, U.: EC-Earth: a seamless earth-system prediction approach in action, Bull. Am. Meteorol. Soc., 91, 1357-1363, 2010.

Hazeleger, W., Wang, X., Severijns, C., Ştefănescu, S., Bintanja, R., Sterl, A., Wyser, K., Semmler, T., Yang, S., van den Hurk, B., van Noije, T., van der Linden, E., and van der Wiel, K.: EC-Earth V2.2: description and validation of a new seamless earth system prediction model, Clim. Dynam., 39, 2611-2629, 2012.

Held, I. M. and Soden, B. J.: Robust responses of the hydrological cycle to global warming, J. Climate, 19, 5686-5699, 2006.

Holtslag, A. A. M. and Boville, B. A.: Local versus nonlocal boundary-layer diffusion in a global climate model, J. Climate, 6, 1825-1842, 1993.

Houweling, S., Dentener, F., and Lelieveld, J.: The impact of nonmethane hydrocarbon compounds on tropospheric photochemistry, J. Geophys. Res., 103, 10673-10696, 1998.

Hsu, J., Prather, M. J., and Wild, O.: Diagnosing the stratosphereto-troposphere flux of ozone in a chemistry transport model, J. Geophys. Res., 110, D19305, doi:10.1029/2005JD006045, 2005.

Huijnen, V., Williams, J., van Weele, M., van Noije, T., Krol, M., Dentener, F., Segers, A., Houweling, S., Peters, W., de Laat, J., Boersma, F., Bergamaschi, P., van Velthoven, P., Le Sager, P., Eskes, H., Alkemade, F., Scheele, R., Nédélec, P., and Pätz, H.-W.: The global chemistry transport model TM5: description and evaluation of the tropospheric chemistry version 3.0, Geosci. Model Dev., 3, 445-473, doi:10.5194/gmd-3-445-2010, 2010.

Huijnen, V., Williams, J. E., and Flemming, J.: Modeling global impacts of heterogeneous loss of $\mathrm{HO} 2$ on cloud droplets, ice particles and aerosols, Atmos. Chem. Phys. Discuss., 14, 8575-8632, doi:10.5194/acpd-14-8575-2014, 2014.
Jacobson, M. Z.: Global direct radiative forcing due to multicomponent anthropogenic and natural aerosols, J. Geophys. Res., 106, 1551-1568, 2001.

Jeuken, A., Veefkind, J. P., Dentener, F., Metzger, S., and Gonzalez, C. R.: Simulation of the aerosol optical depth over Europe for August 1997 and a comparison with observations, J. Geophys. Res., 106, 28295-28311, 2001.

Jung, T., Balsamo, G., Bechtold, P., Beljaars, A. C. M., Köhler, M., Miller, M. J., Morcrette, J.-J., Orr, A., Rodwell, M. J., and Tompkins, A. M.: The ECMWF model climate: Recent progress through improved physical parametrizations, Q. J. R. Meteorol. Soc., 136, 1145-1160, 2010.

Kinne, S., Schulz, M., Textor, C., Guibert, S., Balkanski, Y., Bauer, S. E., Berntsen, T., Berglen, T. F., Boucher, O., Chin, M., Collins, W., Dentener, F., Diehl, T., Easter, R., Feichter, J., Fillmore, D., Ghan, S., Ginoux, P., Gong, S., Grini, A., Hendricks, J., Herzog, M., Horowitz, L., Isaksen, I., Iversen, T., Kirkevåg, A., Kloster, S., Koch, D., Kristjansson, J. E., Krol, M., Lauer, A., Lamarque, J. F., Lesins, G., Liu, X., Lohmann, U., Montanaro, V., Myhre, G., Penner, J., Pitari, G., Reddy, S., Seland, O., Stier, P., Takemura, T., and Tie, X.: An AeroCom initial assessment - optical properties in aerosol component modules of global models, Atmos. Chem. Phys., 6, 1815-1834, doi:10.5194/acp-6-1815-2006, 2006.

Krol, M. C. and van Weele, M.: Implications of variations in photodissociation rates for global tropospheric chemistry, Atmos. Environ., 31, 1257-1273, 1997.

Krol, M. C., Houweling, S., Bregman, B., van den Broek, M., Segers, A., van Velthoven, P., Peters, W., Dentener, F., and Bergamaschi, P.: The two-way nested global chemistry-transport zoom model TM5: algorithm and applications, Atmos. Chem. Phys., 5, 417-432, doi:10.5194/acp-5-417-2005, 2005.

Lamarque, J.-F., Bond, T. C., Eyring, V., Granier, C., Heil, A., Klimont, Z., Lee, D., Liousse, C., Mieville, A., Owen, B., Schultz, M. G., Shindell, D., Smith, S. J., Stehfest, E., Van Aardenne, J., Cooper, O. R., Kainuma, M., Mahowald, N., McConnell, J. R., Naik, V., Riahi, K., and van Vuuren, D. P.: Historical (1850-2000) gridded anthropogenic and biomass burning emissions of reactive gases and aerosols: methodology and application, Atmos. Chem. Phys., 10, 7017-7039, doi:10.5194/acp10-7017-2010, 2010.

Lamarque, J.-F., Emmons, L. K., Hess, P. G., Kinnison, D. E., Tilmes, S., Vitt, F., Heald, C. L., Holland, E. A., Lauritzen, P. H., Neu, J., Orlando, J. J., Rasch, P. J., and Tyndall, G. K.: CAM-chem: description and evaluation of interactive atmospheric chemistry in the Community Earth System Model, Geosci. Model Dev., 5, 369-411, doi:10.5194/gmd-5-369-2012, 2012.

Lamarque, J.-F., Shindell, D. T., Josse, B., Young, P. J., Cionni, I., Eyring, V., Bergmann, D., Cameron-Smith, P., Collins, W. J., Doherty, R., Dalsoren, S., Faluvegi, G., Folberth, G., Ghan, S. J., Horowitz, L. W., Lee, Y. H., MacKenzie, I. A., Nagashima, T., Naik, V., Plummer, D., Righi, M., Rumbold, S. T., Schulz, M., Skeie, R. B., Stevenson, D. S., Strode, S., Sudo, K., Szopa, S., Voulgarakis, A., and Zeng, G.: The Atmospheric Chemistry and Climate Model Intercomparison Project (ACCMIP): overview and description of models, simulations and climate diagnostics, Geosci. Model Dev., 6, 179-206, doi:10.5194/gmd-6-179-2013, 2013a. 
Lamarque, J.-F., Dentener, F., McConnell, J., Ro, C.-U., Shaw, M., Vet, R., Bergmann, D., Cameron-Smith, P., Dalsoren, S., Doherty, R., Faluvegi, G., Ghan, S. J., Josse, B., Lee, Y. H., MacKenzie, I. A., Plummer, D., Shindell, D. T., Skeie, R. B., Stevenson, D. S., Strode, S., Zeng, G., Curran, M., Dahl-Jensen, D., Das, S., Fritzsche, D., and Nolan, M.: Multi-model mean nitrogen and sulfur deposition from the Atmospheric Chemistry and Climate Model Intercomparison Project (ACCMIP): evaluation of historical and projected future changes, Atmos. Chem. Phys., 13, 7997-8018, doi:10.5194/acp-13-7997-2013, 2013b.

Landgraf, J. and Crutzen, P. J.: An efficient method for online calculations of photolysis and heating rates, J. Atmos. Sci., 55, 863878, 1998.

Lelieveld, J. and Dentener, F. J.: What controls tropospheric ozone?, J. Geophys. Res., 105, 3531-3551, 2000.

Lelieveld, J., Peters, W., Dentener, F. J., and Krol, M. C.: Stability of tropospheric hydroxyl chemistry, J. Geophys. Res., 107, 4715, doi:10.1029/2002JD002272, 2002.

Lelieveld, J., Dentener, F. J., Peters, W., and Krol, M. C.: On the role of hydroxyl radicals in the self-cleansing capacity of the troposphere, Atmos. Chem. Phys., 4, 2337-2344, doi:10.5194/acp4-2337-2004, 2004.

Lenton, A., Codron, F., Bopp, L., Metzl, N., Cadule, P., Tagliabue, A., and Le Sommer, J.: Stratospheric ozone depletion reduces ocean carbon uptake and enhances ocean acidification, Geophys. Res. Lett., 36, L12606, doi:10.1029/2009GL038227, 2009.

Levy, H.: Normal atmosphere: Large radical and formaldehyde concentrations predicted, Science, 173, 141-143, 1971.

Louis, J.-F.: A parametric model of vertical eddy fluxes in the atmosphere, Bound.-Lay. Meteorol., 17, 187-202, 1979.

Maahs, H. G.: Kinetics and mechanisms of the oxidation of S(IV) by ozone in aqueous solution with particular reference to $\mathrm{SO}_{2}$ conversion in nonurban clouds, J. Geophys. Res., 88, 1072110732, 1983.

Martin, L. R. and Damschen, D. E.: Aqueous oxidation of sulfur dioxide by hydrogen peroxide at low pH, Atmos. Environ., 15, 1615-1621, 1981.

McLinden, C. A., Olsen, S. C., Hannegan, B., Wild, O., Prather, M. J., and Sundet, J.: Stratospheric ozone in 3-D models: A simple chemistry and the cross-tropopause flux, J. Geophys. Res., 105, 14653-14665, 2000.

Metzger, S., Dentener, F., Pandis, S., and Lelieveld, J.: Gas/aerosol partitioning: 1. A computationally efficient model, J. Geophys. Res., 107, 4312, 10.1029/2001JD001102, 2002.

Mickley, L. J., Jacob, D. J., Field, B. D., and Rind, D.: Climate response to the increase in tropospheric ozone since preindustrial times: A comparison between ozone and equivalent $\mathrm{CO}_{2}$ forcings, J. Geophys. Res., 109, D05106, doi:10.1029/2003JD003653, 2004.

Monahan, E. C. and Muircheartaigh, I.: Optimal power-law description of oceanic whitecap coverage dependence on wind speed, J. Phys. Oceanogr., 10, 2094-2099, 1980.

Morcrette, J.-J., Boucher, O., Jones, L., Salmond, D., Bechtold, P., Beljaars, A., Benedetti, A., Bonet, A., Kaiser, J. W., Razinger, M., Schulz, M., Serrar, S., Simmons, A. J., Sofiev, M., Suttie, M., Tompkins, A. M., and Untch, A.: Aerosol analysis and forecast in the European Centre for Medium-Range Weather Forecasts Integrated Forecast System: Forward modeling, J. Geophys. Res., 114, D06206, doi:10.1029/2008JD011235, 2009.
Myhre, G., Samset, B. H., Schulz, M., Balkanski, Y., Bauer, S., Berntsen, T. K., Bian, H., Bellouin, N., Chin, M., Diehl, T., Easter, R. C., Feichter, J., Ghan, S. J., Hauglustaine, D., Iversen, T., Kinne, S., Kirkevåg, A., Lamarque, J.-F., Lin, G., Liu, X., Lund, M. T., Luo, G., Ma, X., van Noije, T., Penner, J. E., Rasch, P. J., Ruiz, A., Seland, Ø., Skeie, R. B., Stier, P., Takemura, T., Tsigaridis, K., Wang, P., Wang, Z., Xu, L., Yu, H., Yu, F., Yoon, J.-H., Zhang, K., Zhang, H., and Zhou, C.: Radiative forcing of the direct aerosol effect from AeroCom Phase II simulations, Atmos. Chem. Phys., 13, 1853-1877, doi:10.5194/acp-13-18532013, 2013a.

Myhre, G., Shindell, D., Bréon, F.-M., Collins, W., Fuglestvedt, J., Huang, J., Koch, D., Lamarque, J.-F., Lee, D., Mendoza, B., Nakajima, T., Robock, A., Stephens, G., Takemura, T., and Zhan, H.: Anthropogenic and natural radiative forcing, in: Climate Change 2013: The Physical Science Basis. Contribution of Working Group I to the Fifth Assessment Report of the Intergovernmental Panel on Climate Change, edited by: Stocker, T. F., Qin, D., Plattner, G.-K., Tignor, M., Allen, S. K., Boschung, J., Nauels, A., Xia, Y., Bex, V., and Midgley P. M., Cambridge University Press, Cambridge, United Kingdom and New York, NY, USA, 659-740, 2013b.

Naik, V., Voulgarakis, A., Fiore, A. M., Horowitz, L. W., Lamarque, J.-F., Lin, M., Prather, M. J., Young, P. J., Bergmann, D., Cameron-Smith, P. J., Cionni, I., Collins, W. J., Dalsøren, S. B., Doherty, R., Eyring, V., Faluvegi, G., Folberth, G. A., Josse, B., Lee, Y. H., MacKenzie, I. A., Nagashima, T., van Noije, T. P. C., Plummer, D. A., Righi, M., Rumbold, S. T., Skeie, R., Shindell, D. T., Stevenson, D. S., Strode, S., Sudo, K., Szopa, S., and Zeng, G.: Preindustrial to present-day changes in tropospheric hydroxyl radical and methane lifetime from the Atmospheric Chemistry and Climate Model Intercomparison Project (ACCMIP), Atmos. Chem. Phys., 13, 5277-5298, doi:10.5194/acp-13-5277-2013, 2013.

Nair, S. K. and Peters, L. K.: Studies on non-precipitating cumulus cloud acidification, Atmos. Environ., 23, 1399-1423, 1989.

Olivié, D. J. L., van Velthoven, P. F. J., and Beljaars, A. C. M.: Evaluation of archived and off-line diagnosed vertical diffusion coefficients from ERA-40 with 222Rn simulations, Atmos. Chem. Phys., 4, 2313-2336, doi:10.5194/acp-4-2313-2004, 2004a.

Olivié, D. J. L., van Velthoven, P. F. J., Beljaars, A. C. M., and Kelder, H. M.: Comparison between archived and off-line diagnosed convective mass fluxes in the chemistry transport model TM3, J. Geophys. Res., 109, D11303, doi:10.1029/2003JD004036, 2004b.

Olivier, J., Peters, J., Granier, C., Pétron, G., Müller, J.-F., and Wallens, S.: Present and future surface emissions of atmospheric compounds, POET report \#2, EU project EVK2-1999-00011, 2003.

Olsen, M. A., Schoeberl, M. R., and Douglass, A. R.: Stratospheretroposphere exchange of mass and ozone, J. Geophys. Res., 109, D24114, doi:10.1029/2004JD005186, 2004.

Perlwitz, J., Pawson, S., Fogt, R. L., Nielsen, J. E., and Neff, W. D.: Impact of stratospheric ozone hole recovery on Antarctic climate, Geophys. Res. Lett., 35, L08714, doi:10.1029/2008GL033317, 2008.

Peters, W., Krol, M. C., Dlugokencky, E. J., Dentener, F. J., Bergamaschi, P., Dutton, G., van Velthoven, P., Miller, J. B., Bruhwiler, L., and Tans, P. P.: Toward regional-scale model- 
ing using the two-way nested global model TM5: Characterization of transport using $\mathrm{SF}_{6}$, J. Geophys. Res., 109, D19314, doi:10.1029/2004JD005020, 2004.

Peters, W., Krol, M. C., van der Werf, G. R., Houweling, S., Jones, C. D., Hughes, J., Schaefer, K., Masarie, K. A., Jacobson, A. R., Miller, J. B., Cho, C. H., Ramonet, M., Schmidt, M., Ciattaglia, L., Apadula, F., Heltai, D., Meinhardt, F., Di Sarra, A. G., Piacentino, S., Sferlazzo, D., Aalto, T., Hatakka, J., Ström, J., Haszpra, L., Meijer, H. A. J., van der Laan, S., Neubert, R. E. M., Jordan, A., Rodó, X., Morguí, J.-A., Vermeulen, A. T., Popa, E., Rozanski, K., Zimnoch, M., Manning, A. C., Leuenberger, M., Uglietti, C., Dolman, A. J., Ciais, P., Heimann, M., and Tans, P. P.: Seven years of recent European net terrestrial carbon dioxide exchange constrained by atmospheric observations, Glob. Change Biol., 16, 1317-1337, 2010.

Petzold, A., Ogren, J. A., Fiebig, M., Laj, P., Li, S.-M., Baltensperger, U., Holzer-Popp, T., Kinne, S., Pappalardo, G., Sugimoto, N., Wehrli, C., Wiedensohler, A., and Zhang, X.-Y.: Recommendations for reporting "black carbon" measurements, Atmos. Chem. Phys., 13, 8365-8379, doi:10.5194/acp-13-83652013, 2013.

Polvani, L. M., Waugh, D. W., Correa, G. J. P., and Son, S.-W.: Stratospheric ozone depletion: The main driver of twentiethcentury atmospheric circulation changes in the Southern Hemisphere, J. Climate, 24, 795-812, 2011.

Prather, M. J.: Numerical advection by conservation of secondorder moments, J. Geophys. Res., 91, 6671-6681, 1986.

Prather, M. J., Holmes, C. D., and Hsu, J.: Reactive greenhouse gas scenarios: Systematic exploration of uncertainties and the role of atmospheric chemistry, Geophys. Res. Lett., 39, L09803, doi:10.1029/2012GL051440, 2012.

Rasch, P. J., Feichter, J., Law, K., Mahowald, N., Penner, J., Benkovitz, C., Genthon, C., Giannakopoulos, C., Kasibhatla, P., Koch, D., Levy, H., Maki, T., Prather, M., Roberts, D. L., Roelofs, G.-J., Stevenson, D., Stockwell, Z., Taguchi, S., Kritz, M., Chipperfield, M., Baldocchi, D., McMurry, P., Barrie, L., Balkanski, Y., Chatfield, R., Kjellstrom, E., Lawrence, M., Lee, H. N., Lelieveld, J., Noone, K. J., Seinfeld, J., Stenchikov, G., Schwartz, S., Walcek, C., and Williamson, D.: A comparison of scavenging and deposition processes in global models: results from the WCRP Cambridge Workshop of 1995, Tellus B, 52, 1025-1056, 2000.

Roelofs, G.-J.: Aerosol and drop size dependent cloud chemistry, PhD thesis, Utrecht University, 1992.

Roelofs, G.-J. and Lelieveld, J.: Distribution and budget of $\mathrm{O}_{3}$ in the troposphere calculated with a chemistry general circulation model, J. Geophys. Res., 100, 20983-20998, 1995.

Russell, G. L. and Lerner, J. A.: A new finite-differencing scheme for the tracer transport equation, J. Appl. Meteorol., 20, 14831498, 1981.

Segers, A., van Velthoven, P., Bregman, B., and Krol, M.: On the computation of mass fluxes for Eulerian transport models from spectral meteorological fields, in: Proceedings of the International Conference on Computational Science, edited by: Sloot, P. M. A., Tan, C. J. K., Dongarra, J. J., and Hoekstra, A. G., 2124 April 2002, Amsterdam, Netherlands, Lecture Notes in Computer Science, 2330, Springer-Verlag, Berlin, Heidelberg, Germany, 767-776, 2002.
Seinfeld, J. H. and Pandis, S. N.: Atmospheric chemistry and physics: from air pollution to climate change, 2nd Edn., John Wiley \& Sons, Inc., Hoboken, New Jersey, USA, 2006.

Shindell, D. T., Faluvegi, G., Lacis, A., Hansen, J., Ruedy, R., and Aguilar, E.: Role of tropospheric ozone increases in 20th-century climate change, J. Geophys. Res., 111, D08302, doi:10.1029/2005JD006348, 2006a.

Shindell, D. T., Faluvegi, G., Stevenson, D. S., Krol, M. C., Emmons, L. K., Lamarque, J.-F., Pétron, G., Dentener, F. J., Ellingsen, K., Schultz, M. G., Wild, O., Amann, M., Atherton, C. S., Bergmann, D. J., Bey, I., Butler, T., Cofala, J., Collins, W. J., Derwent, R. G., Doherty, R. M., Drevet, J., Eskes, H. J., Fiore, A. M., Gauss, M., Hauglustaine, D. A., Horowitz, L. W., Isaksen, I. S. A., Lawrence, M. G., Montanaro, V., Müller, J.-F., Pitari, G., Prather, M. J., Pyle, J. A., Rast, S., Rodriguez, J. M., Sanderson, M. G., Savage, N. H., Strahan, S. E., Sudo, K., Szopa, S., Unger, N., van Noije, T. P. C., and Zeng, G.: Multimodel simulations of carbon monoxide: Comparison with observations and projected near-future changes, J. Geophys. Res., 111, D19306, doi:10.1029/2006JD007100, 2006b.

Shindell, D. T., Faluvegi, G., Unger, N., Aguilar, E., Schmidt, G. A., Koch, D. M., Bauer, S. E., and Miller, R. L.: Simulations of preindustrial, present-day, and 2100 conditions in the NASA GISS composition and climate model G-PUCCINI, Atmos. Chem. Phys., 6, 4427-4459, doi:10.5194/acp-6-4427-2006, 2006c.

Shindell, D. T., Faluvegi, G., Koch, D. M., Schmidt, G. A., Unger, N., and Bauer, S. E.: Improved attibution of climate forcing to emissions, Science, 326, 716-718, 2009.

Shindell, D. T., Lamarque, J.-F., Schulz, M., Flanner, M., Jiao, C., Chin, M., Young, P. J., Lee, Y. H., Rotstayn, L., Mahowald, N., Milly, G., Faluvegi, G., Balkanski, Y., Collins, W. J., Conley, A. J., Dalsoren, S., Easter, R., Ghan, S., Horowitz, L., Liu, X., Myhre, G., Nagashima, T., Naik, V., Rumbold, S. T., Skeie, R., Sudo, K., Szopa, S., Takemura, T., Voulgarakis, A., Yoon, J.-H., and Lo, F.: Radiative forcing in the ACCMIP historical and future climate simulations, Atmos. Chem. Phys., 13, 2939-2974, doi:10.5194/acp-13-2939-2013, 2013.

Sigmond, M., Reader, M. C., Fyfe, J. C., and Gillett, N. P.: Drivers of past and future Southern Ocean change: Stratospheric ozone versus greenhouse gas impacts, Geophys. Res. Lett., 38, L12601, doi:10.1029/2011GL047120, 2011.

Simpson, D., Benedictow, A., Berge, H., Bergström, R., Emberson, L. D., Fagerli, H., Flechard, C. R., Hayman, G. D., Gauss, M., Jonson, J. E., Jenkin, M. E., Nyíri, A., Richter, C., Semeena, V. S., Tsyro, S., Tuovinen, J.-P., Valdebenito, Á., and Wind, P.: The EMEP MSC-W chemical transport model - technical description, Atmos. Chem. Phys., 12, 7825-7865, doi:10.5194/acp-127825-2012, 2012.

Sitch, S., Cox, P. M., Collins, W. J., and Huntingford, C.: Indirect radiative forcing of climate change through ozone effects on the land-carbon sink, Nature, 448, 791-794, 2007.

Slinn, S. A. and Slinn, W. G. N.: Predictions for particle deposition on natural waters, Atmos. Environ., 14, 1013-1016, 1980.

Slinn, W. G. N.: Dry deposition and resuspension of aerosol particles - a new look at some old problems, in: AtmosphereSurface Exchange of Particulate and Gaseous Pollutants, edited by: Engelmann, R. J. and Sehmel, G. A., CONF-740921, Na- 
tional Technical Information Service, Springfield, VA, USA, 140, 1976.

Smith, B., Prentice, I. C., and Sykes, M. T.: Representation of vegetation dynamics in the modelling of terrestrial ecosystems: comparing two contrasting approaches within European climate space, Global Ecol. Biogeogr., 10, 621-637, 2001.

Son, S.-W., Polvani, L. M., Waugh, D. W., Akiyoshi, H., Garcia, R., Kinnison, D., Pawson, S., Rozanov, E., Shepherd, T. G., and Shibata, K.: The impact of stratospheric ozone recovery on the Southern Hemisphere westerly jet, Science, 320, 1486-1489, 2008.

Spiro, P. A., Jacob, D. J., and Logan, J. A.: Global inventory of sulfur emissions with $1^{\circ} \times 1^{\circ}$ resolution, J. Geophys. Res., 97, 6023-6036, 1992.

Spivakovsky, C. M., Logan, J. A., Montzka, S. A., Balkanski, Y. J., Foreman-Fowler, M., Jones, D. B. A., Horowitz, L. W., Fusco, A. C., Brenninkmeijer, C. A. M., Prather, M. J., Wofsy, S. C., and McElroy, M. B.: Three-dimensional climatological distribution of tropospheric $\mathrm{OH}$ : Update and evaluation, J. Geophys. Res., 105, 8931-8980, 2000.

Stevenson, D. S., Dentener, F. J., Schultz, M. G., Ellingsen, K. van Noije, T. P. C., Wild, O., Zeng, G., Amann, M., Atherton, C. S., Bell, N., Bergmann, D. J., Bey, I., Butler, T., Cofala, J., Collins, W. J., Derwent, R. G., Doherty, R. M., Drevet, J., Eskes, H. J., Fiore, A. M., Gauss, M., Hauglustaine, D. A., Horowitz, L. W., Isaksen, I. S. A., Krol, M. C., Lamarque, J.-F., Lawrence, M. G., Montanaro, V., Müller, J.-F., Pitari, G., Prather, M. J., Pyle, J. A., Rast, S., Rodriguez, J. M., Sanderson, M. G., Savage, N. H., Shindell, D. T., Strahan, S. E., Sudo, K., and Szopa, S.: Multimodel ensemble simulations of present-day and near-future tropospheric ozone, J. Geophys. Res., 111, D08301, doi:10.1029/2005JD006338, 2006.

Stevenson, D. S., Young, P. J., Naik, V., Lamarque, J.-F., Shindell, D. T., Voulgarakis, A., Skeie, R. B., Dalsoren, S. B., Myhre, G., Berntsen, T. K., Folberth, G. A., Rumbold, S. T., Collins, W. J., MacKenzie, I. A., Doherty, R. M., Zeng, G., van Noije, T. P. C., Strunk, A., Bergmann, D., Cameron-Smith, P., Plummer, D. A., Strode, S. A., Horowitz, L., Lee, Y. H., Szopa, S., Sudo, K., Nagashima, T., Josse, B., Cionni, I., Righi, M., Eyring, V., Conley, A., Bowman, K. W., Wild, O., and Archibald, A.: Tropospheric ozone changes, radiative forcing and attribution to emissions in the Atmospheric Chemistry and Climate Model Intercomparison Project (ACCMIP), Atmos. Chem. Phys., 13, 3063-3085, doi:10.5194/acp-13-3063-2013, 2013.

Taguchi, S., Iida, T., and Moriizumi, J.: Evaluation of the atmospheric transport model NIRE-CTM-96 by using measured radon-222 concentrations, Tellus B, 54, 250-268, 2002.

Taylor, K. E., Stouffer, R. J., and Meehl, G. A.: An overview of CMIP5 and the experiment design, Bull. Amer. Meteor. Soc., 93, 485-498, 2012.

Tegen, I., Harrison, S. P., Kohfeld, K., Prentice, I. C., Coe, M., and Heimann, M.: Impact of vegetation and preferential source areas on global dust aerosol: Results from a model study, J. Geophys. Res., 107, 4576, doi:10.1029/2001JD000963, 2002.

Textor, C., Schulz, M., Guibert, S., Kinne, S., Balkanski, Y., Bauer, S., Berntsen, T., Berglen, T., Boucher, O., Chin, M., Dentener, F., Diehl, T., Easter, R., Feichter, H., Fillmore, D., Ghan, S., Ginoux, P., Gong, S., Grini, A., Hendricks, J., Horowitz, L., Huang, P., Isaksen, I., Iversen, I., Kloster, S., Koch, D., Kirkevåg, A., Krist- jansson, J. E., Krol, M., Lauer, A., Lamarque, J. F., Liu, X., Montanaro, V., Myhre, G., Penner, J., Pitari, G., Reddy, S., Seland, Ø., Stier, P., Takemura, T., and Tie, X.: Analysis and quantification of the diversities of aerosol life cycles within AeroCom, Atmos. Chem. Phys., 6, 1777-1813, doi:10.5194/acp-6-1777-2006, 2006.

Textor, C., Schulz, M., Guibert, S., Kinne, S., Balkanski, Y., Bauer, S., Berntsen, T., Berglen, T., Boucher, O., Chin, M., Dentener, F., Diehl, T., Feichter, J., Fillmore, D., Ginoux, P., Gong, S., Grini, A., Hendricks, J., Horowitz, L., Huang, P., Isaksen, I. S. A., Iversen, T., Kloster, S., Koch, D., Kirkevåg, A., Kristjansson, J. E., Krol, M., Lauer, A., Lamarque, J. F., Liu, X., Montanaro, V., Myhre, G., Penner, J. E., Pitari, G., Reddy, M. S., Seland, Ø., Stier, P., Takemura, T., and Tie, X.: The effect of harmonized emissions on aerosol properties in global models an AeroCom experiment, Atmos. Chem. Phys., 7, 4489-4501, doi:10.5194/acp-7-4489-2007, 2007.

Thomson, A. M., Calvin, K. V., Smith, S. J., Kyle, G. P., Volke, A., Patel, P., Delgado-Arias, S., Bond-Lamberty, B., Wise, M. A., Clarke, L. E., and Edmonds, J. A.: RCP4.5: a pathway for stabilization of radiative forcing by 2100 , Climatic Change, 109 , 77-94, doi:10.1007/s10584-011-0151-4, 2011.

Tian, B., Fetzer, E. J., Kahn, B. H., Teixeira, J., Manning, E., and Hearty, T.: Evaluating CMIP5 Models using AIRS tropospheric air temperature and specific mumidity climatology, J. Geophys. Res., 118, 114-134, 2013.

Tiedtke, M.: A comprehensive mass flux scheme for cumulus parameterization in large-scale models, Mon. Weather Rev., 117, 1779-1800, 1989.

Tsigaridis, K., Daskalakis, N., Kanakidou, M., Adams, P. J., Artaxo, P., Bahadur, R., Balkanski, Y., Bauer, S. E., Bellouin, N., Benedetti, A., Bergman, T., Berntsen, T. K., Beukes, J. P., Bian, H., Carslaw, K. S., Chin, M., Curci, G., Diehl, T., Easter, R. C., Ghan, S. J., Gong, S. L., Hodzic, A., Hoyle, C. R., Iversen, T., Jathar, S., Jimenez, J. L., Kaiser, J. W., Kirkevåg, A., Koch, D., Kokkola, H., Lee, Y. H., Lin, G., Liu, X., Luo, G., Ma, X., Mann, G. W., Mihalopoulos, N., Morcrette, J.-J., Müller, J.-F., Myhre, G., Myriokefalitakis, S., Ng, S., O’Donnell, D., Penner, J. E., Pozzoli, L., Pringle, K. J., Russell, L. M., Schulz, M., Sciare, J., Seland, Ø., Shindell, D. T., Sillman, S., Skeie, R. B., Spracklen, D., Stavrakou, T., Steenrod, S. D., Takemura, T., Tiitta, P., Tilmes, S., Tost, H., van Noije, T., van Zyl, P. G., von Salzen, K., Yu, F., Wang, Z., Wang, Z., Zaveri, R. A., Zhang, H., Zhang, K., Zhang, Q., and Zhang, X.: The AeroCom evaluation and intercomparison of organic aerosol in global models, Atmos. Chem. Phys., 14, 10845-10895, doi:10.5194/acp-1410845-2014, 2014.

US Standard Atmosphere: 1976, US Government Printing Office, Washington, DC, 1976.

Valcke, S.: The OASIS3 coupler: a European climate modelling community software, Geosci. Model Dev., 6, 373-388, doi:10.5194/gmd-6-373-2013, 2013.

van $\operatorname{der}$ A, R. J., Allaart, M. A. F., and Eskes, H. J.: Multi sensor reanalysis of total ozone, Atmos. Chem. Phys., 10, 11277-11294, doi:10.5194/acp-10-11277-2010, 2010.

Van Noije, T. P. C., Eskes, H. J., van Weele, M., and van Velthoven, P. F. J.: Implications of the enhanced Brewer-Dobson circulation in European Centre for Medium-Range Weather Forecasts reanalysis ERA-40 for the stratosphere-troposphere exchange of 
ozone in global chemistry transport models, J. Geophys. Res., 109, D19308, doi:10.1029/2004JD004586, 2004.

Van Noije, T. P. C., Segers, A. J., and van Velthoven, P. F. J.: Time series of the stratosphere-troposphere exchange of ozone simulated with reanalyzed and operational forecast data, J. Geophys. Res., 111, D03301, doi:10.1029/2005JD006081, 2006.

Van Vuuren, D. P., Edmonds, J., Kainuma, M., Riahi, K., Thomson, A., Hibbard, K., Hurtt, G. C., Kram, T., Krey, V., Lamarque, J.F., Masui, T., Meinshausen, M., Nakicenovic, N., Smith, S. J., and Rose, S. K.: The representative concentration pathways: an overview, Climatic Change, 109, 5-31, 2011.

Vignati, E., Wilson, J., and Stier, P.: M7: An efficient size-resolved aerosol microphysics module for large-scale aerosol transport models, J. Geophys. Res., 109, D22202, doi:10.1029/2003JD004485, 2004.

Vignati, E., Karl, M., Krol, M., Wilson, J., Stier, P., and Cavalli, F.: Sources of uncertainties in modelling black carbon at the global scale, Atmos. Chem. Phys., 10, 2595-2611, doi:10.5194/acp-102595-2010, 2010a.

Vignati, E., Facchini, M. C., Rinaldi, M., Scannell, C., Ceburnis, D., Sciare, J., Kanakidou, M., Myriokefalitakis, S., Dentener, F., and O'Dowd, C. D.: Global scale emission and distribution of seaspray aerosol: Sea-salt and organic enrichment, Atmos. Environ., 44, 670-677, 2010b.

Vogelezang, D. H. P. and Holtslag, A. A. M.: Evaluation and model impacts of alternative boundary-layer height formulations, Bound.-Lay. Meteorol., 81, 245-269, 1996.

von Hardenberg, J., Vozella, L., Tomasi, C., Vitale, V., Lupi, A., Mazzola, M., van Noije, T. P. C., Strunk, A., and Provenzale, A.: Aerosol optical depth over the Arctic: a comparison of ECHAMHAM and TM5 with ground-based, satellite and reanalysis data, Atmos. Chem. Phys., 12, 6953-6967, doi:10.5194/acp-12-69532012, 2012.

Weiss, M., Miller, P., van den Hurk, B., van Noije, T., Ştefănescu, S., Haarsma, R., van Ulft, L. H., Hazeleger, W., Le Sager, P., Smith, B., and Schurges, G.: Contribution of dynamic vegetation phenology to decadal climate predictability, J. Climate, doi:10.1175/JCLI-D-13-00684.1, in press, 2014.

Wesely, M. L.: Parameterization of surface resistances to gaseous dry deposition in regional-scale numerical models, Atmos. Environ., 23, 1293-1304, 1989.

Wild, O. and Prather, M. J.: Global tropospheric ozone modeling: Quantifying errors due to grid resolution, J. Geophys. Res., 111, D11305, doi:10.1029/2005JD006605, 2006.

Williams, A. G., Chambers, S., Zahorowski, W., Crawford, J., Matsumoto, K., and Uematsu, M.: Estimating the Asian radon flux density and its latitudinal gradient in winter using ground-based radon observations at Sado Island, Tellus B, 61, 732-746, 2009.
Williams, A. G., Zahorowski, W., Chambers, S. D., and Griffiths, A.: The vertical distribution of radon in clear and cloudy daytime terrestrial boundary layers, J. Atmos. Sci., 68, 155-174, 2011.

Williams, J. E., Landgraf, J., Bregman, A., and Walter, H. H.: A modified band approach for the accurate calculation of online photolysis rates in stratospheric-tropospheric Chemical Transport Models, Atmos. Chem. Phys., 6, 4137-4161, doi:10.5194/acp-6-4137-2006, 2006.

Williams, J. E., Strunk, A., Huijnen, V., and van Weele, M.: The application of the Modified Band Approach for the calculation of on-line photodissociation rate constants in TM5: implications for oxidative capacity, Geosci. Model Dev., 5, 15-35, doi:10.5194/gmd-5-15-2012, 2012.

Yienger, J. J. and Levy II, H.: Empirical model of global soilbiogenic $\mathrm{NO}_{\mathrm{x}}$ emissions, J. Geophys. Res., 100, 11447-11464, 1995.

Young, P. J., Archibald, A. T., Bowman, K. W., Lamarque, J.-F., Naik, V., Stevenson, D. S., Tilmes, S., Voulgarakis, A., Wild, O., Bergmann, D., Cameron-Smith, P., Cionni, I., Collins, W. J., Dalsøren, S. B., Doherty, R. M., Eyring, V., Faluvegi, G., Horowitz, L. W., Josse, B., Lee, Y. H., MacKenzie, I. A., Nagashima, T., Plummer, D. A., Righi, M., Rumbold, S. T., Skeie, R. B., Shindell, D. T., Strode, S. A., Sudo, K., Szopa, S., and Zeng, G.: Preindustrial to end 21 st century projections of tropospheric ozone from the Atmospheric Chemistry and Climate Model Intercomparison Project (ACCMIP), Atmos. Chem. Phys., 13, 2063 2090, doi:10.5194/acp-13-2063-2013, 2013.

Zahorowski, W., Chambers, S. D., and Henderson-Sellers, A.: Ground based radon-222 observations and their application to atmospheric studies, J. Environ. Radioact., 76, 3-33, 2004.

Zahorowski, W., Chambers, S., Wang, T., Kang, C.-H., Uno, I., Poon, S., Oh, S.-N., Werczynski, S., Kim, J., and HendersonSellers, A.: Radon-222 in boundary layer and free tropospheric continental outflow events at three ACE-Asia sites, Tellus B, 57, 124-140, 2005.

Zhang, K., Wan, H., Zhang, M., and Wang, B.: Evaluation of the atmospheric transport in a GCM using radon measurements: sensitivity to cumulus convection parameterization, Atmos. Chem. Phys., 8, 2811-2832, doi:10.5194/acp-8-2811-2008, 2008.

Zhang, K., Feichter, J., Kazil, J., Wan, H., Zhuo, W., Griffiths, A. D., Sartorius, H., Zahorowski, W., Ramonet, M., Schmidt, M., Yver, C., Neubert, R. E. M., and Brunke, E.-G.: Radon activity in the lower troposphere and its impact on ionization rate: a global estimate using different radon emissions, Atmos. Chem. Phys., 11, 7817-7838, doi:10.5194/acp-11-7817-2011, 2011.

Zhang, Y.: Online-coupled meteorology and chemistry models: history, current status, and outlook, Atmos. Chem. Phys., 8, 28952932, doi:10.5194/acp-8-2895-2008, 2008. 